\title{
الاستدلال الفراغي لدى طلبة المرحلة الإعدادية
}

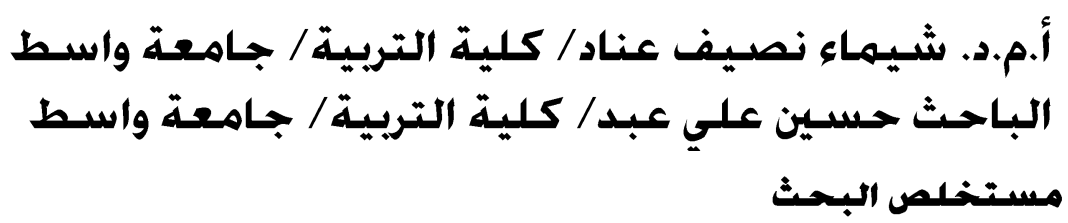

يهاف البحث إلى تعرف الاستدلال الفراغي لدى طلبة الصف الخامس الإعدادي. ودلالة الفروق في الاستدلال الفراغي تبعاً لمتغيري

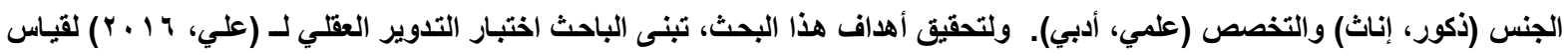

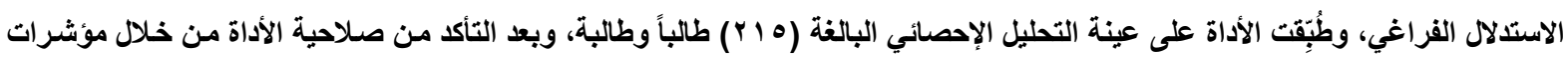

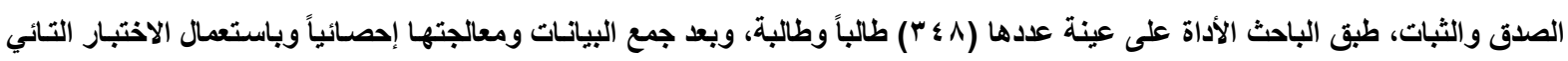
لعينة واحدة، والاختبار التائي لعينتين، وتحليل التباين، ومربع كاي، ومعامل ارتباط بيرسون، توصل الباحث إلى النتائج الآتية ا - يمتلك طلبة المرحلة الإعدادية القدرة على الاستدلال الفراغي .

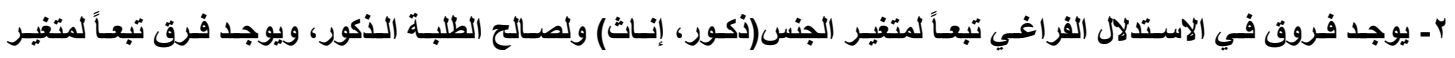
التخصص(علمي، أدبي) ولصالح طلبة التخصص العلمي.

وفي ضوء النتائج التي تم التوصل إليها واستكمالاً للبحث أوصى الباحث بمجموعة من التوصيات والمقترحات للأبحاث المستقبلة .

\section{ABSTRACT}

(Spatial reasoning of Preparatory stage students)

The research aims to identify :

1. Spatial reasoning of fifth preparatory stage students .

r.significance of differences in Spatial reasoning according to the variable of sex (males, females) and specialty (scientific, literary) .

To achieve the aims, of this research, the researcher has adopted the test of mental rotation of $(A l i, Y+17)$ To measure spatial reasoning, The two tool were applied on the sample of statistical analysis which includes $\left(r^{\circ} \bullet\right)$ male and female students, After verifying the validity of the two tool through validity and stability indicators, the researcher has applied the two tool on a sample Which includes $(r \leqslant \wedge)$ male and female students, after collecting data and processing them statistically by using $T$. test for one sample ,and T. test for two samples, analysis of variance, and Kais square, and Pearson correlation coefficient.

The researcher has reached to the following results :

1. The Primary stage students have the ability of Spatial reasoning .

$r$. There is difference in the Spatial reasoning according to the variable of sex (males, females) for the benefit specialty of female students and there is a difference according to the variable of specialty (scientific, literary) for the benefit of scientific specialty.

In the light of the results which the researcher has reached to and as a completion of the research, the researcher has recommended some recommendations and suggestions for further researches .

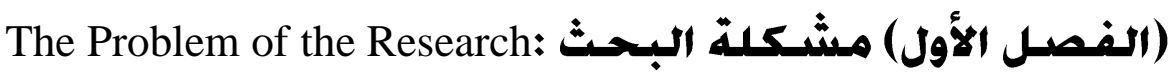

يعد الاسـدلال الفر اغي و احداً من أصسعب القدرات العقلية؛ وذلك بسبب الطبيعـة المعقدة لـه، فـالأفراد

الذين يو اجهون صعوبة في المهمات التي تتطلب استدلالاً فر اغياً سوف يفشلون في انجاز تلك المهــات، وكما إنهم بحاجة إلى العديد من التوجيهات التي تساعدهم على ذلك، فقد يواجه الأفراد الذين يمتلكون استدلالاً فراغيـاً أقل من الآخرين صعوبة في عملية تتسيق الأثاث بشكل مناسب وملائم كما قد يلجئون إلى طلب المسـاعدة من

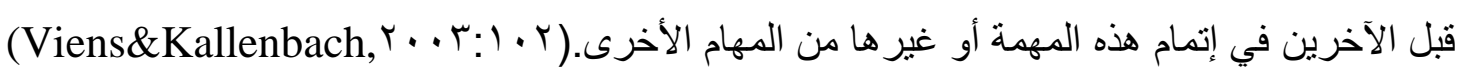


وان المشكلة التي تطفو على السطح هو إن العالم من حولنا ليس منظما بصورة تجعل من الاستدلال

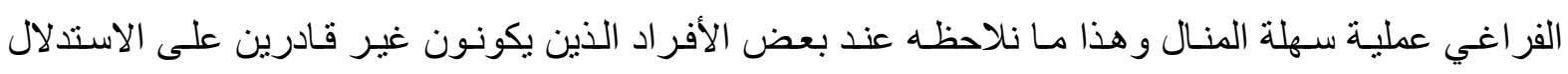
فر اغياً، لذا نجد من يعانون من نقص في هذا النوع من القرات الفر اغية يجدون صعوبة في التكيف مـع البيئات

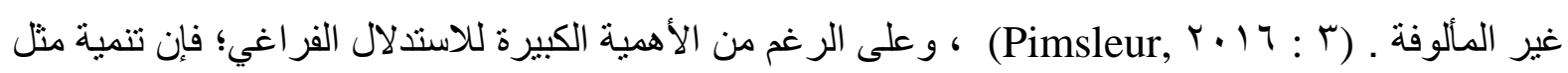
هذه القدرة تعد من الأمور التي تكاد تكون مفقودة في أنظمتنا التعليمية، فقد أنثار تقرير(المجلس الوطني للبحوث

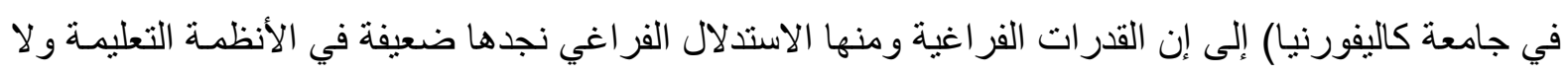

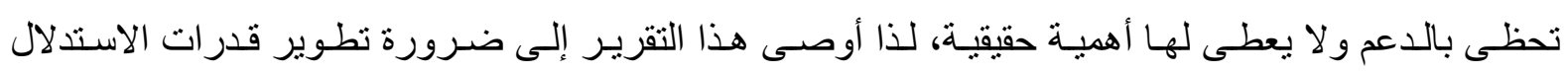
الفر اغي في كل المنـاهج الدراسية، وان قلـة الاهتمـام بالاستدلال الفر اغي لا يعمل فقط على تقليل نسبة انجاز المتعلمين في العلوم فحسب بل يعد هذا الأمر بمثابة حاجز يعيق عملية التعرف والتشخيص للطلبة الموهوبين

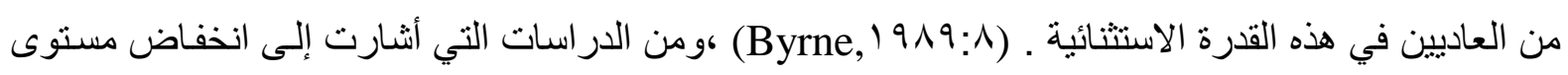

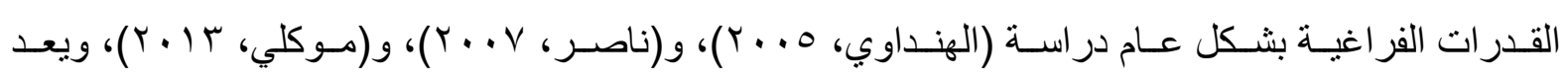
الاستدلال الفر اغي من القدرات التي لها علاقة بأداء الطلبة في مجال تدريس العلوم و عادة مـا يعاني الطلبة فيها

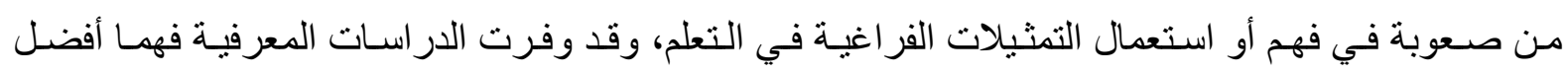

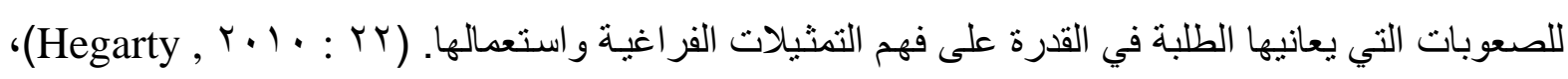
وبناء على ما تم عرضده من در اسات سابقة وآر اء تتعلق بضعف الطلبة في الاستدلال الفر اغي؛ لذا فإن مشكلة

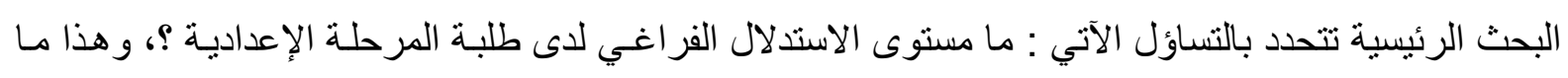
سيحاول البحث الإجابة عنه.

أهمية البحسث The importance of the Research

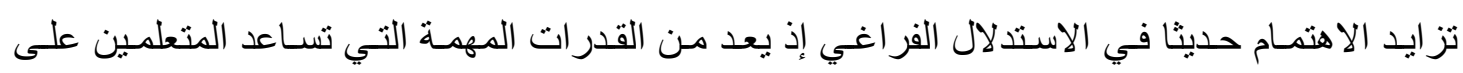

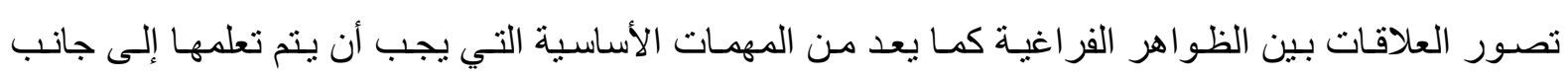

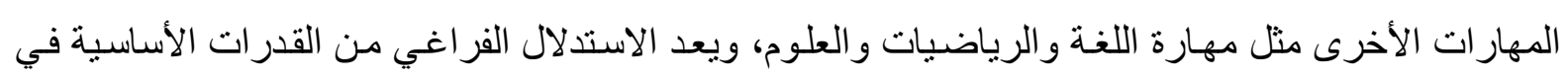
مختلف تفاعلاتتـا اليوميـة مـع العـالم كالقدرة على إدر الك رسم الخر ائط على الانترنيت وتحديد موقع السبارة

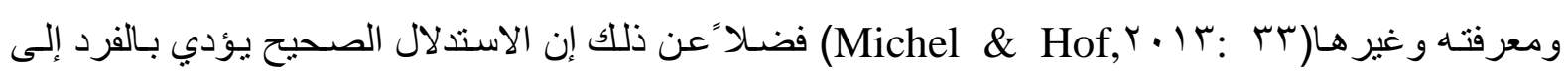

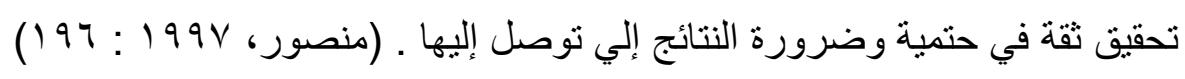

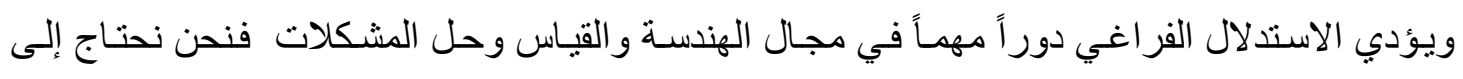
التنقل في العـالم الفيزيائي من خـلال ثلاثتة أبعاد، ونحن بحاجـة إلى الاستـدلال الفر اغي في مجـال التكنولوجيا و الرياضيات و العلوم الأخرى إذ نحتاج في تلك المجالات إلى وجود مهار ات فر اغية قوية للتمكن منها إذ أثنارت

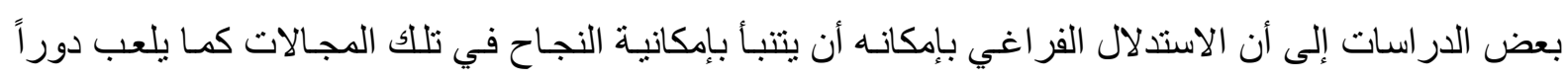
مهماً في العديد من الفنون . 
(Bruce, r r ميعد الاستدلال الفر اغي من القدرات المهمة لحل الكثير من المشكلات في

المجالات العلمية لما له من أهمية تطبيقية كبيرة فنجد لـه أهمية في علم الأحيـاء إذ استععل كل من واطسون

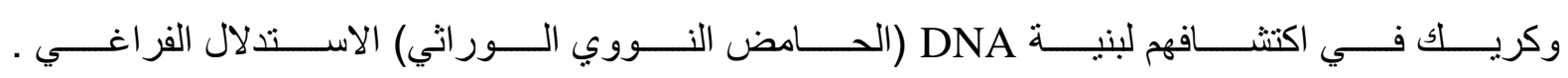

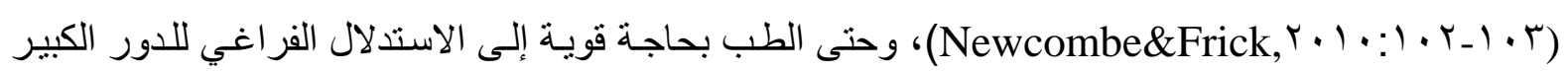
الذي يؤديه في هذه المجالات، كما انه يلعب دوراً أساسياً في مناهج التعليم فعلى سبيل المنتال در اسـة الكيمياء تتطلب من الطلبـة فهم البنية الفر اغيـة للأوزان الجزئية، وكذللك دراسـة الفيزيـاء فمثنلا النشـاط الفيزيـئي و الذي فئي

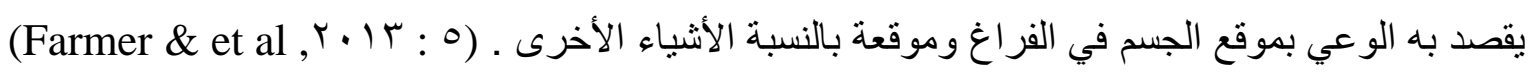
ومما يدل على الاهتمام بالاستدلال الفر اغي الوثيقة التي أصدر ها المجلس القومي لمعلمي الرياضيات

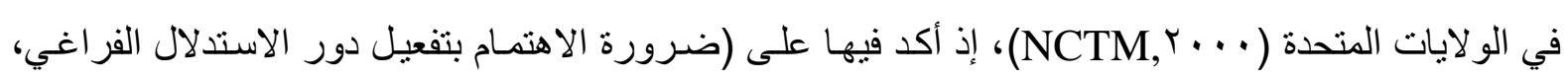

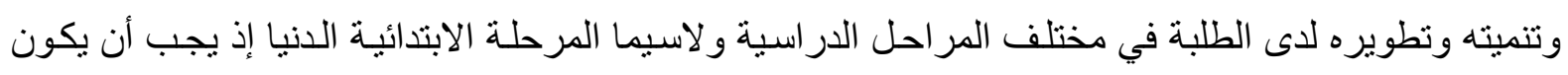

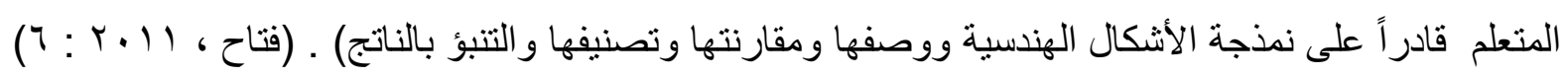
فالاستدلال الفر اغي مطلب ضـروري في أعمال التكنولوجيا و التصميم إذ يستعمل في تلك الأعمـال الرسومات و المخططات والتصميم كما أنه ضروري لبعض الفروع من العلم والتكنولوجيـا حيث يوجد تفاعل التهل بين المكونـات ذات الثناثيـة الأبعاد، ويستعمل كذلك في المجال العسكري والأمني حيث يتطلب التعرف على ولى في الخر ائط والمخططات للشـار ع وفهم الاتجاهـات التي تظهر في الخريطة ووصف المسـار ات، إن أسئلة القدرة الفر اغية تتضمن قدرة الفرد على الاحتفاظ بالأشكال عقلياً لتحديد الأنماط، و عمل استدلال منطقي حولها، ومـا لم

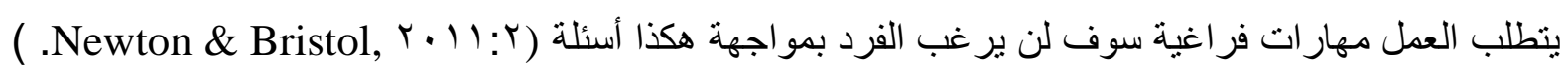
وللاستدلال الفر اغي أهمية بالغة في كثير من الوظائف التي تتطلب من الفرد أن يتخيل مـا يحدث لثيء معين إذا ما استدار هذا الثيء، أو إذا ما انقلب بطريقة معينة، كالفن المعدـاري، وفن التفصيل، والرسم عامـة،

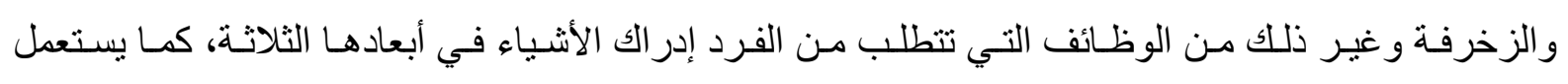
الاستدلال الفر اغي للوصول إلى كل العلاقات المحتملة بين مجموعة الأشياء؛ وذلك باستعمال علاقة فر عيـة أو

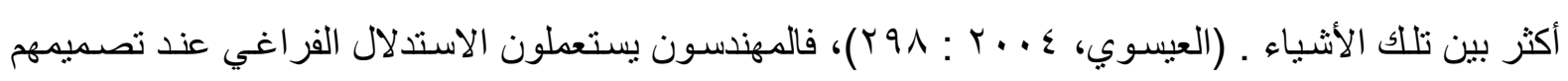

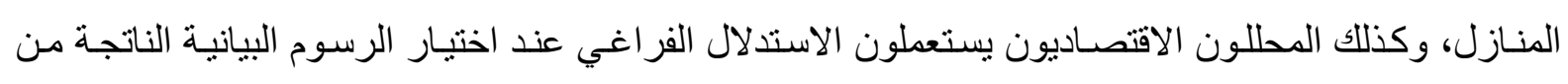

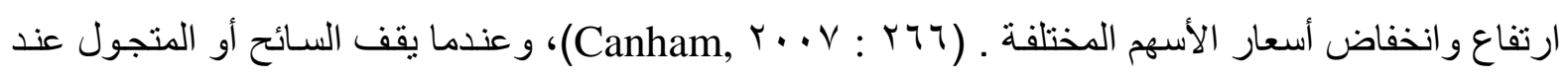

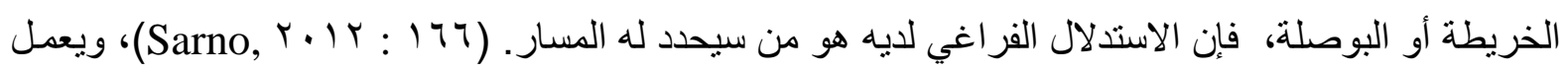
الاستـلال الفر اغـي على حل المشكلات من خـلال إدارة البيانـات أو المعلومـات المعطـاة وترجمتهـا وتحليلهـا و لاسيما المعقدة منها ويتضمن الاستدلال الفر اغي موقع وحركة الأشياء أو الأشخاص فيزيائياً أو عقلياً؛ وتبعاً

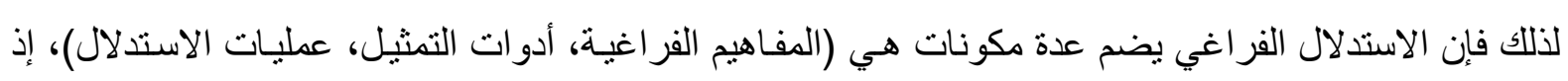

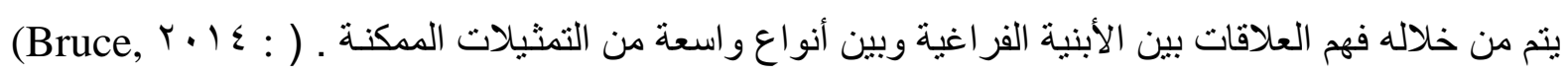


وكمـا يعـد الاسـتدلال الفراغي مـن القـدرات العقليـة الحيويـة للإنسـان التـي تظهر مـن خـلال أفكـاره

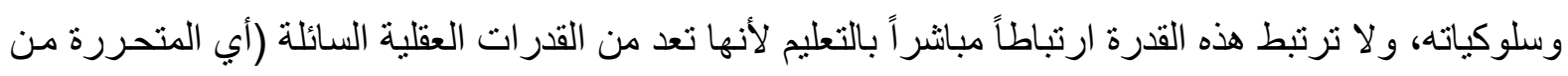

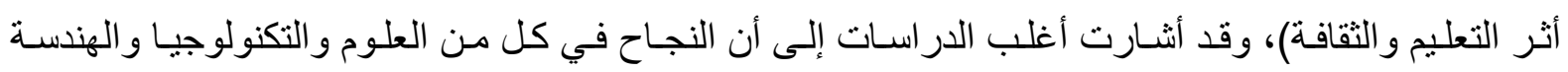
و الرياضيات يرتبط بهذه القدر ؛إذ إنها تعمل على تدعيم وتطوير نوع خاص من التفكير وهو التفكير الفراغي .

(Davis, r. 10:0)

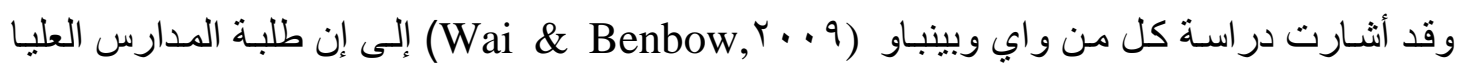
الذين اظهروا مهار ات فر اغية قوية هم أكثر متعة وتفضيلاً ونجاحاً في الرياضيات، وتبعاً لذللك فقد أشـارت هذه

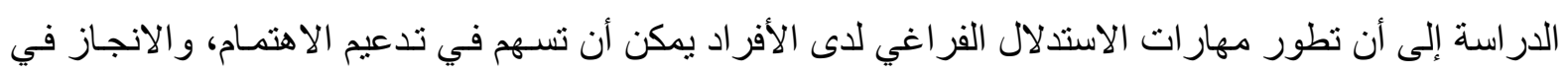

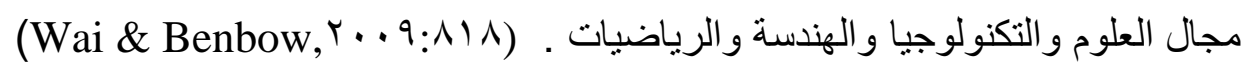

ويعد الاستدلال الفراغي من الأدوات الرئيسة في نشكيل المعرفة ذات المنطق السليم، وان اغلب الأفراد

عادةً يقومون بحل المشكلات المعقة ذات العلاقة بالفر اغ أو الفضاء من مثل تصميم المباني وتجميع المركبات من عدة أجز اء، وحزم الأمتعـة الخاصـة بهم، ويعد الاستدلال حول حركه الأشياء مـن الموضو عات الفرعية

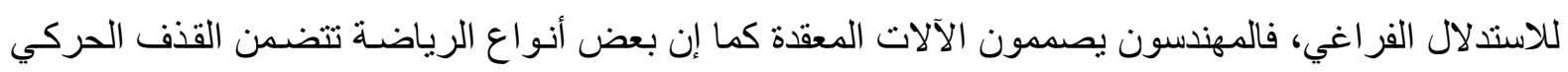
مثـل رياضــة رمسي الـرمح أو القـرص وكـل ذلــك يتطلـب نـوع خـاص مـن الاسـتـلال الفر اغـي الحركي .

(Forbus, $, \cdot 17: \leqslant 1 \wedge$ )

و أنــارت البحوث المعاصـرة في مجـال القدرات الفراغيـة إلى أن المعرفة الفر اغيـة تمتــاز بأنها مرنـة

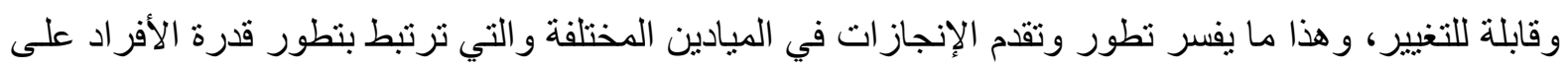
الاستدلال بالتشكيلات الفراغية، وأنشارت دراسـات إلى إن الأطفال و المر اهقين الذين يمتلكون استدلالاً فر اغياً Newcombe ). عالياً سيكونون مبدعين في المستويات التعليمة كافة وفي المهمات التي تتطلب مهار ات فر اغية ولية

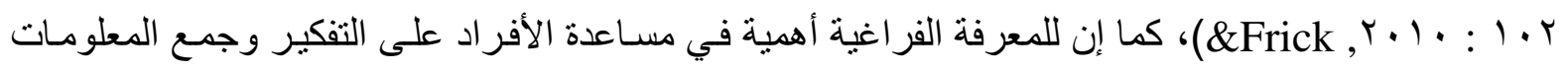

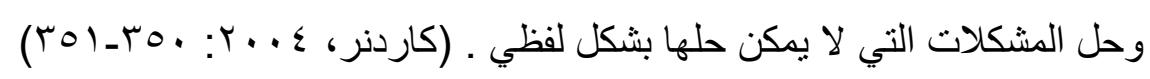
وكمـا يعد الاسـتـلال الفراغـي مـن العو امـل الأساسية لـلإدر الك و المعرفـة، إذ يعد مـن العوامـل المهـــة المتضمنة في الحدس الهندسي، و الذي يقع ضمن اغلب المهمات المعرفية العامة، إذ نتمكن من خلاله من مقارنـة

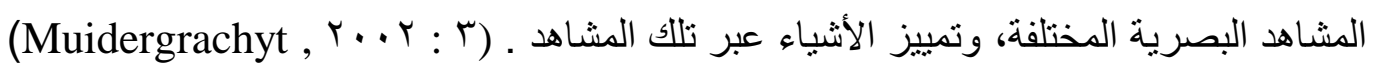
وإن الارتقـاء و التطـور في أي دولـة مـن الـدول يعتمــ على طبيعـة مخرجاتهـا التعليميـة، إذ إن هـذه

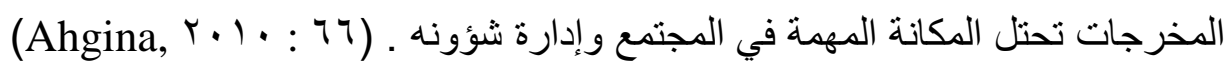

وتعد المرحلة الإعداديـة ذات أهميـة كبيرة فهي تهدف إلى تتميـة شخصية الطالب في جميع جوانبهـا

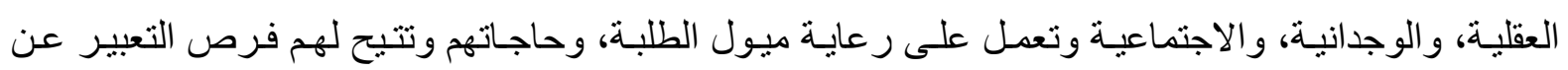

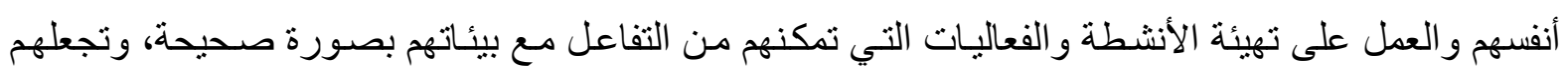


قادرين على التوافق النفسي ـ (الطعاني، 991 ( 199 ( ) )، كما إنها تقدم الخبرات العلمية للطلاب التي تزودهم

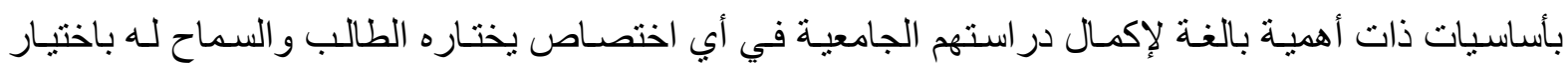

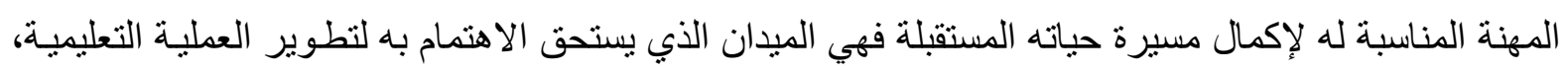
والعمل على إجر اء العديد من البحوث التطبيقية التي تعمل، وتهتم بتكامل شخصية الطالب معرفياً ومهاريـاً ووجدانياً .ويمكن أن تتجلى أهمية الدر اسة بصورة عامة في جانبين أحدهما نظري، والآخر تطبيقي .

\section{أولاً : الجسانب النظري The Theoretical Side} • إن در اسة الاستدلال تعد من الدراسات المهمة التي نالت مكانـة منميزة في البحوث و الدر اسـات، ويعد

موضوع الاستدلال الفراغي من الموضوعات النادرة في البحوث و الدراسات العر اقية حسب اطلاع الباحث .

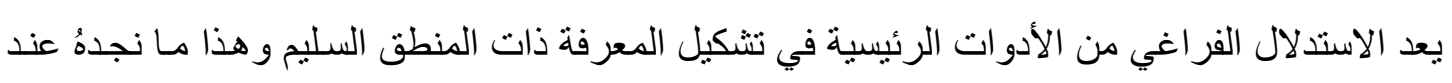

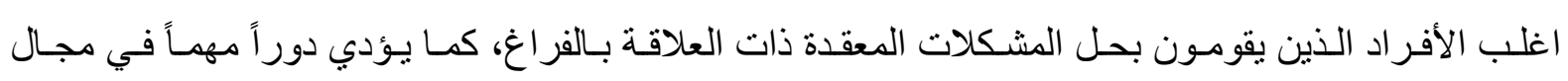

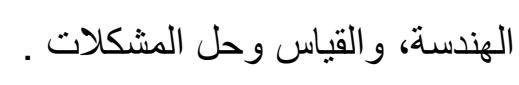

وتزداد أهمية الدراسة لأنها تتاولت دراسة طلبة المرحلة الإعدادية التي تعد من أهم المر احل في بنية التعليم العام وحلقة الوصل بين التعليم الأساس و التعليم العالي .

The Practical Side ثانياً : الجانب التطبيقي تزويـ الميدان التربـوي باختبـار ات تعدل على تنـخيص الاستـلال الفر اغي، إذ وفر الباحث اختبـار الاستدلال الفر اغي .

إمكانية نوظيف نتائج هذه الدراسـة في التعرف على مدى امتلاك طلبـة المرحلة الإعداديـة للاستدلال الفر اغي . • إمكانيـة إفـادة وزارة التربيـة والتعليم العر اقيـة من النتائج المترتبـة على هذه الدر اسـة في بنـاء المنـاهج الدر اسية أو صياغة الأهداف التربوية الموضو عية والخاصة بمرحلة التعليم الإعدادي . Objective of the Research : أهداف البسحث يهدف البحث الحالي إلى تعرف : rـ الاستدلال الفر اغي لدى طلبة الصف الخامس الإعدادي . عـ دلالة الفروق في الاستدلال الفراغي تبعاً لمتغيري الجنس (ذكور، إناث)، و التخصص (علمي، أدبي) . Limits of the Research : حدود البحث أولاًا : الحلدود الموضومية بالاستدلال الفر اغي لدى طلبة المرحلة الإعدادية .

\section{ثانياً : الحسدود الزمهنية}

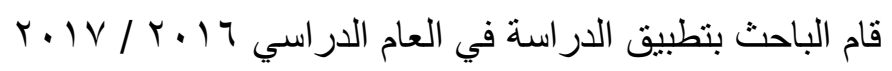


ثالثاً : المحدود المكانية

قام الباحث بنطبيق الدراسة في مدينة الكوت مركز محافظة واسط .

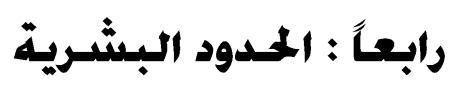

تحددت هذه الدراسة بطلبة الصف الخامس الإعدادي .

Define Terminology : خديد المصطلحسات قام الباحث بتحديد المصطلحات الواردة في البحث هي:

(

ييرن (Byrne,1919) هو القدرة على وضع الخطط وتحديد الفعاليات وتصور الأثشياء من خـلال

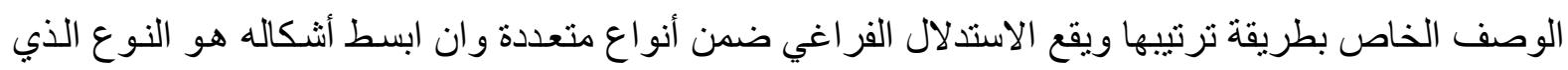

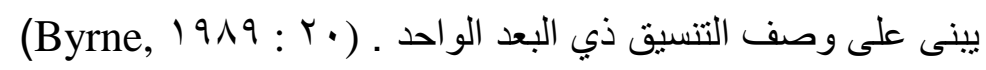
كليمنس وباتيستا (Clements \& Battista , 199 ) هو مجمو عة من العمليات الذهنية التي يتم عن

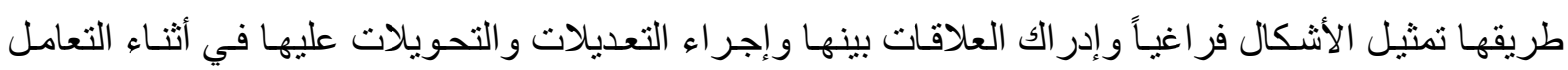
(Clements \& Battista, 199r:

كارولس (Carrols, r. . ب. بأنه القدرة على حل المشكلات الفر اغية من خلال فهم ماهية الأثكال

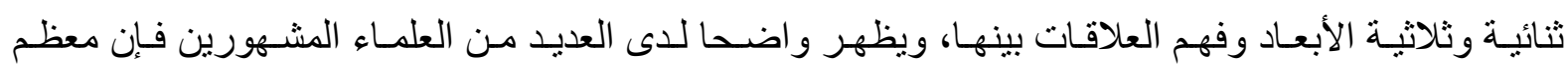

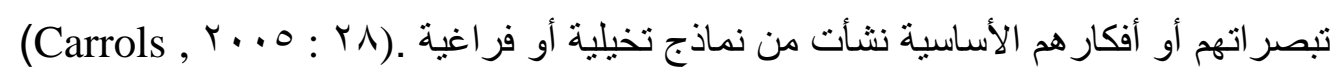

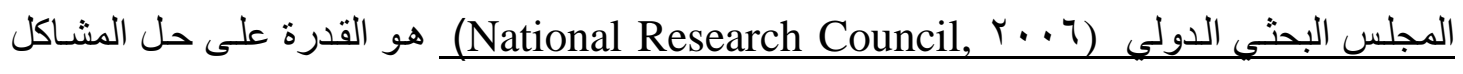
الفر اغية من خلال إدارة وتحويل وتحليل البيانات وخاصة مجموعة البيانات المعقدة والكبيرة، من اجل إيصـال

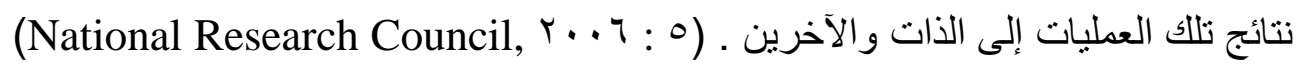
التعربف النظري : اعتمد الباحث تعريف كليمنس وباتيستا (Clements \& Battista , 199) كتعريف نظري للاستدلال الفر اغي في هذا البحث . التعربف الإجرائي : هو الدرجة الكلية التي يحصل عليها الفرد من خلال أجابته على فقرات اختبار الاستدلال الفراغي.

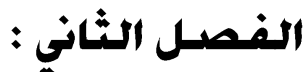

\section{1 - التطور التاريخي لمفهوم الاستدلال الفراغي}

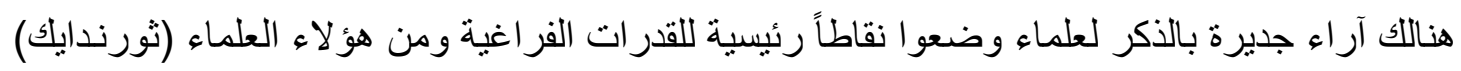

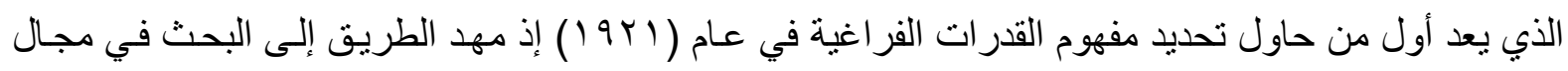


الاستدلال الفر اغي وذلك من خلال تعريفه (للذكاء الميكانيكي) على إنه القدرة على تصور العلاقات بين الأشياء

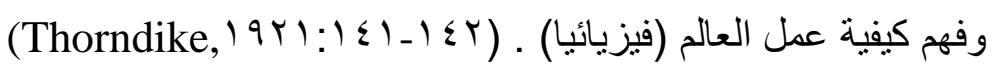

وفي عام (1^rو () درس ثرستون القدرات العقلية الأولية وعرّف عامل الفراغ على (إنه القدرة على

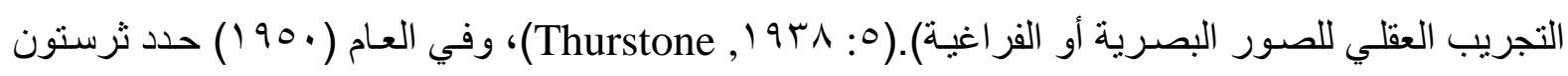

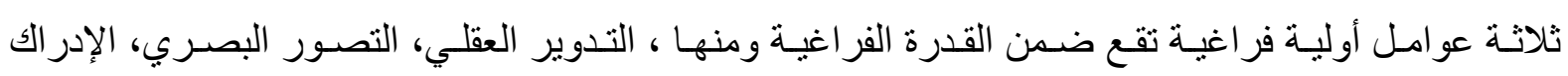

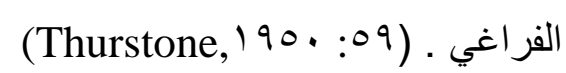

وتعد أعمال بياجية في عام (9VI | ) خير مثنال على متابعة التطور الحاصل في الاستدلال الفراغي لـدى الأطفـال، إذ طـور بياجيـة عدة اختبـار ات خاصـة بـذلك المجـال مـاز الت تسـتعمل في الوقت الحسالي .

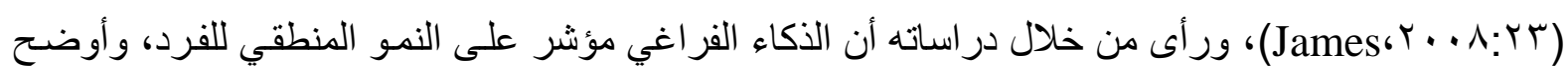

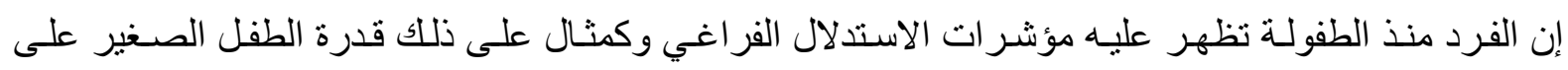
تنـكيل صـور عقليـة متخيلـة، وقدرة المراهـق على تكوين علاقـات فر اغيـة مـن خـلال الوصـف المنطقي .

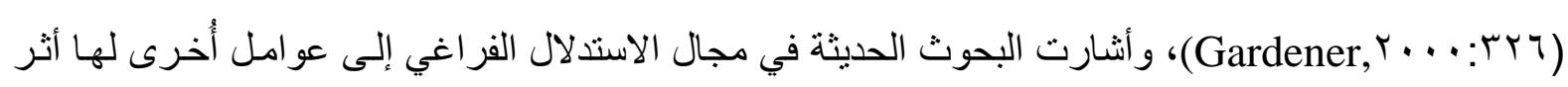

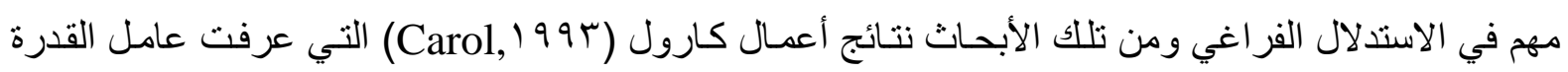
الفر اغية (القدرة على تنكيل التمثيلات العقلية الداخلية للأنماط البصرية واستعمال منثل تلك التمثيلات في حل المشكلات الفر اغية)، أما العامل الآخر فهو(القدرة الفر اغية الديناميكية) و التي تم اختيار ها من قبل كل من هانت ودي أُولفيرا (Hunt) العناصر المتحركة والحركة النسبية كل هذه الأبحاث حاولت الإجابـة عن كيفية تطور الاستدلال الفراغي . $($ James, $, \cdots \wedge:$ ro) وقد أظهر روجر شيبارد أحد رواد الاستدلال الفراغي والتدوير العقلي إن الوقت الذي يحتاجه الفرد للحكم على شكلين ملتويين يعتمد على عدد الدرجات التي يفترض بـالفرد أن يحرك فيها أحد الثكلين حتى

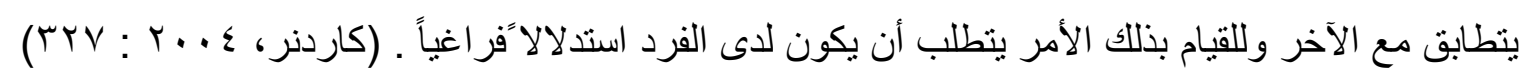

\section{r - مفهوم الاستيدلال الففراغي}

لقد حظيت القدرات الفر اغية بشكل عام والاستدلال الفر اغي بشكل خاص على اهنمـام العديد من علمـاء النفس والرياضيين التربويين على الصعيدين العالمي والعربي من خلال دراسة تطور هذه القدرة لدى المتعلمين مع تقدمه في العمر أو المستوى وتبدو هذه القدرة في كل نشاط عقلي يتميز بالتصور البصري لحركة الأشكال

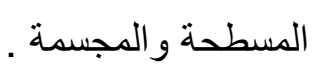

و الاستدلال الفراغي هو عبارة عن قدرة تتطور بشكل طبيعي وتستمر بـالنمو مـع استمرار العمر ويعد قدرة أساسية مـن قدرات الاستـدلال ويسر جنبـاً إلى جنب مـع الاستـلال اللفظي والمنطقي و العددي، و الفرد

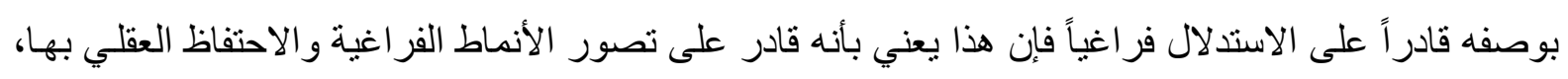


إذ يسهم الاستدلال الفر اغي في جعل تعامل الفرد مع عالمـه أسـهل وبدون ذلك يكون الفرد غير قادر على فهم

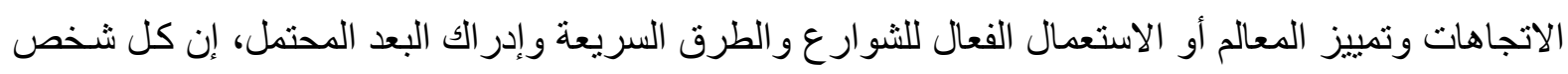

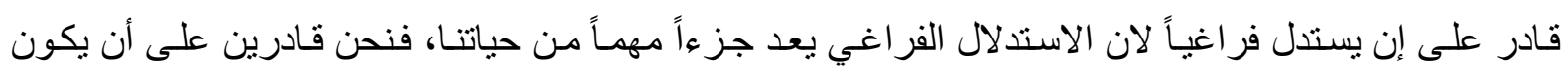

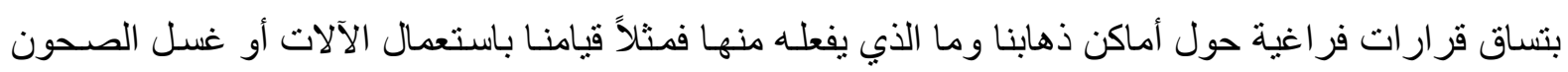
أو قيامنا بالتخطيط لكيفية وضع وترتيب

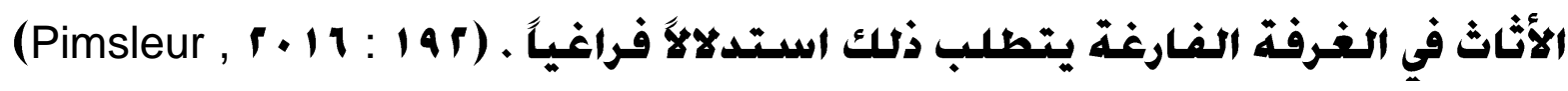

إن الاستـلال الفر اغي ينشـأ ويعزز من خـلال التفاعل المستمر بين استحضـار الأفكار والحركات في في

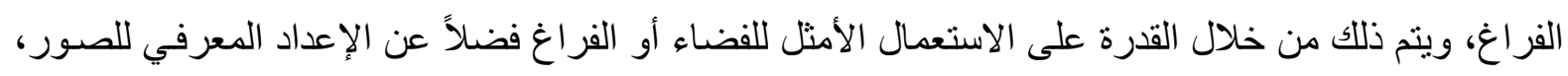
ومن خلال تسليط الضوء على العلاقة بين الإنسـان و الفضـاء أو الفراغ، إن الفضـاء ليس فقط عبارة عن سياق للمدى البشري بل يعد بمثابة منظم للمعرفة، إذ إن التفاعلات بين الإنسـان والفضـاء كعملية مستمرة لا تتضمن الإنسان على المستوى المادي فقط كالاحتفاظ الفيزيائي أو استعمال المصادر أو التكيف البيئي، لكنها تسمح للفرد

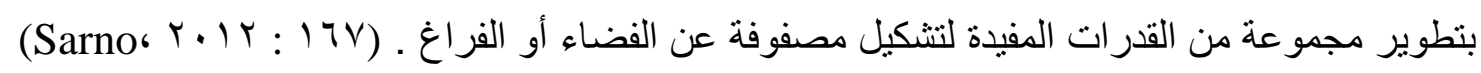
ويعرف الاستدلال الفر اغي على انـه الاستدلال حول الكيانات المحدودة في الفراغ والتي تملك أبنية فر اغية والتساؤل هنا كيف يمكننا تمثيل تلك الكيانات المحدودة فر اغياً والأسباب المتعلقة بها ولتوضيح ذلك على الكى سبيل المثال عندما نجلس على المنضدة ونضع الملعقة إذن ما الاحتمالات الفر اغية لهذه الفقرة الجديدة بعلاقاتها بالأخرى هناللك جو انب أساسية ابعد للإدر الك فنحن نمتلك القدرة على مقارنـة المشـاهد البصرية المختلفة وتمبيز

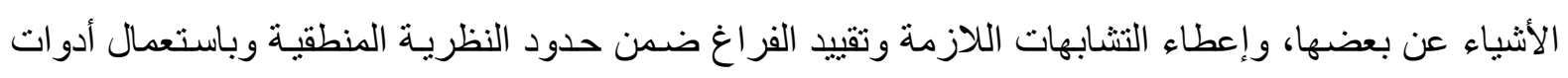

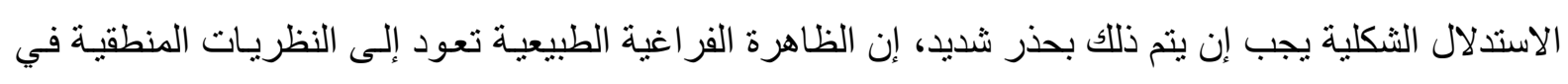
الفراغ ويشير بعضهم إلى إن الفراغ في طبيعته عبارة عن رسم بياني أو خط بياني محدد ومقيد بمجموعة من الأن

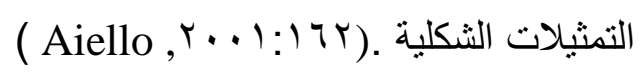

وينطوي الاستدلال الفر اغي على موقع وحركة الأشياء والأشخاص في الفراغ إما عقلياً أو فيزيائياً فهو

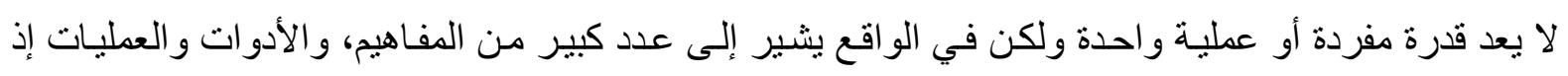

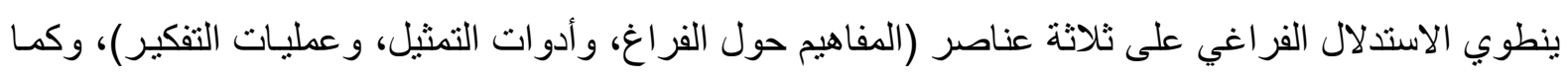

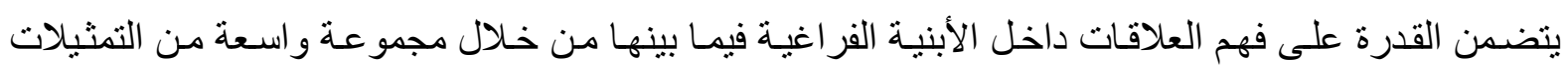
المحتملة (من الرسومات إلى نماذج الكمبيوتر) كما ينطوي على وسـائل التو اصل فيما بينها فعندما يقوم الطفل مثلا بتدوير الموشور الثثلاثي الأبعاد لتنبيته في السقف الذي يقوم ببنائه في وسط المكعبات فهو يقوم بعرض استدلاله الفر اغس، و عندما يستعمل المتعلم الرسم البياني للمثلث لإثبـات مسـاحة المثلث فإنـه يظهر استـلاله الفر اغي أيضاً، لذا فإن الاستدلال الفر اغي يشكل قدرتنا على استقصاء، وحل المشكلات وخصوصا المعقدة غير الروتينية، وتربط بعض المناهج بين التصسور الفر اغي والهندسة لكون كل منهما يرتبط بـالآخر بشكل متأصل فالهندسة مثلا تترجم إلى إنها (قياس الأرض) فهي تعني بشكل مباشر بقياس الأشياء وحركتها في الفراغ كما إن 
الهندسة تعد أساساً للرياضيات كما تعرفها اليوم وقد وضعت لتطوير وتوضيح الظو اهر وحل المشكلات التي

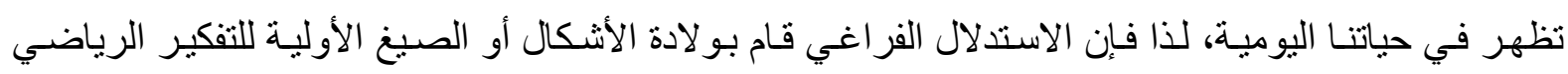

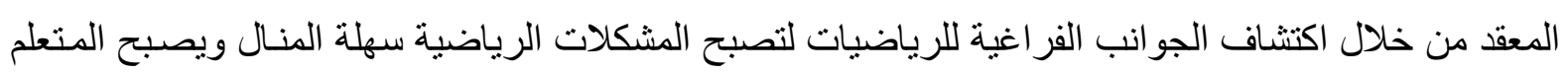
أكثر انغماساً فيها فمثلا العالم عالم الفيزياء المشهور(البرت انشتاين) توصل إلى نظرية النسبية من خلال تصور نفسه وهو يقود حزمة من الضوء (Clements\&Sarama,

و الاستدلال الفراغي مرن ويمكن أن يتحسن من خلال التعلم والخبرة، وإن اغلب الاعتقاد كان يرى بأن

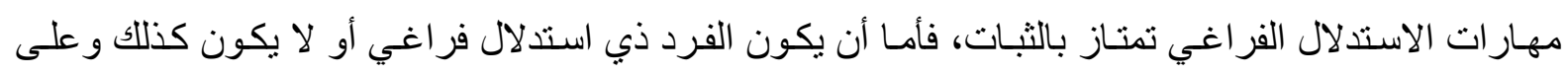
العكس من ذلك فإن الاستدلال الفراغي يتككن من عدت مهار ات ولهذا السبب فإنه يمكن تفعيلة أو تنشيطه في لهي بعض جو انبه من مثل مهارات التنقل عبر الفراغ وقد يكون قوية لدى الفرد بينما مهار ات أخرى مثنل مهارات

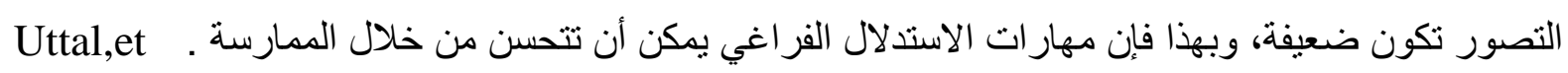

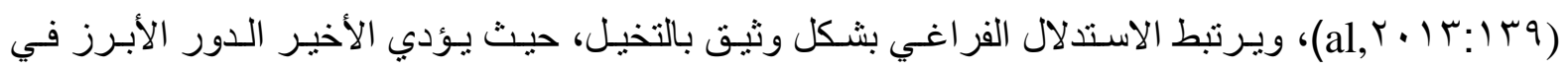

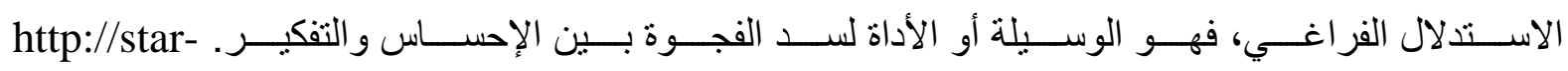

(manar.blogspot.com)

$$
\text { r- ا- وظائف الاستدلال الفراغي }
$$

r- وصف العلاقات الفر اغية باستعمال النماذج الهندية في حل المشكلات .

$$
\text { ( } 1997 \text { : عابد، } 197
$$

r- فاعليتها في تعلم الرياضيات، وإضافة معنى للخبرة الرياضية، فضلاً عن أهميته سو اء للموضو عات

العددية (Numerical) أو الهندسية (Geometric) .

(Wheatley, 199.: 11)

عـ تيسر للمتعمين تكوين حلول تخيلية للمشكلات الرياضية، وبدونها يصبح تعاملهم مـع هذه الموضو عات

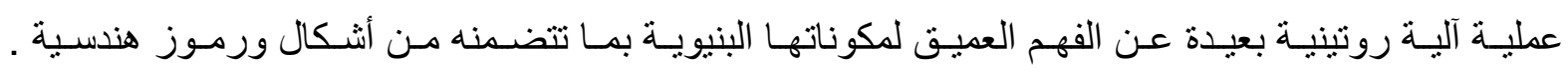
(Wheatley \& Reynolds, $1999:$ rV $\varepsilon_{-} r \vee 0$ ) هـ ـللاستدلال الفر اغي أهمية كبيرة في التنبؤ بالنجاح المهني وفي توجيه الأفر اد للأعمال المناسبة لهم آ- يسـاعد في اختيار الأفراد الذين يصلحون لكل مهنـة من المهن وفي الوظـائف والتخصصـات المتنوعـة . ( (زيدان ونبيل، • 199) 
Vـ الاسـتـلال الفر اغي مهم في الوظـائف التصـميمية و الفنيـة المرتبطـة باستعمال الرسومات و المخططسات،

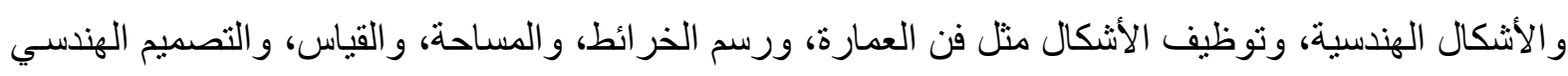
و المواضيع الرياضية .

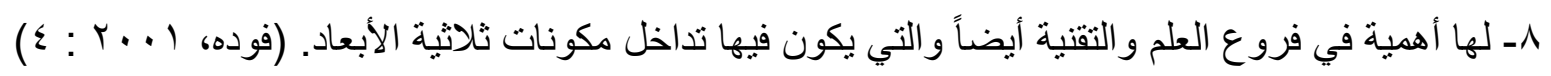
9ـ كمـا إن الاستـلال الفر اغي يؤدي إلى المسـاعد في تعلم كثير من المهار ات المعرفيـة ولاسيما المرتبطـة بالرياضيات و الهندسة و العلوم و الكيمياء و الفيزياء و الجغر افية . لـولئ.

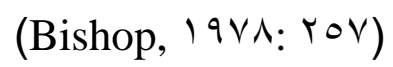

• ا - يؤدي الاستدلال الفر اغي دوراً كبير اً مهماً في الحياة اليوميـة، إذ تدخل قدر اتهه في العديد من التفاعلات

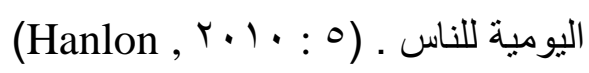

11 - يعد الاستـلال الفر اغي ضـروري للتفكير العلمي لأنـه يستعمل في تمثنيل ومعالجـة المعلومـات في أثنـاء

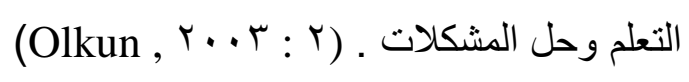

ب ا - يسـاهم في تطوير المجـال التعليمسي كتعلم اللغـة و الرياضيات، إذ يحتـاج المتعلمون معرفـة اللبنـات التـي

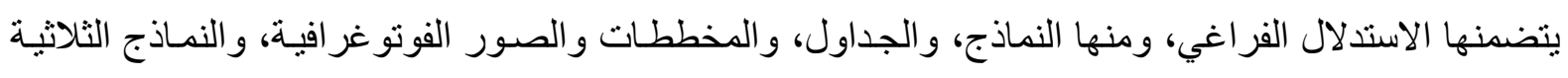

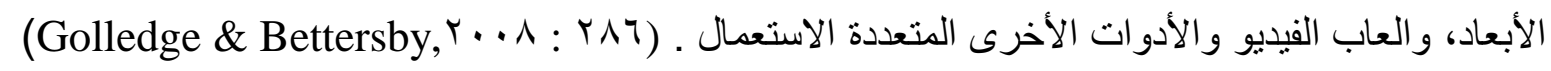
ع- الخصائص المعرفية للطالب المتصف بالاستدلال الفر اغي أو لاً : يتحمس للتعقيد ويهتم بحل الألغاز الصعبة .

ثانياً: يكون مبدعاً في الهندسة والفيزياء ويستمتع باستعمال الحاسوب ويتمكن من تحديد موقع أغلب الأشياء . ثالثاً: يكون لديه ذاكرة بصرية قوية، ويكون تفكيره منظم . رابعاً: يمتلك قدرة على الملاحظة والاستدلال و التحليل الرياضي .

خامساً: يمتلك فهماً قر ائياً عالياً، ويقر أ الخر ائط و الرسومات البيانية والجداول بسهولة ويستجيب إلى المخططات و الرسومات اللونية .

سادساً: يفكر من خلال الصور المتخيلة، ويستعمل تلك الصور و التمثيلات البصرية في حل المشكلات . سابعاً: يمتلكون قدر ات مثيرة على قر اعة الآخرين، مثل (القدرة على قر اءة لغـة الجسد، والتعبير ات الوجهيـة) . (Silverman, 1997: ^ґ^)

ثامناً: إن الطالب ذي الاستدلال الفر اغي العالٍ يستعمل استر اتيجيات تخيلية أكثر نجاحاً من اقر أنه ذوي القدرات

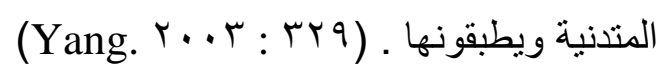


تاسعاً: لدية القدرة على تخيل دوران الأشكال حول المحور، وكذلك الكيفية التي يكون عليها الثكل إذا نظرة إليه

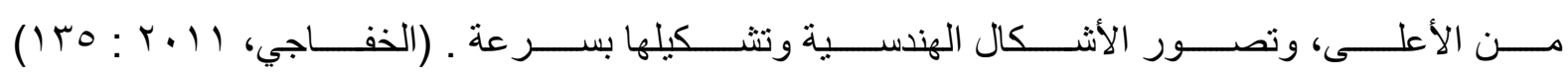
عاثر اً: لديه القدرة على قطع الصورة و إعادة تجميعها بنفس الصورة و إنشاء صور اً بصرية لما يصفه الآخرون

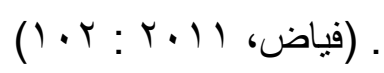

0ـ المتغيرات التي تؤثر في القدرات الفر اغية (الاستدلال الفراغي) تعزى الفروق في هذه القدر ات الفراغية، ومنها الاستدلال الفراغي إلى مجموعة من المتغيرات وهي : اـ التطور المعرفي : يرتبط هذا العامل بمر احل التطور المعرفي كما حددها بياجية، وعليه تفسر الفروق في القدرة الفر اغية إلى التفاوت في هذه المر احل . ل ז- الخبرة : فقد تبين أن القدرة الفراغية لدى الأفر اد تتأثر بالخبرات المكانية وهذا الأثر قد يمتد إلى مجمل هذه القدرة أو إلى بعض جو انبها ويتوقف ذلك على طبيـعة هـذه الخبـرات و أنماطهـا، إذ بـينت دراســة مينـرو

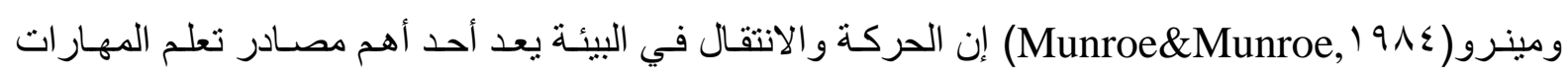

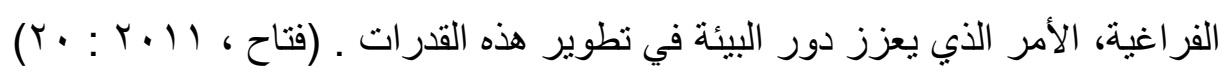
r- الجنس : بينت نتائج معظم الدراسات وجود علاقة بين القدرات الفر اغية والجنس، وقد تعود هذه الفروق إلى طبيعة الاستر اتيجيات المعرفية المتبعة لاى كلا الجنسين، و على الرغم من ذلك فإن هذه العلاقة لم تحسم بعد في

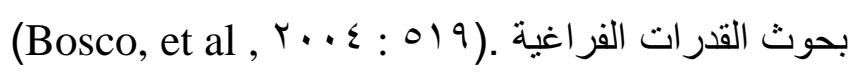
عـ المو هبـة (الذكاء العـام) : تـرتبط المو هبـة بالقدرة الفر اغيـة، فالمو هبـة تحـدد استر اتيجيات المعالجـة الذهنيـة

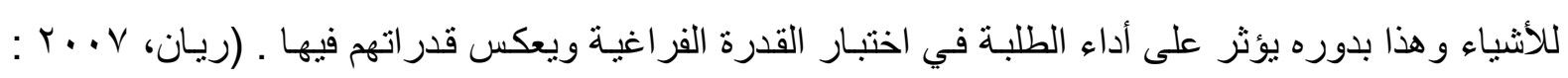

ـ ـ العوامل البيولوجية : تؤدي العوامل البيولوجية إلى ظهور هذا الفرق ومن هذه العوامل الهرمونـات، إذ تؤكد

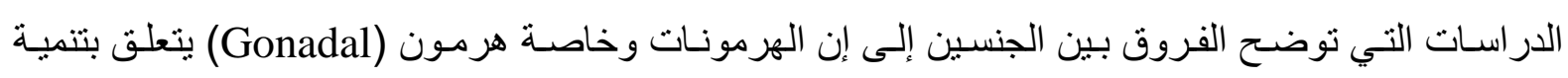
المهار ات الفر اغية، إذ يؤثر في ذلك، وكذلك سيادة الجانب الأيسر من الدماغ في التفكير للدى الإناث، وسيادة

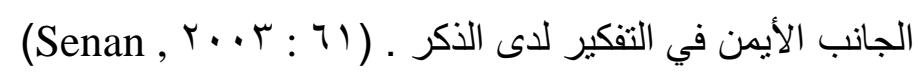

7 ـ العو امل الاجتماعية : إن التنشئة والتعليم لها أثررٌ في ذلك فالعاب الأطفال الذكور اغلبها ذكوريـة تتعلق بمهام يدوية تتمي الخيال، مثل أدو ات أعمال البناء، وقطع التركيب و التي تعمل على تتمية خيال الطفل الذكر من

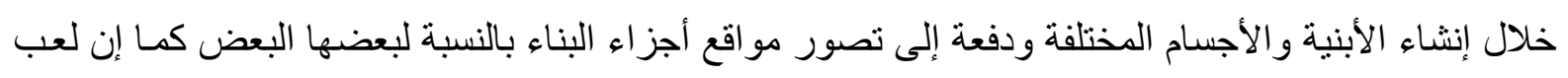

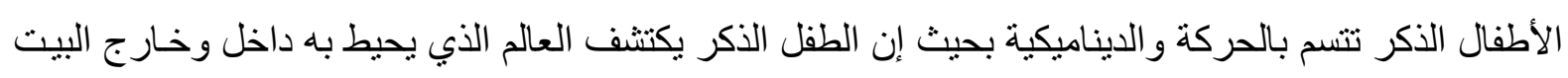

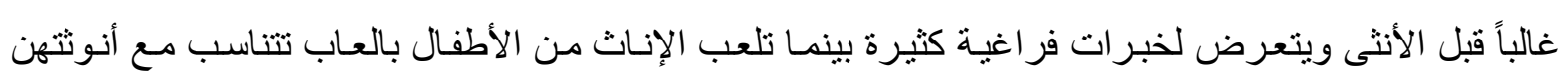
كالعاب الدمى وكما إن الأنثى يجب من منظور اجتماعي أن تتسم بالهدوء وان لا تتحرك كثير اً مثنل الذكور ممـا لإنا 
يؤدي في النهاية إلى حرمانها من الخبرات الحياتية الفر اغيـة التي يتعرض لها الطفل الذكر ومن ثم لا تحصل

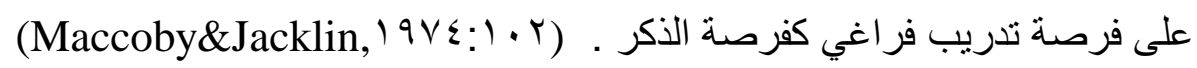

\section{1- قدرات الاسـتدلال السفراغي}

يمكن تقسيم قدرات الاستدلال الفر اغي على القدرات الفرعية الآتية :

ا - قدرة إعادة تجميع أجز اء الثكل وتنظيمـه من خـلال معالجـة الأشياء دورانـاً وتغيير الاتجـاه و إدر الك النواتج

(Newton, r. . $q: r r)$.

r-ـ قدرة إدر اك العلاقات الفر اغية بين الأجز اء المكونة للثكل الناتجة من الدوران في الفراغ وتمبيز الأشكال

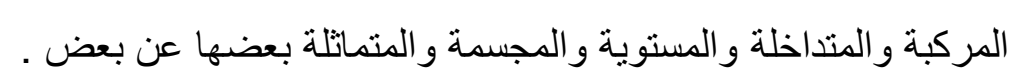

بـ قدرة فصل الأشكال المركبة عن خلفيتها، وتحليل الأشكال المعقدة إلى الأجز اء المكونة لها .

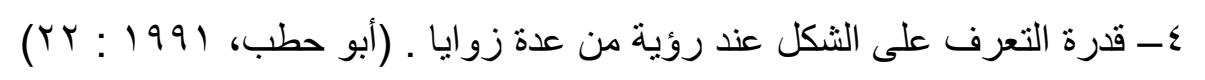

0ـ قدرة إدر الك الأوضاع المختلفة للأشكال و إجراء المقارنـة والمطابقة و المنـاظرة لإيجـاد التشـابه والاختلاف

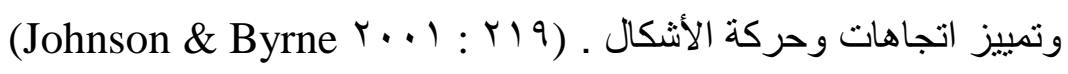

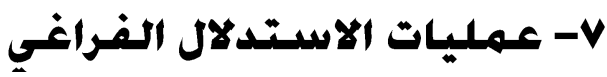

توصل بعض الباحثين إلى القول أن الاستدلال الفر اغي نفسه ليس شيئًا واحداً أو عملية واحدة بـل مجموعـة من العمليات نذكر منها : بوصن

\section{أ - ملاعمة العين والحركة (eye - motor coordination)}

هي القدرة على ملاعمة حاسة البصر مع حركة الجسم أو حركة اليد، مثلاً عندما نطلب من الأطفال أن

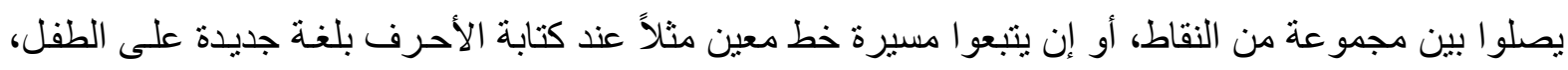

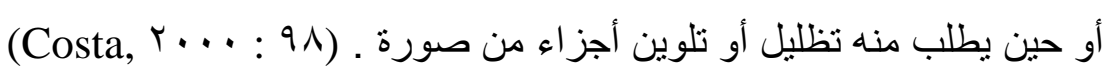

\section{(figure - ground perception) ب - إدراك شـكل- خلفية}

نحصل على أكثر من (ع ) مثلثات هي المثلثات المنفصلة الظاهرة للعيان كذلك تتضمن هذه المهارة تمييز شكل بين مجموعة من الأشكال المتداخلة، إكمال شكل حسب نموذج معطى و نركيب صورة من أجز ائها

\section{ج - ثبات الشثكل إدراكياًا (perceptual constancy)}

و هي القدرة على الإدر اك إن الثكل لا يغير صفاته أو ماهيته حتى لو تغير موضعه أو تغيرت

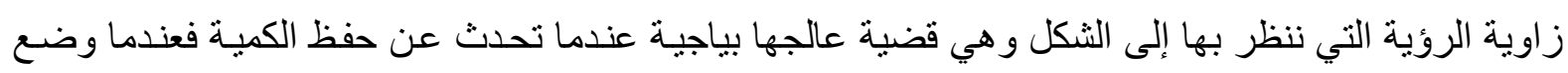
بياجية الكمية نفسها من الحبر السائل في أنبوبين احدهما سميك والأخر دقيق، ارتفع المـاء في الأنبوب الدقيق أكثر مما ارتفع في السميك بحيث ظن الأطفال إن كمية المياه في الأنبوب الدقيق هي أكبر، وفي الهندسـة يرى الأطفال المربع في وضعه الطبيعي عندما يكون موضو عاً أفقياً، أمسا إذا كان و اققاً على واحد من رؤوسئه فقد 
يرونه شكلاً معيناً، وملعب كرة القدم وهو مستطيل الثكل ويبدو لنا عندما نراه من الخارج من جهة المرمى شبه منحرف وقد نر اه من زاوية أخرى متو ازي أضلاع و عندما نر غب برسم مكعب فإنتا نبدأ برسم منوازي أضـلاع كقاعدة لهذا المكعب بينما القاعدة الحقيقية هي مربع، وفي الهرم تبدو الأضلاع من الجهة البعيدة عنا في الرسم

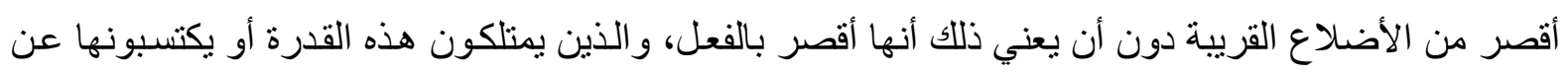
طريق المر ان يسهل عليهح تخيل شكل جسم بعد إن ننقله أو نديره أو نجري عليه بعض التغيير على سبيل المثنال فرش مجسم مثل المكعب أو الهرم وهي الصورة الهندية المستوية التي نحصل عليها عندما نفكلك سطح الهرم

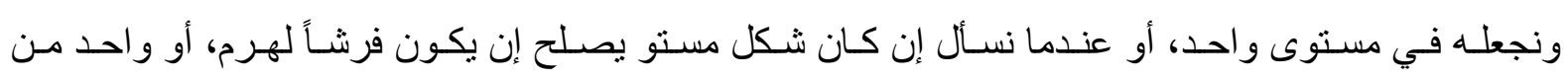
المجسمات، مثال آخر عندما نطوي ورقة مرة واحدة أو أكثر ثم نثقبها في موضع واحد ونعيد فتحها فمـا هو الثكل المتكون لها، هذه القدرة تتبع صيرورة الأشياء التي تسير في سلسلة من التغييرات المحسوبة، وكل هذه الأمسور تتطلب قدرة على الخيـال أو التخيـل يملكها بعض النساس و لا يملكها غيرهم وتعليم الهندسـة بالثـكل الصحيح باستعمال الفعاليات والأدوات المحسوسة، إنما ينمي هذه القدرة على التخيل في أوضاع مشابهة أو حتى لـى

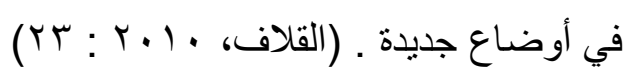

\section{د - إدراك العـلاقات في الفراغ (perception of spatial relationships)}

وتعني القدرة على فهم الترتيب أو التشكيل الفراغي للأشياء أو الأجزاء في تلك الأشياء وعلاقتها

بعضها مع بعض وكمثال على ذلك عندما يطلب من الطالب أن يكمل نموذجاً مـا كمـا في سلسلة الأشكال في

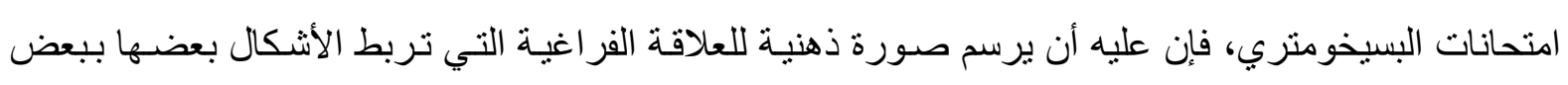

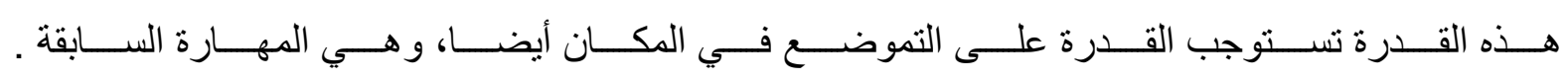

(Aszalos\&Bako, $, \ldots \varepsilon:$ r $)$

\section{هـ - القدرة على التمييز البصري (visual discrimination)}

وهي القدرة على التمييز البصري للأشياء كما ير اهـا المر ء من خـلال المقارنـة بين الأشكال عقلياً و إيجاد أوجه التشابه والاختلاف بينها، وخصوصا عندما تكون هذه الأشياء متشـابهة وبعكس المهار ات السـابقة فإن هذه المهارة غير متعلقة بصورة مباثـرة بالمكان أو بالعلاقات الفر اغيـة وامتحانـات البسيخومنري طافحة

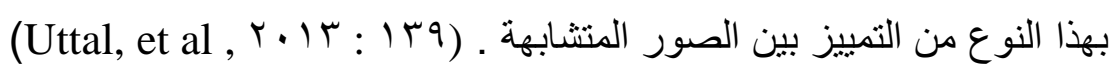

و- إدراك الموضـع في الفـراغ (Perception position in space)

هي قدرة المرء على إدر الك مواضع الأشياء وتحديد موقعه بالنسبة لـه، فلو سـألت طفلاً أن يشير للك

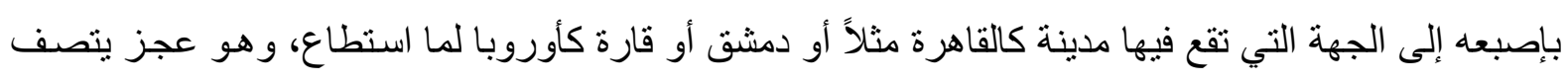
بـه البالغون أيضاً لعدم نمو حس العلاقة الوضعية بينهم وبين الأماكن أو بين الأماكن بالنسبة لهم وهؤلاء يعيشون

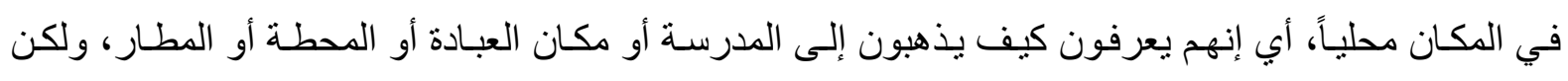

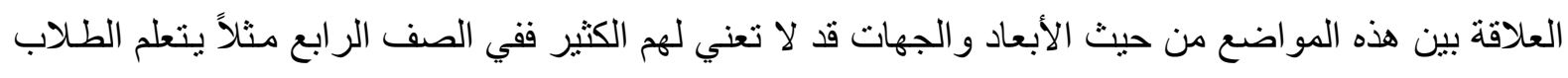
أنهم إذا أداروا وجو ههم ناحية الثمال فإن الثرق سيكون على يمينهم و الغرب على يسار هم ولكن لو سألو هم أين 
سـقع الثـرق والغـرب لـو أداروا وجـوههم ناحيـة الجنـوب، لــا استطاعوا الإجابـة ولكن طلابـاً أكبر سـناً قـد يستطيعون الإجابة عن مثل هذا السؤال، وقد يجد بعض الطلاب صعوبة في التعامل الفراغي حتى في الأشكال القريبة منهم، مثنلاً التمييز بين الحروف (d,b,p) في اللغـة الانجليزيـة، ممـا يسبب إعاقة في القر اعة والكتابـة عندهم ويبدو أن الدسلكسيا (Dyslexia) وهي صعوبة أو عسر في القراءة والكتابة وفي الرياضيات مرتبطة أو متأتية من عدم القدرة على التعامل مع المكان أو الحيز المحلي فتكون مصاحبة لعدم التمبيز بين اليمين واليسـار أو التمييز بين العددين ج و ب في الأرقام الهنديـة، أو ج و 9 في الأرقام العربيـة وفي الحسـاب قد يجد الطفل

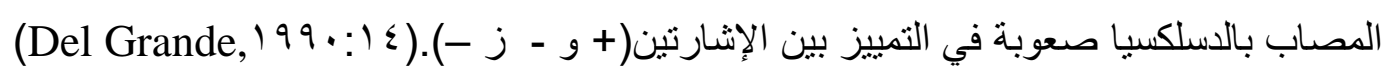

\section{(visual memory) س- الذاكرة البصـرية}

هي القدرة على تذكر صور أغراض رأو ها والاحتفاظ بهذه الصور لفترة طويلة وتشمل هذه الذاكرة

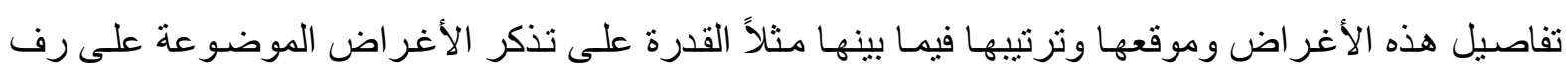
وترتيبها بعد أن تكون غابت عن العين، وفي المقابل يصـعب على بعض النساس تذكر وجوه نـاس قابلو هم و عرفو هم ويوصف النـاس الذين يملكون مثنل هذه القدرة على التذكر بإنـاس أصـحاب ذاكرة فوتوغر افيـة،

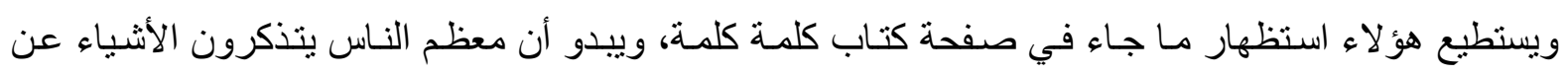
طريق ربطها بصور حية، وهم يحتفظون بهذه الصور زمناً طويلاً ولذلك يملك أصحاب الذاكرة البصرية ذاكرة

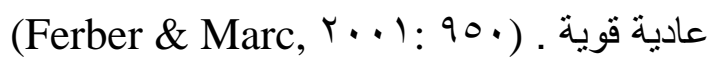

\section{^- مهام الاستدلال الفراغي}

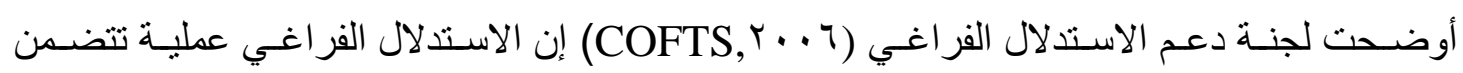

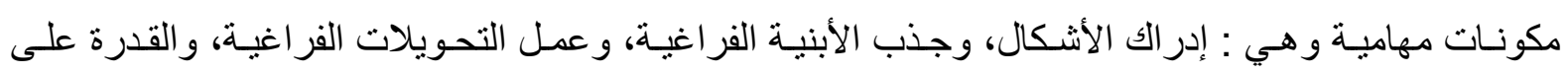
استعادة أجز اء مـن الخبـرة البصـرية في غيـاب المثير الحسـي المباثـر، ومـن ثـم وضـع الأحكـام الاســدلالية الفر اغية، ولذلك فهي تثير بوضوح إلى إن الاستدلال الفراغي يستعمل التمثيلات ليسـاعدنا في التذكر والفهم

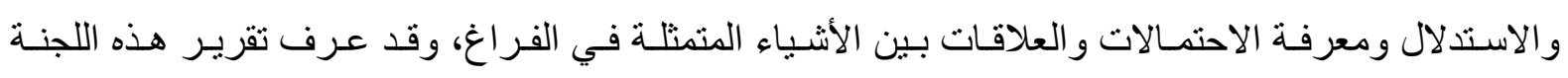
الاستدلال الفر اغي على انه القدرة على فهم العلاقات الفر اغية ومعرفة كيفية تمثيل الفراغ الجغر افي و انسه القدرة

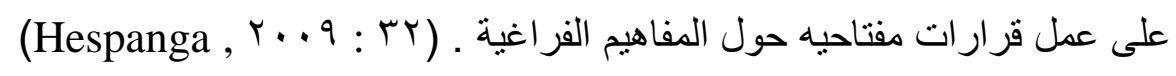

\section{4- الاستدلال الفراغي والذاكرة العاملة البصـرية الفراغية}

إن العديـد مـن مهمـات الاســدلال الفر اغـي تعتمـد على الذاكرة (الصـورية الفراغيـة) إذ تشـير الذاكرة البصـرية الفر اغيـة إلى الاحتفاظ المؤقت (الذاكرة قصيرة المدى) و الاحتفاظ بالمعلومـات البصرية و الفر اغيـة،

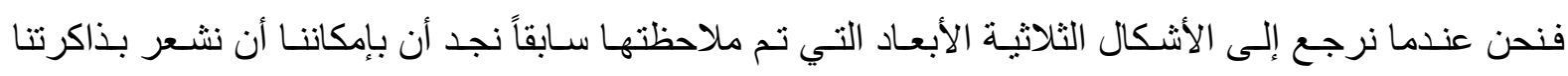
الصورية الفر اغية من خلال الصور في عقولنا إنها تم الاحتفاظ بها فر اغياً أو ترجمتها وتحويلها بطرق مختلفة برتة من خلال التدوير العقلي وتثبر اغلب البحوث إلى إن الاستدلال الفراغي يلعب دوراً استثنائيا في تعلم العلوم إذ يحتاج المتعلمين إلى تذكر كل المعلومات اللفظية البصرية الفراغية إذ يحتاج المتعلم إلى كل من تلك المعلومـات 
في اغلب المهمات الأكاديمية، ويستطيع المعلم من خلال قيامه بهذا النشـاط من تنمية الذاكرة البصرية الفر اغيـة حيث يطلب المعلم من طلبة أن يركزوا انتباههم على الثكل و البنيـة والعلاقات الهندسية، وذلك لإعـادة بنـاء الرسومات الخطية الهندسية من قبل الذاكرة البصرية الفر اغية من مثل مربع ويتخلله خط وقبل البدء بهذا يجب

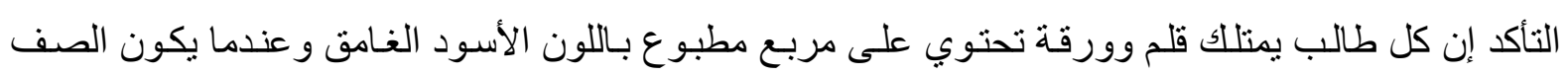
جاهزا يطلب من الطلاب رسماً على اللوحة أو السبورة التصميم الهندسي الذي تم انتقاؤه مع إعطاء الطلبة الوقت للتفحص و التمعن فيه بحذر لمدة خمس ثواني ويجب أن لا يقوم الطلاب في ذلك الوقت بالرسم بل بالتمعن في الثكل المعطى فقط من حيث الثكل و البنية والعلاقات الهندسية، وبعد انتهاء مدة الخمس ثو اني يقوم المعلم بمسـح الثـكل أو إخفائهـ والطلب مـن الطـلاب أن يبذلوا جهدهم على إعـادة بنـاء الصـورة مـن خـلال ذاكرتهم

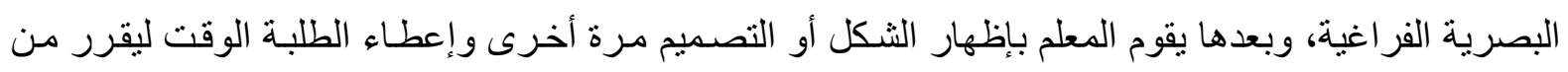
فيما إذا كانت النتيجة المطلوب منهم هي ذاتها، ومن ثم مناقثة الطلبـة من خـلال الأسئلة الآتيـة كيف قام الطلبـة

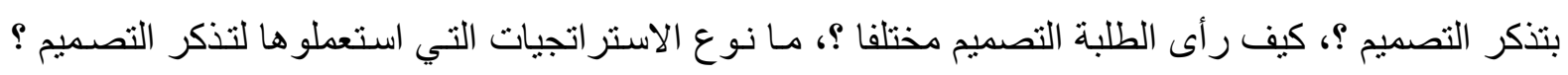
هل هناللك طرق مختلفة يمكن أن يقومون من خلالها برسم التصميم ؟، ومـا الذي ستلاحظه يحدث عندما نقوم بقطع المربع من المنتصف على طول القطع ؟ من خلال المناقثنة الصفية فإن الطلبة سوف يميزون بـأن هنالك طرقاً عديدة للرؤية والتذكر و البناء أو إعادة البناء الفراغ الثناثي الأبعاد،وهذا النشاط يتضمن المهارات الفر اغية بنة

أ - التركيب و إعادة البناء للشكل و الفراغ .

ب - ب الاستدلال التناسبي .

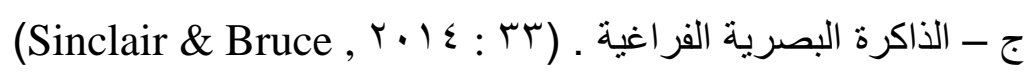

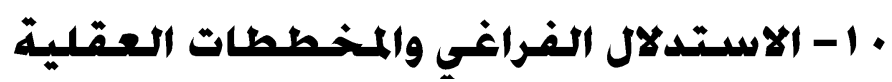

تعد المخططات العقلية وصفاً للخبرة الإدر اكية، وتستعمل لغرض تشكيل الأبنية الفر اغية، وتلك النمـاذج أو الأبنيـة الفر اغيـة تعد ذات فائدة رئيسية لنـا في مجـال حركة أجسـامنا خـلال الفراغ، وقدرتنا على الاحتفاظ بالأشياء في عقولنا وتفاعلاتتـا الإدر اكيـة، كمـا تعد المخططات العقلية عبارة عن نمط عقلي يوفر منهج بنـاء لخبر ات مختلفة كما تستعمل كنماذج لتوفير فهم لخبرات عديدة تساعد في إدر الك التمثيلات و المعاني و الدلالات، Cohen \& Beal , . ويتضمن الاستدلال الفراغي الاستدلال حول الأفعال في الفراغ والذي يتطلب إثارة عقلية

$(r \cdot 7: 1 r)$

\section{ا 1 - قياس الاستدلال الفراغي}

تتطلب اختبار ات القدرات الفر اغية القدرة على التفكير في أشكال هندسية والعلاقات بينها، وان كثير من

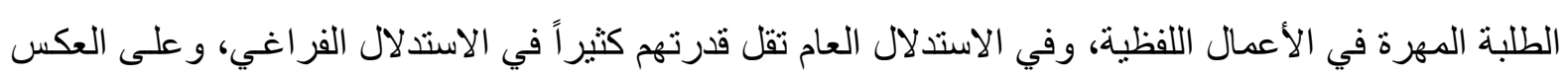
من ذلك فإن قسماً من الطلبة يظهرون استعداداً أكثر تفوقاً في هذا الجانب، وهذه القدرة ينبغي توافر هـا للنجاح 
في در اسة الهندسة كما إنها ضرورية في مهنـة الهندسة والرسم الهندسي والتصميم المعمـاري وتصميم الآلات و أعمال التفصيل و غير ها من المهن ـ (الريان، 977 (1) 14 1 )، ومن الاختبار ات التي تقيس هذه القدرة ما ياتٔي أـ اختبار المطابقة : إذ يقدم للمختبر مجموعة من الأشكال ومجموعة أخرى متتـاظرة لها تحتوي على أشكال متطابقة لأشكال المجموعة الأولى غير أن بعضها قد تم تدويره و على المختبر أن يقرن كل شكل مع صورته . بـ اختبار الدوران : إذ يقدم للمختبر شكل وأمامه أربعة أنكال منها واحد فقط يطابق الثكل المعطى غير انه

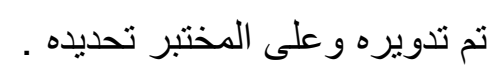

ج- اختبار تجميع الأشكال : حيث يقدم للمختبر شكل أسفل منه مجموعة من الأشكال و عليه تحديد أي مجموعة

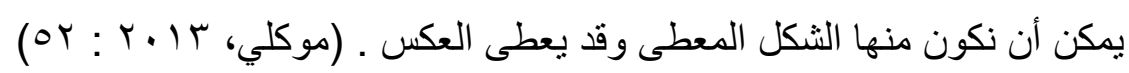
د- اختبار منيسوتا للقطع الورقية : يتألف الاختبار من سلسلة من (ع ) لوحات خشبية يتكون كل منها من (OV) قطعة خشبية مختلفة الأشكال، وبعضها غير مألوف، ويطلب من المفحوص أن يضع هذه القطع في أماكنها في

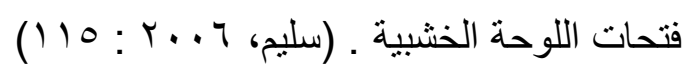

هـ اختبار طي مخطط المكعب : حيث يقدم للمختبر صورة لمكعب وأربعة مخططات لمكعبات غير أن واحداً منها فقط هو الذي يمكن طيه للحصول على المكعب المعطى و على المختبر تحديده : و - اختبار ثقب الورقة المطوية : إذ يقدم للمختبر ورقة نم طيها بأسلوب معين ثم ثقبت في موضـع محدد و على المختبر تحديد مو اضع الثقوب بعد فتح الورقة على وفق مصفوفة من الثقوب وضعت على يمين الورقة . (أبو

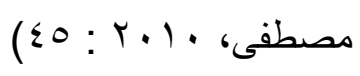

س- اختبار تدوير المكعبات : حيث يقدم للمختبر زوج من المكعبات، ورمزت أوجه المكعبات على أن لا يتثـابه رمز أي وجهين في المكعب الواحد ويطلب من المختبر فيما إذا كان المكعب هو المكعب الأخر ويمثل دور اناً لـه أو انه مكعب مختلف عنه . روتهن فين

ح- اختبار طي الورقة : حيث يتكون الاختبار من قسمين شمل كل قسم عدد من الفقرات بحيث توجد كل فقرة في سطر أفقي، و على يسار السطر الأفقي رسومات متتابعة ومطوية طيتين أو ثناث طيات بحيث تظهر الرسوم الأخيرة للورقة المطوية مكان التقب و على يمن السطر توجد خمس رسومات يفصل بينها وبين الأخرى على لى اليسار خط عمودي ويطلب من المختبر أن يحدد إي واحد من الرسومات الخمس بمثل الورقة المطوية .

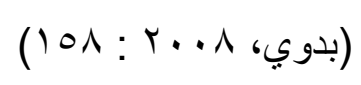

طـ اختبار تكملة الأشكال : وفيه يعرض على المفحوص في هذا النوع من الاختبار ات شكلاً ناقصساً وأمامـه عددُ آخر من الأشكال و المطلوب هو انتقاء الجزء الذي يكمل الثكل الكبير حتى يكون مربعاً أو مستطيلاً. ي- اختبار ات الأشكال المنحرفة : وقد ثبت إن هذه الاختبار ات ذات تشبع عـالٍ بالقدرة الفراغية ـ (السبعاوي، $(\varepsilon \cdot: r \cdot) r$ 
ك- اختبار ات لوح الأشكال : هذا النوع من الاختبار ات يينى على فكرة الاختبار ات العملية للوح الأشكال، ويختلف عنها انه اختبار ورقي يمكن إجر اؤه بطريقة جمعية .

لـ اختبار الأشكال المقلوبة : ويقصد بمقلوب الثكل، الثكل إذا قلب كما تقلب صفحة الكتاب ـ (صـالح، 1911 (097 -090:

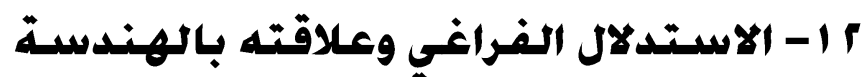

إن الأفكار التي تتضمن تتمية الاستدلال الفراغي تتصل بالموضو عات الهندسية أي وجود نوع من

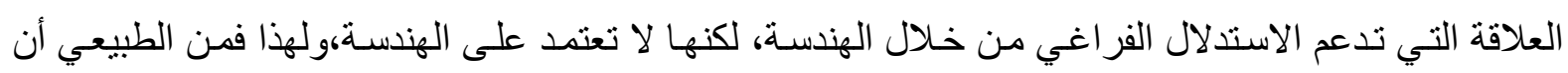

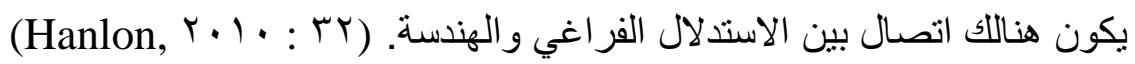

فالهندسة هي در اسة العلاقات الفر اغية، وهي العلاقات التي تكتنف حياتنا من حيث إننا مخلوقات تعبش في المكان الثلاثي الأبعاد (الطول و العرض و الارتفـاع) ففي الملاحـة البحريـة والبريـة والجويـة وفي الهندسـة المعماريـة، وفي الفن نحتـاج إلى هذا التخيل البصـري للأجسـام والعلاقـة بينها حتى عندما تكون بعيدة عنـا، فالمهندس المتمرس يرى واجهة بيت ويستطيع أن يصف للك كيف يبدو البيت من الخلف أو من الجانب، وفي الحساب فضلاً عن الهندسة نسعى دائمساً وهذا دأب الرياضيات الحديثة إلى تصوير الأفكار الحسـابية و إعطائها

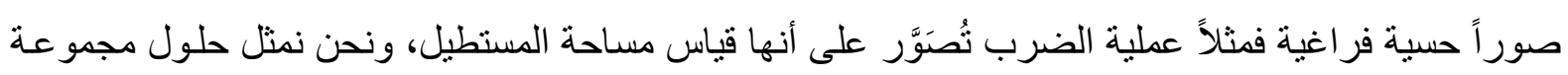

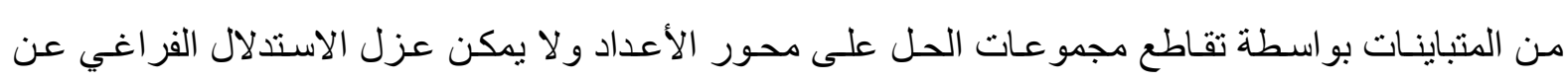

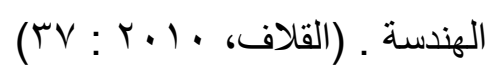

\section{ما - الاسـتدلال الفـراغي والمسيتوى الدراسي للمهعلم}

إن المستوى الدراسي للمعلم ينعكس على تتميـة مهار ات الاستدلال الفر اغي لدى التلاميذ، فقد أشـارت الدراسات إلى إن المستوى الدراسي لدى المعلمين يرتبط بنمو التلاميذ في مهار ات الاستدلال الفر اغي طوال

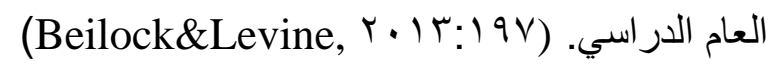

فقد تبين إن التلاميذ في الصفين الأول، والثاني الذين كان لديهم معلمون يتمتعون بمستويات عالية في مجال الاستدلال الفر اغي هم أكثر احتمـالاً في تحقيق مكاسب كبيرة في مهار ات الاستدلال الفر اغي في نهاية

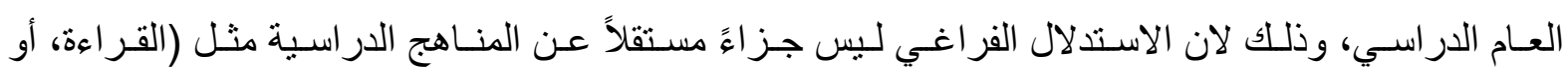
الرياضيات) إذ نجد إن المعلمين الذين يتمتعون بمستويات منخفضـة في مجال الاستدلال الفر اغي قد يتجنبون دمج الأنشطة الفراغية في الفصول الدراسية، كما تم الإشارة إلى أن إحدى الطر ائق لتحسين مهار ات الاستدلال الفر اغي لدى التلاميذ تكون من خلال ما يأني : ا - رفع المستوى العلمي و الدر اسي للمعلمين لتعلم مهار ات الاستدلال الفراغي . r- التأكيد على الحس الهندسي والحس الفراغي . 
في دراسة حديثة أجريت على نطاق واسع في هذا المجال إن بإمكان المعلمين أن يعززوا ويطوروا

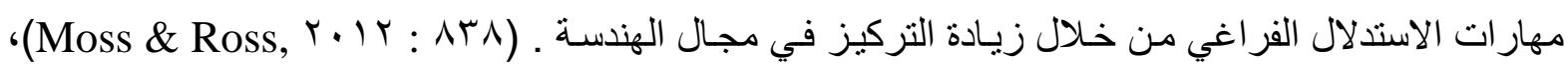
وقدا ظهرت البحوث في أمريكا الثمالية في مجال القدرات الفر اغيـة إن المواضـع المتعلقة بالقدرات الفراغيـة، و الهندسة، والحس الفراغي عادة ما تحصل على وقت واهتمام اقل في الفصول الدراسية من المواضيع الأخرى،

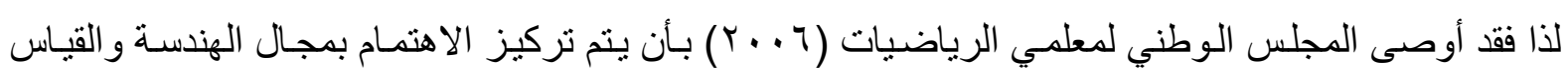

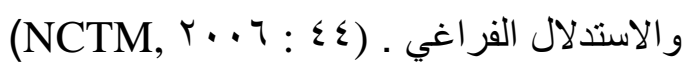

وان الاهتمام والتركيز على الهندسـة وخاصـة الديناميكية والتحويلية (المتعلقة بالأشياء المتحركة) بـلاً

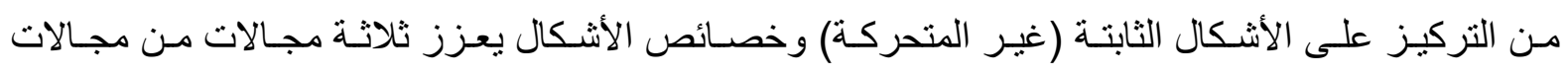

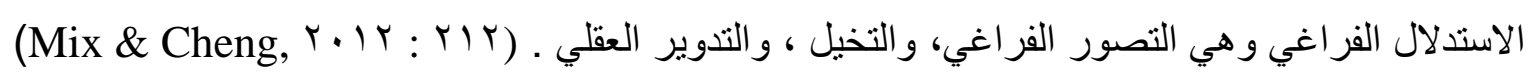
r - التأكد على اللغة الفر اغية، حيث أظهرت الدراسات أهمية ذلك حيث إن استعمال الو الدين للكلمات الفر اغية مرتبط بالقدرة الفر اغية لأطفالهم حيث أظهرت النتائج إن الأطفال الذين يدرسون اللغـة الفر اغيـة أفضل أداء في المهمات الفراغية من الأطفال الذين لا يدرسون ذلك ومن هذه الكلمات كالمسافة والموقع و الاتجاه على سبيل

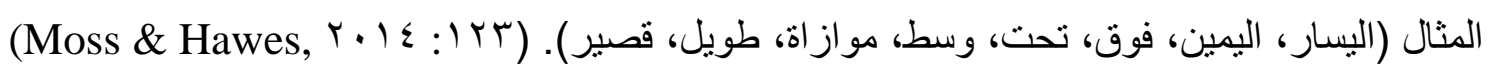

ع ا - نظريات الاستدلال التفراغي : - نظريات النهوذج العقلي : أ - نظرية النموذج العقلي لجنسبون لايرد (Johnson-Laird) النموذج العقلي هو تمثيل للواقع الخارجي بالعقل وكل شيء يتعامل معـه الفرد في الحياة اليومية يُكوّن العقل له نموذج للواقع يمثله في الدماغ، فعندما يتعامل الفرد معه مرة أخرى سيتعامل على وفق النموذج العقلي

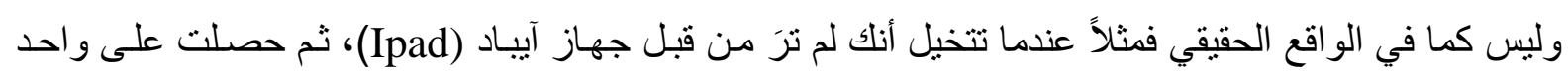
الآن، وقيل للك أنه يمكنك قر اهة الكتب على هذا الآيباد، قبل أن تشـل جهاز الآيباد سيستحضر دماغلك فوراً

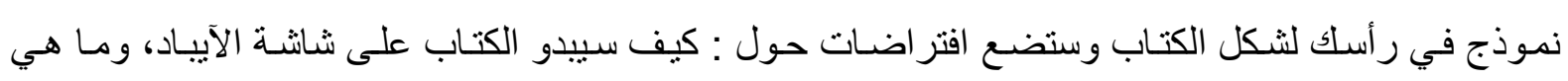
الأشياء التي ستكون قادراً على القيام بها وكيف ستستعمل هذا الآيباد في قر اءة وتصفح الكتاب مثل تقليب الصفحات، كل ما سبق هو نموذج عقلي (Mental Model) لكيفية قر اءة كتاب على آيباد حتى لو لم تكن قد في فئ استعملت آيباد من قبل، أما إذا كنت قد استعملت جهاز آيباد سيكون لديك نموذج عقلي خاص بك من خبرتك في قر اءة الكتب على الآيباد وستكون بالطبع مختلفة عن كل شخص يكون نموذج عقلي خـاص بـه حتى لو كانوا ()http://www.colorslab.net جميعهم يفكرون في الثيء نفسها وفقاً لهذه النظرية فإن الفرد يقوم : أو لاً : ببناء نموذج عقلي لبنية المشكلة . 
ثانياً : قيام الفرد برسم مخطط تلخيصي للمشكلة يعتمد على ذلك النموذج الذي طوره حول المشكلة، ويساعد ذللك النموذج العقلي على جذب المعلومات و التي لا تكون ظاهرة في بنية المشكلة . ثالثاً : قيام الفرد ببناء نموذج عقلي بديل لها يتعـارض نوعاً مـا مـع النموذج العقلي الذي بنـاه أول مره، و إذا لم

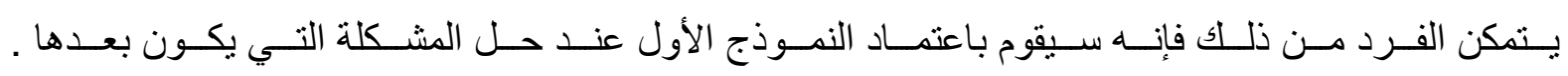

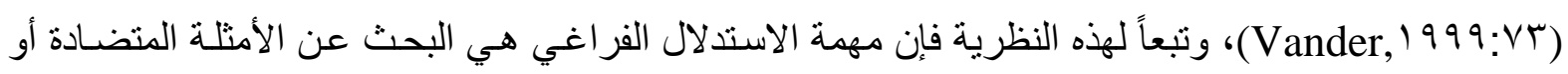

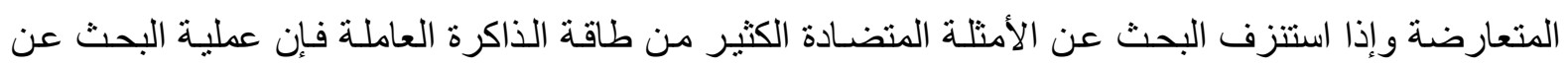

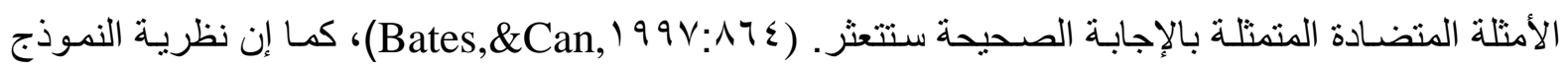
العقلي يمكن ان تتنبـأ بأنسه كلمـا زادت الصـعوبات في المشكلة كلمـا أدى ذلك إلى زيـادة إنتـاج النمـاذج العقليـة وتعرف هذه النظرية الاستدلال الفراغي على انه ليس فقط تصور الأشياء في الفراغ بل هو القدرة على اخذ

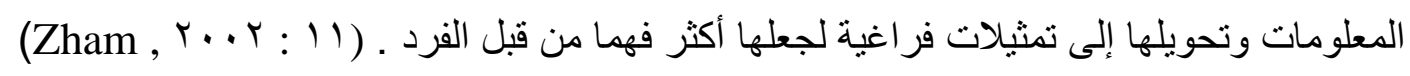

\section{الافتراضسات الرئيسيسية لهذه النظريـة هي :}

ا ـ كل نموذج يمثل إمكانية تو افق أبنيتها الفراغية مع الأبنية المادية في العالم الخارجي . r- كلما زاد عدد النماذج البديلة المطلوبة كلما كان الأمر أصعب .

بـ مبدأ الحقيقة : النماذج الذهنية تمثل فقط ما هو صحيح ومن ثم فهي تتوقع حدوث مغالطات منهجية مقنعة إذا كانت الاستدلالات تعتمد على ما هو كاذب .

عـ النماذج هي أبنية عقلية مبدعه إلى أقصى حد ممكن فهي تكمن وراء الصور المرئية، ولكنها تمثنل أيضـاً

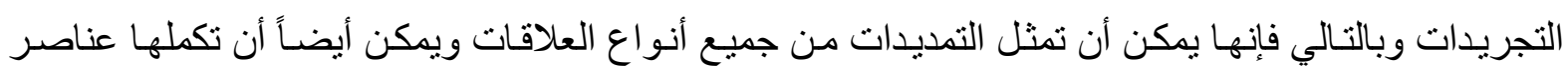

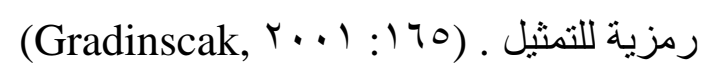

\section{ب- نظريـة النمهوذج العقلي لكريك}

كينيث كريك (r 9 ( ) فكرة مماتلـة كان يعتقد أن العقل يبني "نمـاذج صغيرة الحجم" من الواقع

و التي تستعمل لتوقع الأحداث في العقل لذا فإن النمـاذج الذهنية لها أبنيـة تتو افق مـع الأبنية التي تمثلها ومن ثم

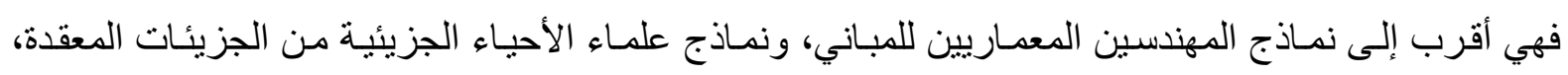
ومخططسات الفيزيائيين لتفاعلات الجسيمات، وقد علم كريك علمـاء النفس المعرفيين أن العقل ييني النمـاذج الذهنية نتيجة التصور و الخيال و المعرفة، وفهم الخطاب وكيف يدرس ويطور الأطفال مثل هذه النمـاذج، وكيفية تصميم القطع الأثرية وأنظمة الكمبيوتر التي من خلالها يتم الحصول على نموذج، وتركز هذه النظريـة على ولى

نوعين من العلاقات في تكوين الاستدلالات الفر اغية هما :

أولاً : العـلاقات الجمردة .

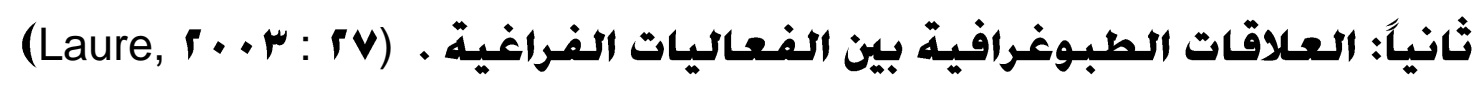

ـ نظرية الاستدلال القاعدة 
إن الاستدلال عن طريق المعلومـات الفراغية يتطلب اختيار الأشكال المناسبة لتمثيل تلك المعلومـات

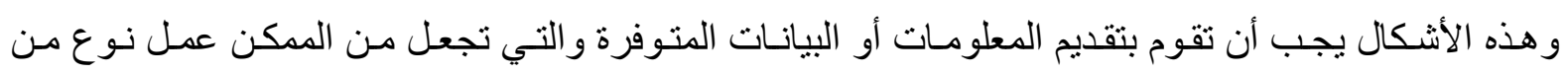
الاستدلال المناسب حولها، وإن العديد من الأعمـال في الاستدلال الفر اغي تعتمد على التمثيلات الفر اغيـة من

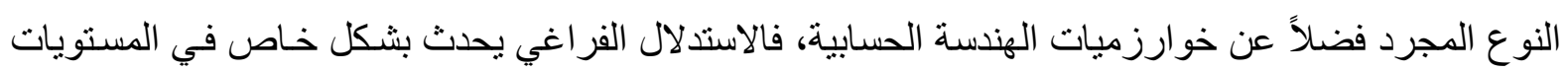
العليا وخصوصاً عندما يتم تطبيق الاستدلال لاكتشاف المسار، ففي بعض الأحيان تكون هنالك حاجة لوصف

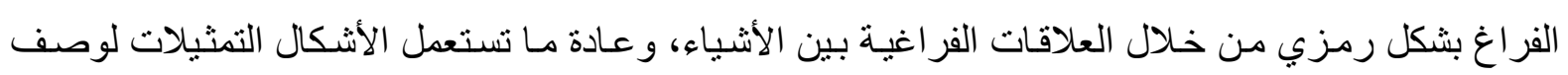
العلاقات الفر اغية المستمدة من الطبقة العليا ضمن التمثيلات الفر اغية من النوع المجرد، وعلى العموم فـإن تلك وعلك

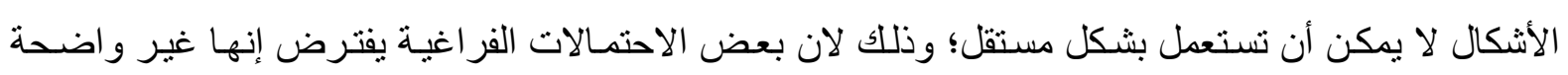
وجلية وتبدو إنها تقع ضمن التمثيلات الثائعة و التي بدور ها تكون بمثابة أرضية لها، ولذلك فإن الاستدلال في مثل هذه العلاقات الفر اغية سيكون صعباً. و الاستدلال وفقاً لنظرية القاعدة يقسم على قسمين :

أ - الاستـدلال العـلائقي : الأنجاه

إن الاتجاه الأول في الاستدلال الفراغي استعمل الاستدلال العلائقي الذي يؤكد على تكامل الاحتمالات الفر اغية الضرورية كافة، و التي يمكن الاستدلال عليها من خـلال الربط بين العلاقات، وان الاستدلال الفراغي لإني يوجد في كل تفاعلاتتـا اليومية مـع العـالم إذ يقع ضمن قدر اتتا على وضـع الخطط وتحديد الفعاليات، وتصسور

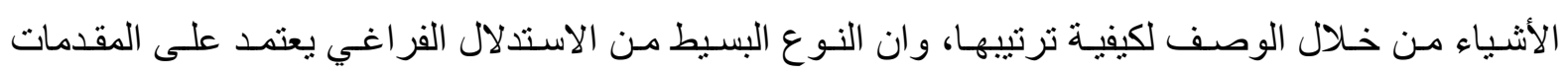

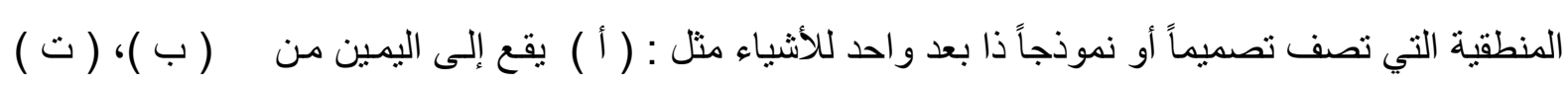

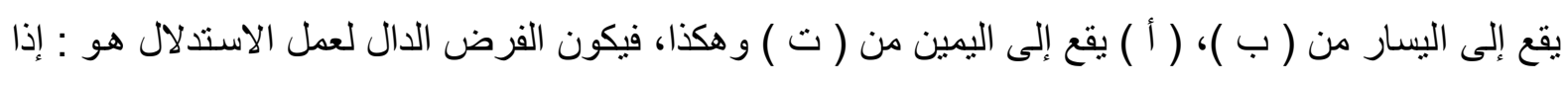
كانت ( س ) تقع إلى اليمين من ( ص )، و( ع ) يقع إلى اليسار من ( ص )، فإن ( س ) ستكون إلى اليمين من

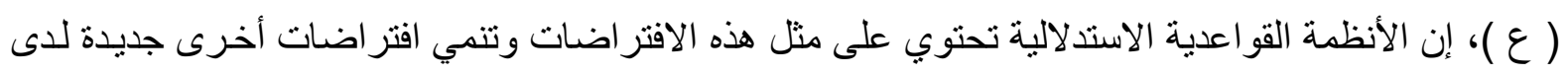

\section{ب - الاستدلال المنطقي :}

هذا النوع من المشكلات يعتمد على المقدمات المنطقية مثنل : (ب ) يقع إلى اليمين ( أ )، ( ت ) يقع إلى اليسار من (ب)، إذ لا تخضع تلك المقدمات إلى أي تلخيص واضـح وبـارز للعلاقة بين ( أ ) و ( ب )، و وان تللك المقدمات المنطقية تفثل في مطابقة أي من الأحكام الثكل في النظام، وهكذا فإن الاستجابة ستكون خالية

$$
\text { أي تلخيص صادق أو واضح وبارز . }
$$

إن هذه النظرية تنبأت بأن الأفر اد سيجدون من السهل التعامل مع المشكلة الأولى مقارنـة بالثانيـة،

و ان النموذج المعتمد على هذه النظرية يتيح عمل تتبؤات مشابهة لتلك المشكلة البسيطة ولكن بشكل مختلف قليلا

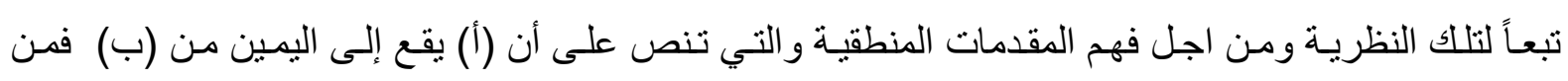
الضروري إدر الك معنى الاستدلال العلائقي الذي هو (أ) يقع إلى اليمين من (ب) وان هذه المعلومـة تعمل سوية

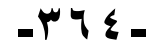


مع المبادئ التركيبية، والتي تربط المعاني تبعاً لعلاقاتها النحوية التي يمكن أن تستعمل في بناء تمثيلات للموقف الخاص بالمقدمة المنطقية، وإن اغلب البرامج الحاسوبية التي تعمل على وفق هذه النظرية تقوم ببنـاء مستقيمات

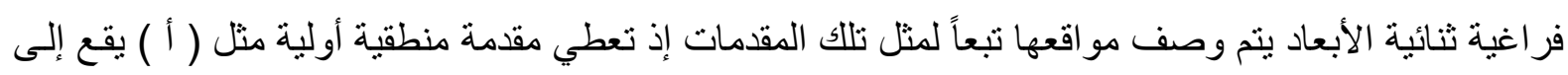

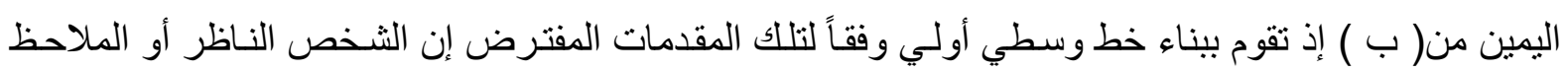

يقف أمام نلك الأشكال . (Byrne, 1919 :070)

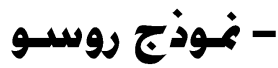

أثنار روسو إلى وجود مساحات في الدماغ تظهر أنواع مختلفة من الاستدلال الفر اغي، إذ تبدو أن تلك الأنواع تتطور في عمر مبكر، وتميل إلى أن تتكامل خلال الحياة، وقد حدد روسو ثلاثنة مر احل رئيسية لتطور

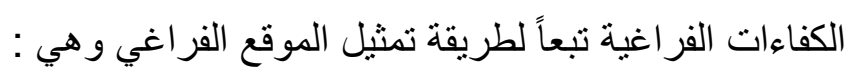
ا ـ التمثيل الذاتي : ويكون ذو علاقة بأنفسنا ومواقعنا الخاصة . r - التمثيل المعلمي : وهو ذو علاقة بالمعالم الرئيسية في البيئة . ب - التمثيل الكلي المركزي : وذلك مـن خـلال استعمال الإطسار العـام للاستـلال مثنل الخر ائط و التتسيقات فالرضع مثلاً يدركون ويفهمون الفراغ بطريقة ذاتية متخذين من أنفسهم مركز اً لهذا الفهم، وقد أنشارت البحوث و الدر اسات إلى إن الصغار من عمر (ب - ؟) أثهر يفهمون مفاهيم مثل (فوق، تحت، يمين، يسار) فعندما يقوم الطفل باكتشـاف العـالم من خـلال (الحبو) فهم يفعلون أو ينشطون أيضـاً عمليـة التخطيط المعرفي ويطورون

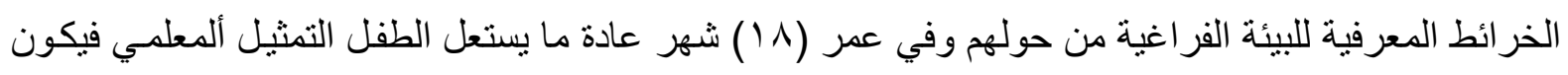
قادراً على استعمال الخصائص الموجودة في المحيط وذلك لإعـادة توجيـه أنفسهم، أمـا التمثيل الكلي المركزي فيتطور لاى الأطفال في عمر (ع) سنوات فيكونون قادرين على استعمال الخرائط البسيطة في إيجاد طريقهم فهم بإمكانهم أن يختصروا الرموز المختلفة التي تمثل الأشياء الخاصـة في العـالم الحقيقي مثنل الطرق والأنهار

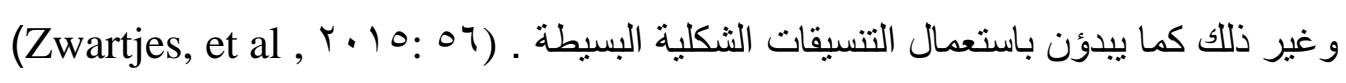

\section{(الفصل الثالث) الدراسـات السـابقة}

تُعّد عملية استعر اض الدراسات السابقة خطوة مهمة في البحث العلمي، فهي تُمكّن الباحث من معرفة موقع در استه من بين الدر اسـات التي سبقته، وتُسـاعد في اختيار منهج البحث و العينـة والأسـاليب الإحصـائية المناسبة من اجل الحصول على النتائج وتفسير ها، وفيما يأتي عرض للار اسـات التي استطاع الباحث الحصول عليها وبحسب متغير ات البحث:

\section{دراسـات الاستـدلال الفراغي :}

$$
\text { در اسات عربية : }
$$

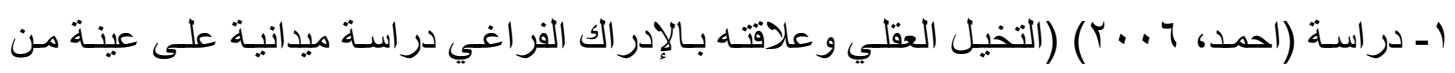
طلاب كلية الهندسة الميكانيكية) أجريت هذه الدر اسـة في سوريا، وهدفت إلى الكثف عن العلاقة بين الأداء 
على اختبار التخيل العقلي و الأداء على اختبار الإدر الك الفر اغي لدى عينـة من طلبـة كلية الهندسـة الميكانيكية، و هدفت أيضاً إلى معرفة الفروق بين الذكور والإنـاث في أدائهم على اختبار التخيل و الإدر الك الفراغي، وقد

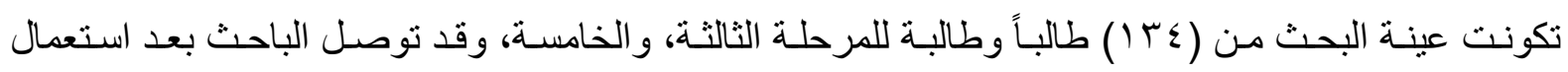
الوسائل الإحصائية إلى النتائج الآتية :

ا ـ وجود علاقة ارتباط ايجابية ذات دلالة إحصـائية بين متوسط درجات الأداء على اختبار التخيل ومتوسط

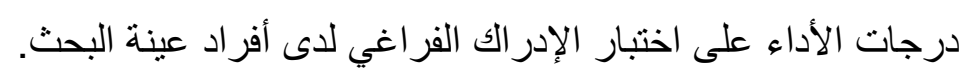

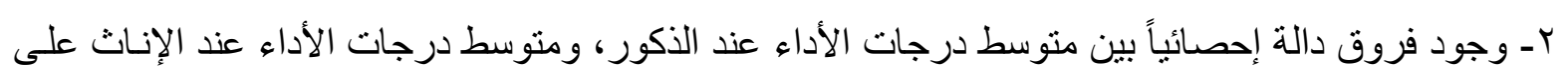
اختبار الإدراك الفر اغي لصـالح الذكور، في حين لم يكن هنـالك فرق في متوسط درجـات الأداء على اختبار التخيل .

بـ عدم وجـود فروق في متوسط درجـات الأداء على اختبـار التخيل ومتوسط درجـات الأداء على اختبـار

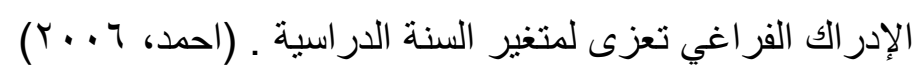

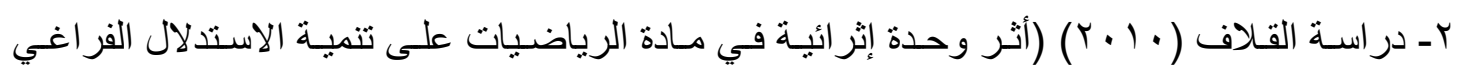
وتحسين التحصبل في الهندسـة لدى تلميذات الصف الخـامس الابتدائي) و أجريت هذه الدراسـة في الكويت، و هدفت إلى التحقق مـن فاعليـة وحدة إثر ائيسة في مـادة الرياضـيات على تنميـة الاســدلال الفر اغـي وتحسين التحصيل في الهندسـة للى تلميذات الصف الخـامس الابتدائي، وقد استعملت الباحثة في هذه الدراسـة المنهج

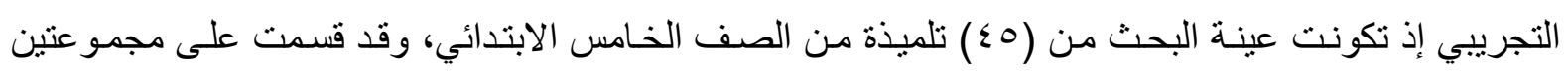

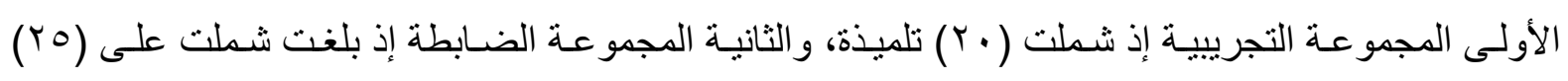
تلميذة، استعطلت الباحثة اختبار الاستدلال الفراغي و هو من تأليف نيفر نيلسون (Nfer Nelson) و التي قامت الباحثة بإعداده حيث ترجمته إلى اللغة العربية الذي تكون من أربعة مجالات وهي : (تدوير الأشكال، وتكبير الأشكال، التشكيل، تدوير الأشكال المسطحة)، واختبـار الهندسـة، وبعد تطبيق الاختبـارين على أفراد العينـة (اختبـار قبلي)، تم تطبيق وحدة إثرائيسة في مـادة الرياضيات على التلميذات، ومن ثم تطبيق(اختبـار بعدي) للاختبارين، وتم التوصل بعد استعمال الوسائل الإحصائية إلى النتيجة الآتية : يؤدي تطبيق وحدة الإثرائية في

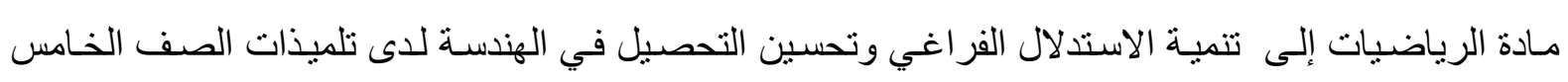
الابتدائي . ملادهاصي

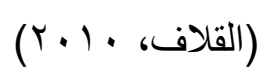

\section{دراسات أجنبية :}

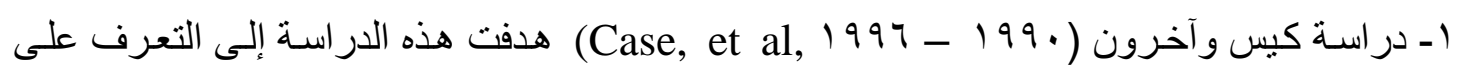
طبيعـة نمو الاستـلال الفر اغي لدى عينة مـن الأطفال من عمر (عـ - ( ) سنوات، وقد توصلت الدراسـة بعد 
استعمال الوسائل الإحصائية إلى ما يأتي : الكثف عن وجود أربع مراحل تميز نمو الاستدلال الفراغي لدى

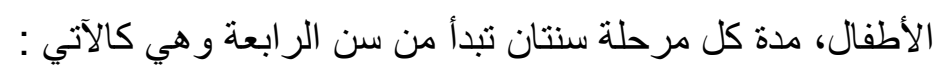
ا - رسوم مـا قبـل المحاور عمر(ع) سنوات : حيث يمثل الطفل ويصـور الأشكال المكونـة للثـيء ومواضـع الأشياء في مجال مستطيل . التوم مساء

ז- الرسم أحادي المحور عمر(7) سنوات : حيث يمكن للطفل أن يعين الأشكال الداخليـة للشـيء و العلاقات الداخلية فيه وموضعه بالنسبة للمجال . r- الرسم ثنائي المحورين عمر (^) سنوات : حيث يضع الطفل عقلياً مجالين منفصلين داخل المجال الرئيس في العادة مقدمة وخلفية وبالتالي يستعطل خطي إثارة منفصلين للارتفاعات . عـ الرسم ثنائي المحورين المدمجين عمر ( • () سنوات : إذ يناست الطفل المجال ككل مع استعمال المحورين الأفقي والر أسي كإنشار ات أو مرجعيات وتحتوي الرسوم على منطقة وسطى تربط المقدمة والخلفية ـ نقلاً عن

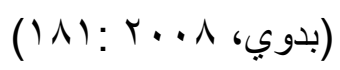
r- در اسة وانغ (Wang, 1991) (قدرات الاستدلال الفر اغي لدى التلاميذ الموهوبين) هدفت هذه الدراسـة إلى

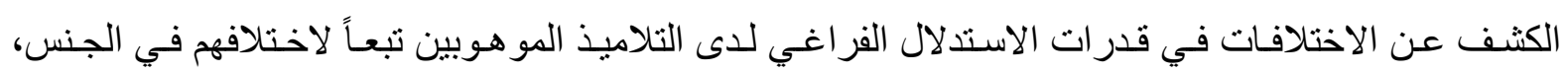
وتكونت عينـة البحث من (rT) تلميذاً بصفتهم تلاميذ مو هوبين أكاديمياً من اجل البحث في نتائجهم الثفوية

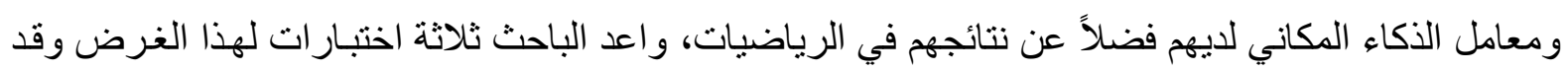
توصل الباحث بعد استعمال الوسائل الإحصائية إلى النتائج الآتية : ا ـ أسلوب أداء التلاميذ الموهوبين من ذكور على اختبار الاستدلال الفر اغي لم يكن مختلفاً بشكل كبير. ك- قدرات الاستـلال الفر اغي لدى التلاميذ الذكور أعلى منهـا لدى التلميذات الإنـاث في المهمـات المتعلقـة بالقدرات الخاصة (التركيب، وتسلسل الأرقام) مما يدل على أنها مرتبطة باختلاف الجنس . (Wang , 1991$)$

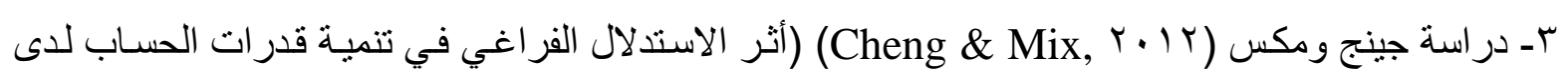
الأطفال)هدفت هذه الدراسة إلى التعرف على أثر الاستدلال الفر اغي في تتمية قدرات الحسـاب لدى الأطفال في

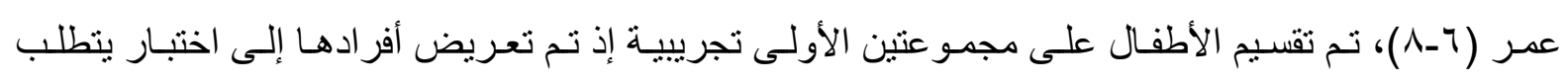

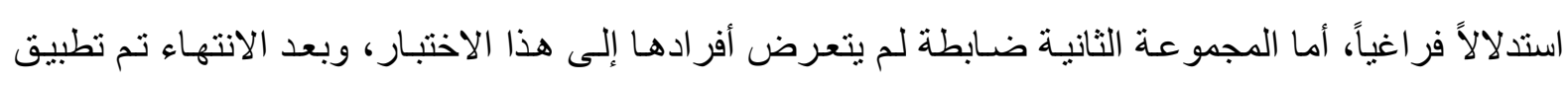

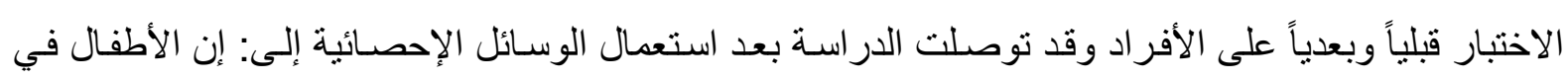

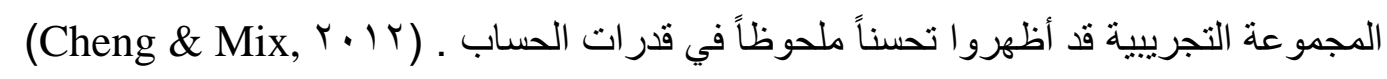

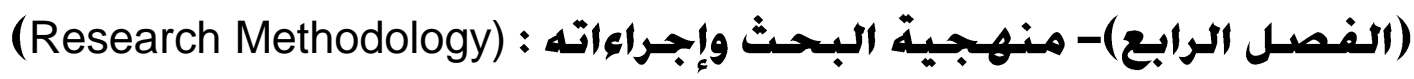

يتضمن هذا الفصل عرضاً للإجر اءات التي تم إتباعها في هذا البحث و التي تعمل على تحقيق أهدافه ابتداءً من تحديد منهج البحث، ومجتمعه وعينته و انتهاءً بالوسائل الإحصائية و على النحو الآتي : 
أولاً : منهج البحثث (Method of the Research)

منهج البحث المتبع في هذا البحث هو المنهج الوصفي، بوصفه من أكثر المنـاهج استعمالاً في دراسـة

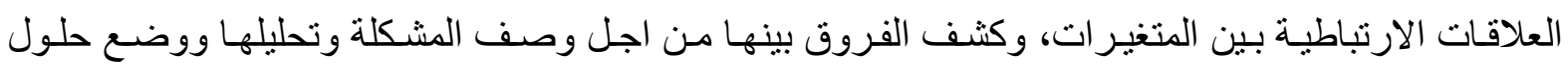
للظـاهرة المدروسـة بأسلوب منظم ودقيق وبطريقة منهجيـة موضو عية صـادقة ممـا يحقق أهداف البحث، ولهـ

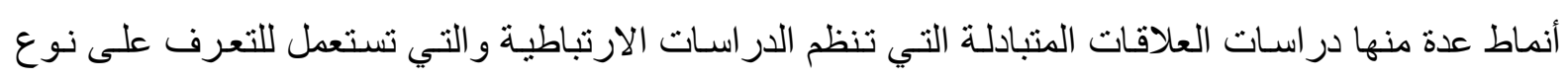

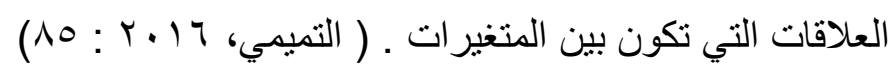
و المنهج الوصفي من الأساليب المتبعة في البحث العلمي التي تهتم بدر اسة الظاهرة كما هي في الواقع،

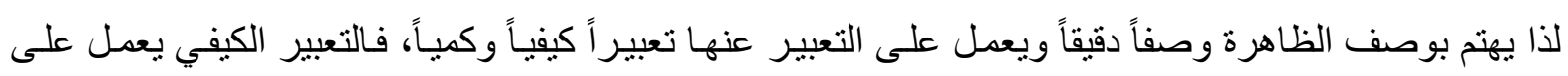
وصف الظـاهرة ويوضـح خصائصهـا أمـا التعبير الكمي فهو يعطي وصفاً رقمياً يوضـح مقدار هذه الظـاهرة

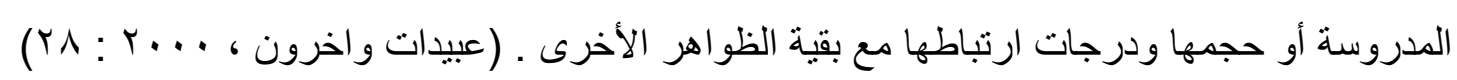
كمـا يزود المنهج الوصفي البـاحثين بالمعلومـات الدقيقة والقيمـة التي تعبن على فهم الحاضـر، وفهم

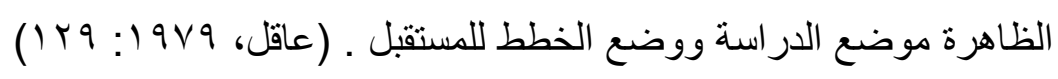

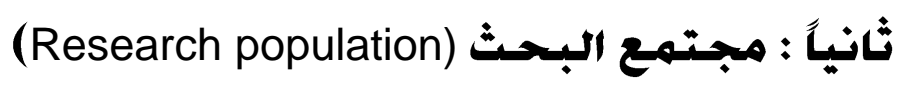

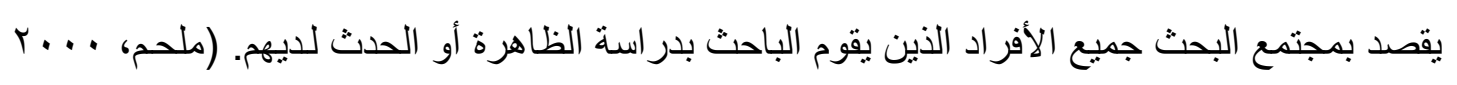

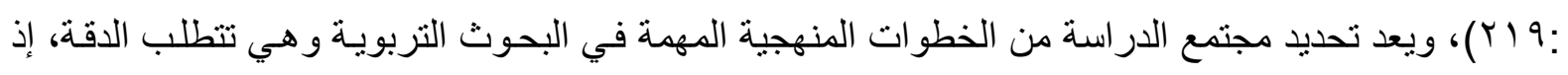

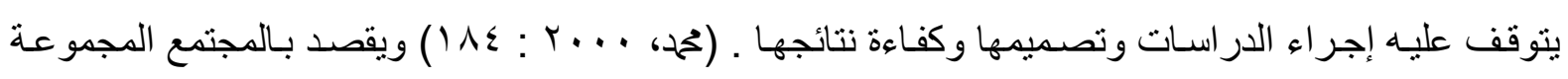

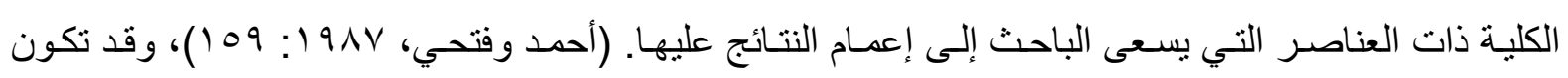
مجتمع البحث الحالي من طلبـة الصف الخـامس في المدارس الإعداديـة والثانويـة الحكوميـة في مركز محافظـة

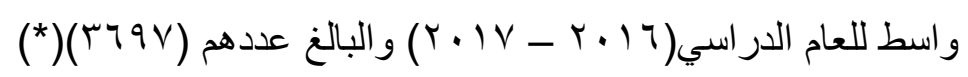

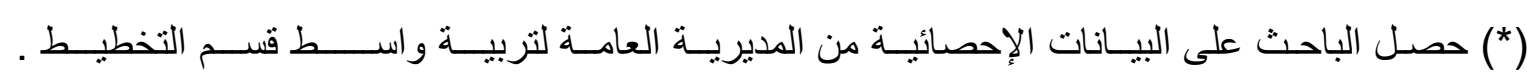

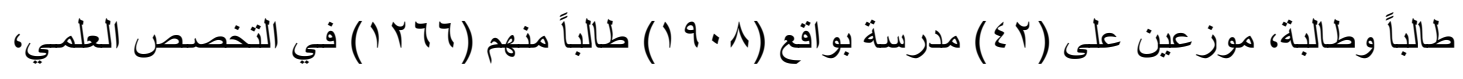

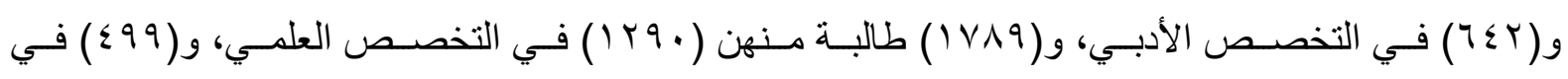
التخصص الأدبي والجدول ( ( ) يوضح ذلك . جدول ( ) إ) مجتمع البحث موزع بحسب الددارس والجنس و التخصص

\begin{tabular}{|c|c|c|c|c|c|c|c|}
\hline \multicolumn{3}{|c|}{ الخامس الادبي } & \multicolumn{3}{|c|}{ الخامس العلمي } & \multirow[t]{2}{*}{ اسم المدرسة } & \multirow[t]{2}{*}{ ت } \\
\hline مجموع & بنات & بنين & مجموع & بنات & بنين & & \\
\hline$\$ 4$ & 24 & $\overline{-1}$ & 11. & 11. & $\overline{-1}$ & إعدادية اليسـر للبنات & 1 \\
\hline 11 & 11 & - & 71 & 11 & 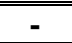 & إعدادية الهـى للبنات & $r$ \\
\hline
\end{tabular}




\begin{tabular}{|c|c|c|c|c|c|c|c|}
\hline rq & rq & - & 91 & 91 & - & إعدادية المـودة للبنات & $r$ \\
\hline$\overline{r \Lambda}$ & $\overline{Y \Lambda}$ & - & 1.9 & 1.7 & - & إعدادية الزهراء للبنات & $\overline{c \varepsilon}$ \\
\hline - & - & - & 119 & 117 & - & إعدادية الكوت للبنات & 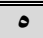 \\
\hline - & - & - & IVo & - & IVo & إعدادية الكـوت للبنين & 7 \\
\hline VV & - & VV & 10. & - & 10. & إعداديةٌ الكرامةٌ للبنين & $\mathrm{V}$ \\
\hline 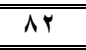 & - & AY & 101 & - & 101 & إعداديـة المثنى للبنين & 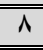 \\
\hline$\varepsilon \wedge$ & - & \&1 & $\overline{4 r}$ & - & $\overline{T H}$ & إعداديـة دجــــــة للبنين & 99 \\
\hline 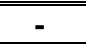 & - & - & $\overline{P \cdot r}$ & - & $\overline{Y \cdot r}$ & إعداديـة الحمـزة للبنين & 1. \\
\hline$r \Lambda$ & $r_{\mu}$ & - & Or & Or & - & إعداديـة النـــور للبنـات & 11 \\
\hline$\$ 7$ & $\leqslant 9$ & - & $10 Y$ & $10 Y$ & - & إعدادية الغذير للبنات & IY \\
\hline$r$. & r. & - & VI & VI & - & إعدادية الزاكيات للبنات & 14 \\
\hline - & - & - & \&r & \& & - & إعدادية الفاضلات للبنات & $1 \leqslant$ \\
\hline \&Y & \&Y & - & 29 & $\overline{19}$ & - & إعدادية ذات النطاقين للبنات & 10 \\
\hline r. & r. & - & 11. & 11. & - & إعدادية خوله بنت الازور للبنات & 17 \\
\hline$\varepsilon V$ & - & $\varepsilon V$ & 00 & - & 00 & إعدادية الكوت المســائيسة للبنيــن & $\overline{T I V}$ \\
\hline$P \leqslant$ & 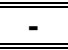 & Yध & \&ई & - & \&ई & إعداديـة الإمام الرضا ع للبنين & 11 \\
\hline IV & - & IV & IV & - & IV & إعدادية المصطفى للبنيـن & 19 \\
\hline$\overline{~ A r}$ & - & $\Delta \mathrm{NH}$ & IVY & - & IVY & إعدادية المـيمــون للبنـين & $r$ r. \\
\hline $9 \mathrm{~V}$ & - & $9 \mathrm{~V}$ & - & - & - & إعدادية ؛ ا تمـــوز للبنين & YI \\
\hline$r \Lambda$ & - & rर & - & - & - & إعدادية سيد الاتسام للبنين & YY \\
\hline 0. & - & 0. & - & - & - & إعداديــة الـسبياب للبنيــن & $r r$ \\
\hline 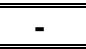 & - & 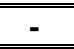 & $10 \leqslant$ & 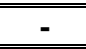 & $10 \%$ & إعداديـــة العزةة للبنيـن & $Y \varepsilon$ \\
\hline - & - & - & $\overline{~ r \Lambda}$ & ri & - & إعداديــة الشهيدا نـــزار للبنـات & ro \\
\hline$\overline{\mid c Y}$ & EY & - & \&4 & \&4 & - & ثنانوية الــــــــاطميـــات للبنـات & $\overline{Y 7}$ \\
\hline$\overline{11}$ & rI & - & - & - & - & ثانوية الكــريمــــــــة للبنات & $\overline{r V}$ \\
\hline 1. & $r$ & $\mathrm{~V}$ & & & - & ثُانوية عشتارة المختلطة & $r \wedge$ \\
\hline Yo & ro & - & $\Lambda \varepsilon$ & $\Lambda \varepsilon$ & 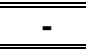 & ثانوية البتــــــول للبنـات & rq \\
\hline - & - & - & - & - & - & ثانوية العذراء للبنات & r. \\
\hline \&1 & « & - & ro & ro & - & ثثانوية المنار للبنات & $\mu_{1}$ \\
\hline - & 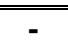 & 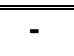 & 17 & 19 & 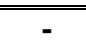 & ثُانوية الرباب للبنات & $\overline{r r}$ \\
\hline ro & ro & - & - & - & - & ثنانويةٌ التأميم للبنات & $\overline{r r}$ \\
\hline 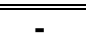 & 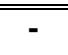 & 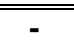 & $\overline{r v}$ & $\overline{r v}$ & 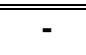 & ثانوية العــزة للبنات & $\overline{r \varepsilon}$ \\
\hline - & 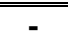 & - & 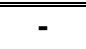 & 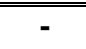 & 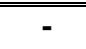 & ثانوية المركزية للبنات & ro \\
\hline 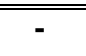 & $\overline{-}$ & 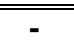 & 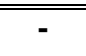 & 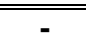 & 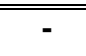 & ثانتوية القاســــم للبنيـنـن & $r 4$ \\
\hline 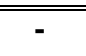 & 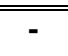 & 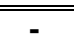 & \&. & \&. & 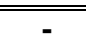 & ثُانوية المتميزين للبنين & $\overline{r v}$ \\
\hline$\overline{r V}$ & 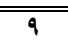 & 11 & - & - & - & ثنانوية الأعراف المختلطة & $\overline{r \Lambda}$ \\
\hline 1. & 1. & - & - & - & - & ثُانوية الكوت المسائية للبنات & rq \\
\hline - & - & - & 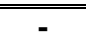 & 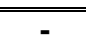 & - & ثُانويةٌ حسن شحاتة المختلطة & \&. \\
\hline IV & 7 & 11 & \&0 & Ir & Tr & ثانوية دعبل الخزاعي المختلطة & \&1 \\
\hline \&r & - & \&r & - & - & - & ثُانوية الثُهـيد أبو كوثــر الزيدي & $\overline{\varepsilon \varphi}$ \\
\hline $11 \leqslant 1$ & $\leqslant 99$ & $\bar{T} T \leq Y$ & ro04 & 1rq. & $1 \times 49$ & المجمـــوع الكلــــي & \\
\hline
\end{tabular}

ثالثًا : عينة البحث (Research Sample)

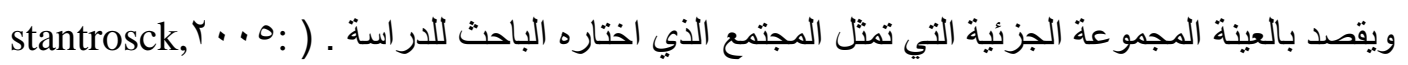

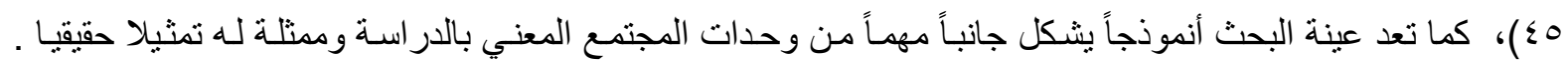

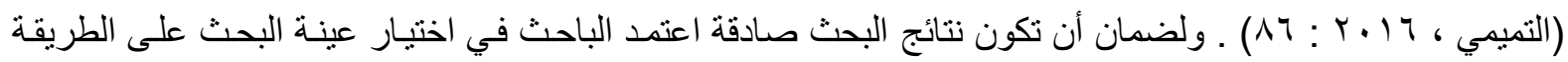
الطبقية العشو ائية، ويستعمل هذا الأسلوب في حال كان مجتمع البحث غير متجانس وبالإمكان تقسيمه إلى طبقات منفصلة 
على وفق متغير الجنس وعدّ كل طبقة وحدة واحدة، وبعدها يتم اختيار أفر اد عينـة البحث بصورة عشو ائية من هذه

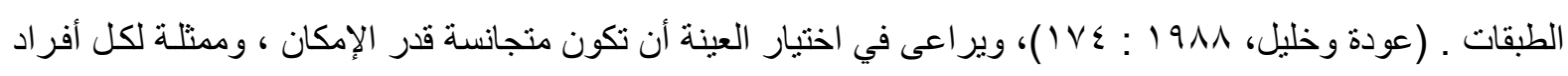

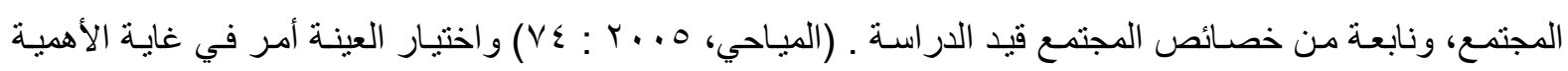

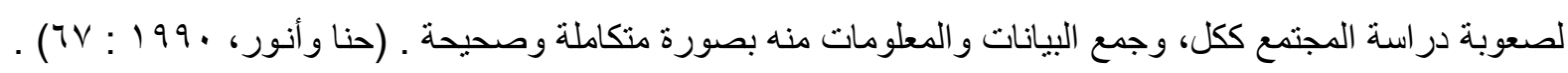

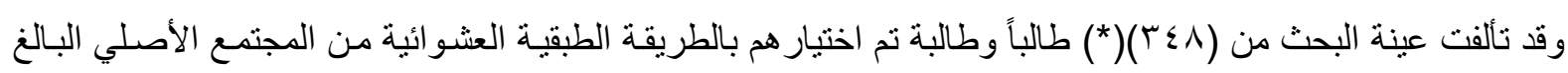

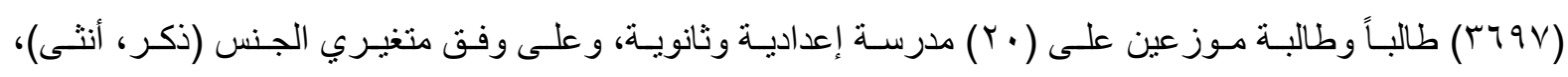

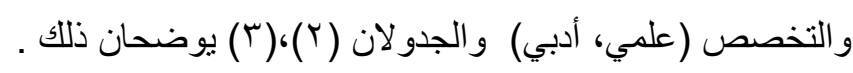
جدول (r) عينة البحث موزعة حسب النسب

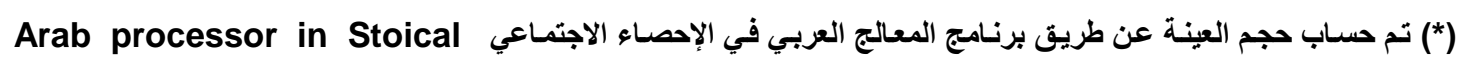
Statistics (APSS 1.·) جدول (r) عينة البحث موزعة حسب الجنس و التخصص

\begin{tabular}{|c|c|c|c|c|c|}
\hline \multirow{2}{*}{ المجموع } & \multicolumn{2}{|c|}{ أدبي } & \multicolumn{2}{|c|}{ علمي } & \multirow{2}{*}{ الفئة } \\
\hline & الإناث & الأذكور & الإناث & الذكور & \\
\hline $1, \cdots$ &., 10 & $\cdot, 17$ & $\cdot, \pi \mu$ &., $4 \pi$ & النسبة \\
\hline 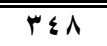 & 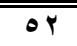 & 89 & 1117 & $\bar{~} 1 Y \xi$ & العدد \\
\hline
\end{tabular}


رابعاً : أدوات البحث (Instrumentation)

\begin{tabular}{|c|c|c|c|c|c|c|c|}
\hline \multicolumn{3}{|c|}{ الخامس الأدبي } & \multicolumn{3}{|c|}{ الخامس الطلمي } & \multirow[t]{2}{*}{ اسم المدرسة } & \\
\hline 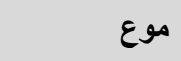 & 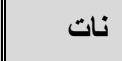 & نين & 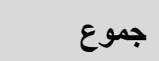 & نات & نين & & \\
\hline 1. & 1. & - & 10 & 10 & 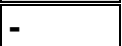 & إعدادية اليسر للبنات & \\
\hline 0 & 0 & - & 10 & 10 & - & إعدادية الزاكيات للبنات & \\
\hline$\overline{-1}$ & - & - & 10 & 10 & 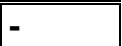 & إعدادية الفاضـلات للبنات & \\
\hline 0 & 0 & - & 10 & 10 & - & إعدادية خولة بنت الازور للبنات & \\
\hline- & - & - & 10 & 10 & - & إعادية الشهيد نزار للبنات & \\
\hline 0 & 0 & 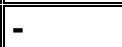 & $\overline{-1}$ & 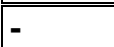 & 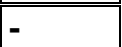 & ثُانــويـــة الكريمية للبنات & \\
\hline - & 0 & - & - & - & - & ثثانويــــة التأميـــــم للبنات & \\
\hline- & - & - & 11 & 11 & & ثانويـــة ألعــــــزه اللبنات & \\
\hline 1. & 1. & - & 10 & 10 & 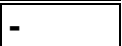 & لثانويــة المــــار للبنات & \\
\hline 0 & 0 & - & 10 & 10 & - & ثاناتوبية البــــول للبنات & - \\
\hline 1. & - & 1. & r. & $\overline{-}$ & $\%$ & إعدادية المثنى للبنين & 1 \\
\hline - & - & - & $r$. & - & 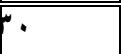 & إعدادية الحمــزة للبنين & $r$ \\
\hline 1. & - & 1. & 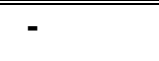 & - & - & إعادية العـــياب للبنين & $\bar{r}$ \\
\hline$\overline{-1}$ & - & - & $r$. & 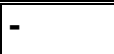 & 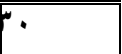 & إعدادية العـــزة للبنين & $\varepsilon$ \\
\hline 7 & - & 7 & $\overline{-}$ & 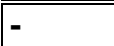 & 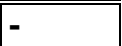 & إعدادية ســيا الانام للبنين & (0) \\
\hline$\overline{1 .}$ & - & . & ro & - & ro & إعدادية الكوت المسائية للبنين & 7 \\
\hline 0 & - & 0 & $\overline{-1}$ & 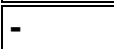 & - & ثُانوية الثهيه أبو كوثر الزيــاي & v \\
\hline$\overline{T r}$ & r & 1. & $\overline{-1}$ & $\overline{-1}$ & $\overline{-1}$ & 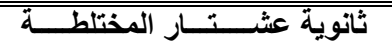 & $\Lambda$ \\
\hline 1. & 0 & 0 & - & - & - & ثانانوية الأعـــــــراف المختلطة & 9 \\
\hline- & - & - & 9 & - & 9 & ثُانوية دعبل الخزاعي المختلطة & . \\
\hline 1.1 & Pr & 87 & $r \leqslant$. & 17 & $r \varepsilon$ & المجموع الكلي & \\
\hline
\end{tabular}

لتحقيق أهداف البحث ولغرض قياس متغير البحث، تطلب الأمر ما يأتي :

تبني اختبار للاستدلال الفراغي . 


\section{اختبار الاستـدلال الففراغي}

بعـد اطـلاع الباحـث على العديـد مـن الأدبيـات و الدر اسـات السـابقة الخاصـة باختبـار الاسـتـلال الفراغي، وجد الباحث إن مكونات الاختبار تتشابه إلى حد كبير مـع مكونـات اختبار التدوير العقلي الذي أعدته لــ

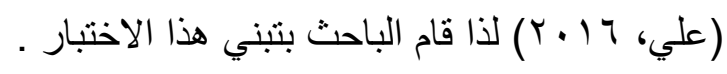

\section{ا - وصسف الاختببار :}

اعتمد الباحث تعريفاً نظرياً لـ كليمنس وباتيستا (Clements\&Battista, 1994) و الذي عرفه

بأنه (مجموعة من العمليات الذهنية التي يتم عن طريقها تمثيل الأشكال فر اغياً وإدر اك العلاقات بينها، و إجراء

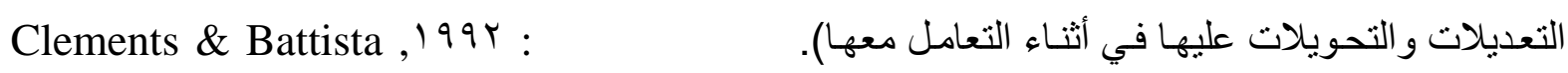

ويتكون الاختبار من (1 ( ) فقرة موزعة بالتساوي على ستة مجالات وهي :

اـ التدوير الر أسي : و هو التدوير الذي يتتاول تصور الأشكال من الأعلى أو الأسفل .

r- التدوير المحوري : وهو تصـور الأشكال من خـلال تدوير ها بشكل محوري إلى الجوانب باتجـاه

عقارب الساعة .

بـ تدوير الأشكال المسطحة ذات البعد الواحد : وهو تصـور الأشكال بعد تدويرها بصـورة دائريـة

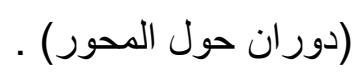

ع - التشكيل : وهو تصور الأشكال في حالة تفكيك الأشكال إلى أجزائها أو تجميعها من أجزائها .

$$
\text { هـ التدوير الثلاثي الإبعاد : وهو تصور الأشكال في حالة تدوير ها باتجاهات حرة . }
$$

7ـ التصـغير والتكبير : وهو تصـور الأشكال في حالـة تصـير الثـكل الأساسي أو تكبيرة أو تغيير

اتجاهاته أو بعض تفاصيله .

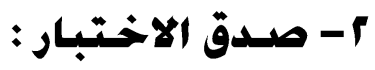

يمتلك الاختبار الصدق الظاهري إذا كان مظهره يدل على انه يقيس الغرض الذي وضع من اجله،

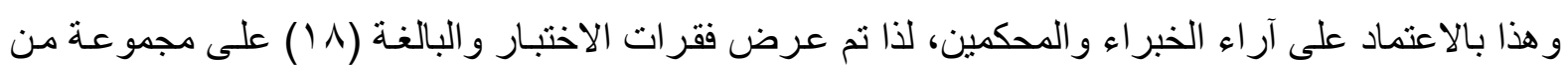

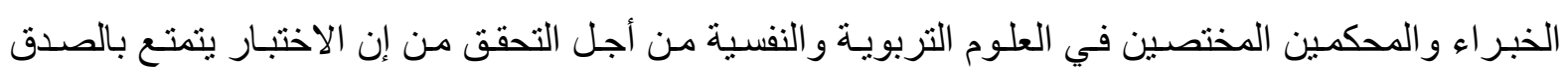

الظاهري لقياس ما وضع لقياسه لذا طلب منهم إبداء آر ائهم وملاحظاتهم من حيث : أ - الحكم على صلاحية كل فقرة من فقرات الاختبار .

بـ الحكم على صلاحية منطقية الحلول المقترحة كمفتاح تصحيح الفقرات .

ج - - الحكم على ملائمة الفقرة للمجال الذي يقيسها . 


\section{د - الحككم على وضـوح تعليمات وأمثلة الاختبار ومدى ثخقيقها للغرض المطلوب}

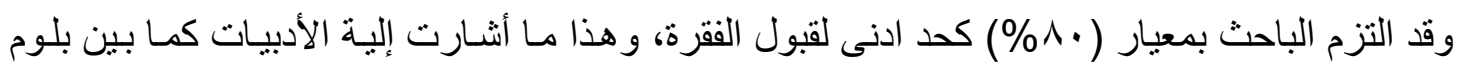

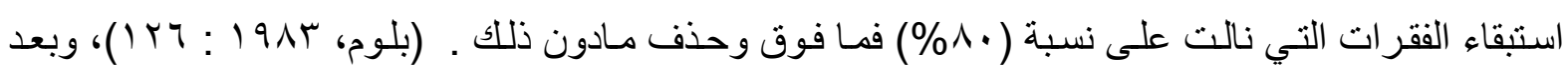
اطلاع الباحث على آراء وملاحظات الخبر اء والمحكمين، أخذ الباحث بجميع التعديلات والتصحيحات اللغويـة التي تم الإشارة إليها من قبل الخبر اء و المحكمين على فقرات الاختبار ، وقد وجد الباحث أن فقرات الاختبـار قد حصلت على مو افقة جميع السادة الخبر اء و المحكمين وبهذا أصبح الاختبـار جـاهزاً لعرضـه على عينـة البحث الاستطلاعية من اجل التعرف على وضوح تعليمات الاختبار وفقر اته .

\section{با العينة الاسمتطلاعية:}

يهدف الإجراء إلى التعرف عن مدى وضوح تعليمـات الاختبـار وفقراته وبدائلـه، و الكثف عن

فقر ات الاختبار التي تتصف بالغموض أو بضعف الوضوح لأفر اد عينة البحث والعمل على تعديلها، ومن ثم القيام بحساب مدى الوقت المستغرق في الإجابة عن فقرات الاختبـار، الأمر الذي يحقق مدى فهم أفراد العينة

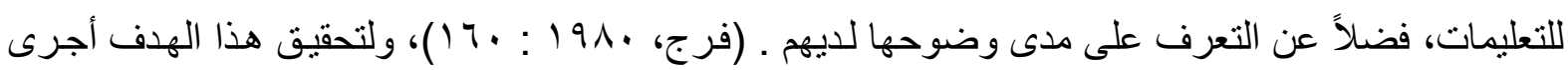
الباحث تطبيقاً استطلاعياً للاختبار على عينة بلغت ( • (7) طالباً وطالبة وكما موضح في الجدول (ع)، وقد تبين للباحث أن فقر ات الاختبار، كانت واضحة لدى أفراد العينة، وفيما يخص الوقت المستغرق للإجابـة عن فقرات

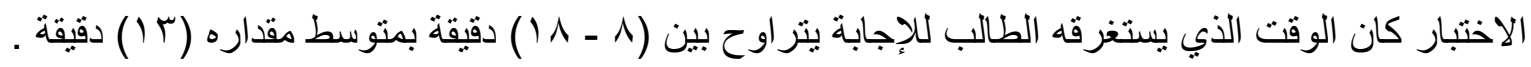
جدول (乏) عينة النطبيق الاستطلاعي الأول

ء التحليل

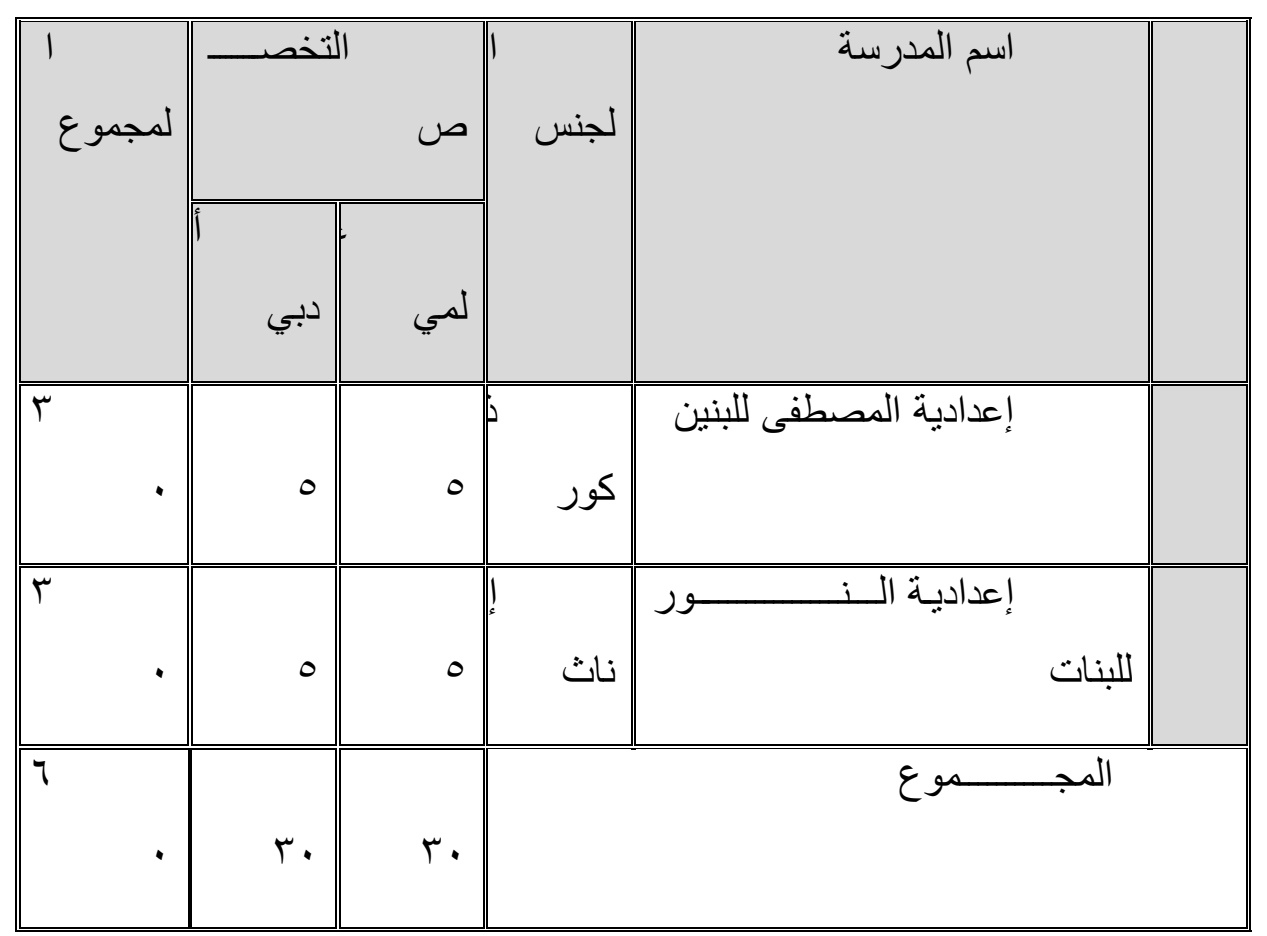

الإحصائي 
إن قياس تمييز كل فقرة يهدف إلى عملية استبعاد كل الفقرات التي لا تميز بين المستجيبين من هذه

الفقرات و الإبقاء على الفقرات التي تعمل على التمييز بينهم .

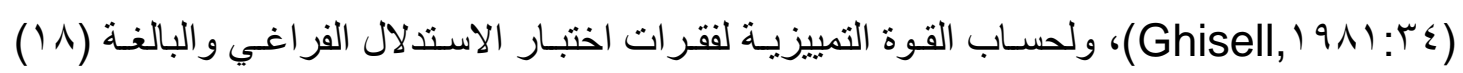

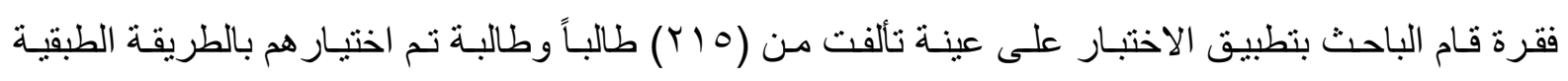

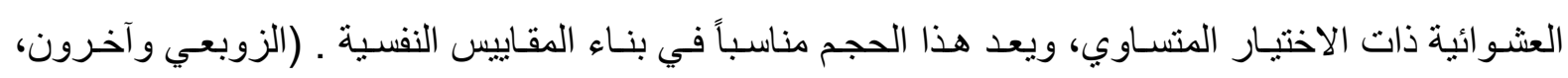

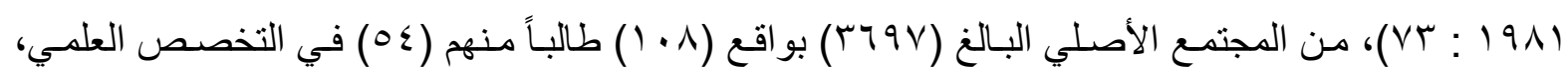

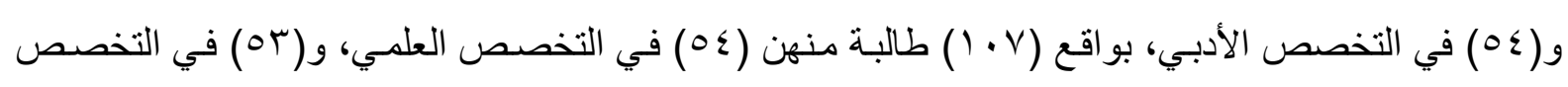
الأدبي تم توزيعهم على (T) مدارس إعداديـة للتخصص لعلمي، و(7) مدر اس إعداديـة للتخصص الأدبي، وقد تم استـخر اج القوة التمييزيـة لفقرات الاختبـار بطريقـة المجمـوعتين المتطـرفتين طريقـة (الاتسـاق الخـارجي) وطريقة (الاتساق الداخلي) وكما يأتي :

\section{أولاً : طريقة الجمسموعتين المتطرفتين (الاتسـاق المخارجي) .}

لأجل حساب تمييز فقرات الاختبار بهذه الطريقة اتبع الباحث الخطوات الآتية :

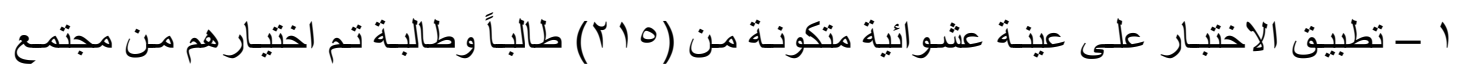

البحث موزعين على وفق متغيري الجنس و التخصص الدراسي .

r - تصحيح فقرات الاختبار الذي تكون من ستة مجالات هي (التدوير الرأسي، التدوير المحوري،

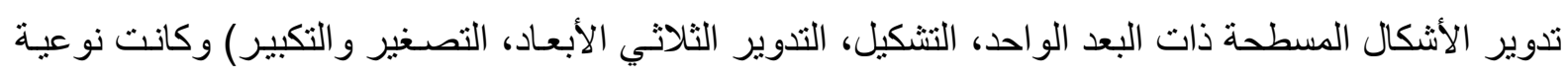
الفقر ات على صورة اختبار متعدد ذي ثنلاث بدائل، ويعد هذا النوع من الأسئلة الموضو عية الذي لا يتأثر تصحيحها بـالحكم الذاتي للمصحح، وقد سميت بالموضوعية من طريقة تصحيحها، بوصفها تخرج من رأي المصحح ويكون الجواب فيها محدداً ولا يختلف فيه اثنـان، إذ يكون التصحيح بإعطاء درجـة (واحد) للإجابـة الصحيحة عن كل فقرة من فقرات الاختبار، و إعطاء (صفر) عن كل إجابـة خاطئة أو متروكة، وهي الأوزان التي أشار بملائمتها ايبل في الاختبار ات النفسية .

(Ebel, $19 \vee r: \varepsilon r)$

r - جمع درجات كل مستجيب عن كل فقرة من فقرات الاختبار لا يجاد الدرجة الكلية عن كل فرد من أفر اد العينة .

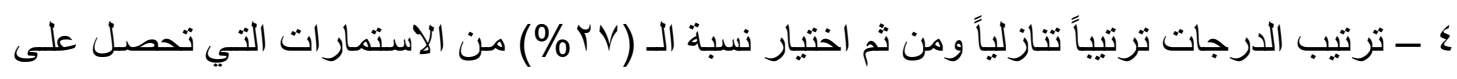

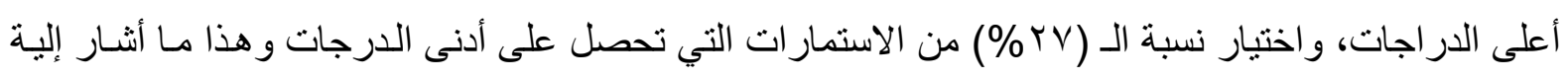

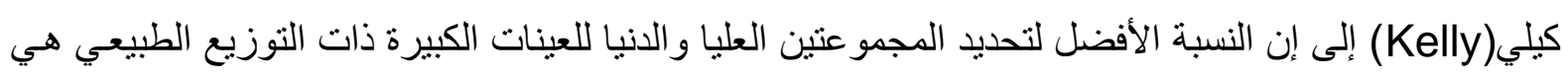

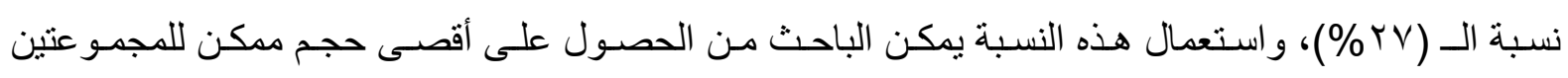

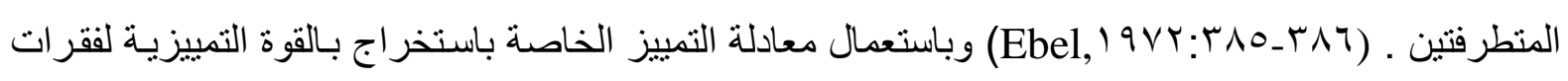

\section{$-M V \varepsilon$.}


اختبـار الاستدلال الفر اغي اتضـح إن فقرات الاختبـار كانت مميزة بدلالـة القيمـة الاحتماليـة . (p_vlue) كمـا

$$
\text { موضح في الجدول (0) }
$$

جدول(0) نتائج اختبار مربع كاي للتعرف على دلالة الفرق بين المجمو عتين العليا والدنيا في الاستدلال

الفر اغي لعينة التحليل الإحصائي

\begin{tabular}{|c|c|c|c|c|c|c|c|}
\hline \multirow{2}{*}{ الدلالة الد } & \multirow{2}{*}{ الاحتمالية } & \multirow{2}{*}{ مربع كاي } & \multicolumn{2}{|c|}{ المجموعة العليا } & \multicolumn{2}{|c|}{ المجموعة الدنيا } & \multirow{2}{*}{ الفقرات } \\
\hline & & & (واحد) & (صفر) & (واحد) & (صفر) & \\
\hline \multicolumn{8}{|c|}{ التذوير الرأسي } \\
\hline دالة & $\because \cdots$ & $\leqslant 7 . \leqslant \wedge 7$ & $\leqslant 7$ & Ir & 9 & $\varepsilon 9$ & 1 \\
\hline دالة & $\because \cdots$ & rq.V०0 & $\leqslant 0$ & 14 & IT & $\xi 7$ & $r$ \\
\hline دالة & $\because \cdots$ & $\varepsilon \wedge . \ldots q$ & or & 0 & 17 & $\varepsilon r$ & $r$ \\
\hline \multicolumn{8}{|c|}{ التدوير المحوري } \\
\hline دالة & $\because \cdots$ & YA.Y.r & 00 & $r$ & rq & rq & $\varepsilon$ \\
\hline دالة & $\cdots \cdots$ & rq.V & 00 & $\mu$ & $r r$ & ro & 0 \\
\hline دالة & $\because \cdots$ & $\varepsilon \neg . \& \wedge r$ & $0 \leqslant$ & $\varepsilon$ & 11 & $\varepsilon$. & 7 \\
\hline \multicolumn{8}{|c|}{ تدوير الأشكال المسطحة } \\
\hline دالة & $\because \cdots$ & $19 . M H Y$ & $r q$ & 19 & 10 & $\varepsilon r$ & $V$ \\
\hline دالة & $\because \cdots$ & YM.YHY & $\leqslant V$ & 11 & YI & $r v$ & $\wedge$ \\
\hline دالة & $\because \cdots$ & YV.IVV & $0 \leqslant$ & $\varepsilon$ & $r \wedge$ & $r$ & 9 \\
\hline \multicolumn{8}{|r|}{ التشكيل } \\
\hline دالة & $\because \cdots$ & $r \cdot . \varepsilon \leqslant V$ & $\varepsilon Y$ & 17 & Ir & $\varepsilon 7$ & 1. \\
\hline دالة & $\because \cdots$ & IV.Y.r & 01 & $\mathrm{~V}$ & $r$ & $r \wedge$ & 11 \\
\hline دالة & $\because \cdots$ & $r 9.99$ & 00 & $r$ & $r r$ & ro & Ir \\
\hline \multicolumn{8}{|c|}{ تدوير الأشكال ثلاثية الأبعاد } \\
\hline دالة & $\because \cdots$ & $1 Y .00 \mathrm{~V}$ & $0 \xi$ & $\varepsilon$ & $r \Lambda$ & $r \cdot$ & 14 \\
\hline دالة & $\because \cdots$ & IY.ME & rq & 19 & $r \cdot$ & $r \Lambda$ & $1 \leq$ \\
\hline دالة & $\because \cdots$ & IT.YYT & $\varepsilon$ & 11 & $r \cdot$ & $r \Lambda$ & 10 \\
\hline \multicolumn{8}{|c|}{ التصغير والتكبير } \\
\hline دالة & $\because \cdots$ & $1 \varepsilon . \wedge V V$ & $\leqslant 9$ & 9 & rq & rq & 17 \\
\hline دالة & $\because \cdot Y \Lambda$ & $\varepsilon . \wedge 1$ & $0 \leqslant$ & $\varepsilon$ & $\varepsilon 0$ & 14 & IV \\
\hline دالة & $\because \cdots$ & $r . . r q q$ & 01 & $\cdot$ & $\varepsilon$ & 11 & 11 \\
\hline
\end{tabular}

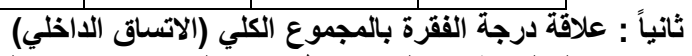

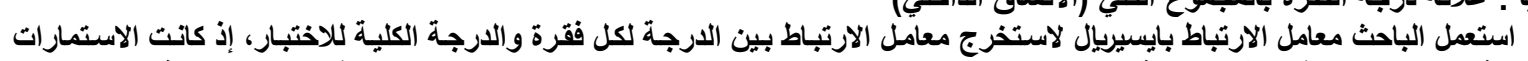

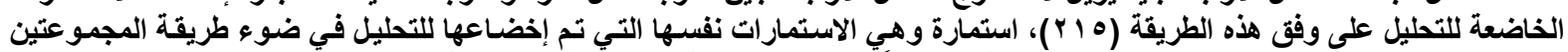

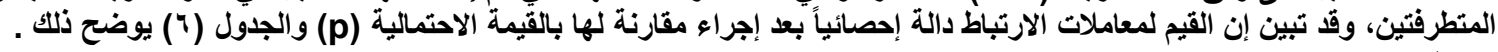

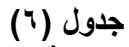
نتائج قياس العلاقة الارتباطية بين درجة الفقرة ومجموع درجات المجال والمجموع الكلي لاختبار الاستدلال الفراغي

\begin{tabular}{|c|c|c|c|c|c|c|}
\hline الدلالة & الاحتمالية & الكلي & الدلالة & الاحتمالية & مجال التدوير الرأسي & الفقرة \\
\hline دالة & $\because \cdots$ & $\because \leqslant 9 V$ & دالة & $\because \cdots$ & $\because \vee \wedge \neg$ & 1 \\
\hline دالة & $\because \cdots$ & $\because \leqslant Y r$ & دالة & $\because \cdots$ & .701 & $r$ \\
\hline دالة & $\because \cdots$ & $\because \leqslant \vee 7$ & دالة & $\because \cdots$ & $\because V \otimes \Lambda$ & $r$ \\
\hline الدلالة & الاحتمالية & الكلي & الدلالة & الاحتمالية & مجال التدوير المحوري & \\
\hline دالة & $\because \cdots$ & $\because \leqslant Y 1$ & دالة & $\because \cdots$ & .74 & $\varepsilon$ \\
\hline دالة & $\because \cdots$ & $\cdot . \wedge \leqslant$ & دالة & $\because \cdots$ &. .117 & 0 \\
\hline دالة & $\because \cdots$ & .017 & دالة & $\because \cdots$ & $\because \vee \wedge 0$ & 7 \\
\hline الدلالة & الاحتمالية & الكلي & الدلالة & الاحتمالية & 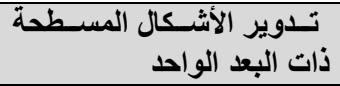 & \\
\hline دالة & $\because \cdots$ & $\cdot r \leqslant 0$ & دالة & $\because \cdots$ & $\because .7 \wedge \wedge$ & v \\
\hline دالة & $\because \cdots$ & $\because r \wedge \theta$ & دالة & $\because \cdots$ & .900 & $\wedge$ \\
\hline
\end{tabular}




\begin{tabular}{|c|c|c|c|c|c|c|}
\hline لة & $\because \cdots$ & $\cdot r q$. & & $\because \cdots$ & $\cdot .799$ & 9 \\
\hline الالالة & الاحتمالية & الكلي المجـــــوع & الدلالة & الاحتمالية & مجال التشكيل & \\
\hline لة & $\because \cdots$ & $\because r \wedge \wedge$ & & $\because \cdots$ & $\because .717$ & 1. \\
\hline لة & $\because \cdots$ & 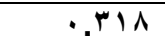 & & $\because \cdots$ & . & 11 \\
\hline لة & $\because \cdots$ & .OYT & & $\because \cdots$ & $9.7 \times 9$ & Ir \\
\hline الالالة & قاحتمالية & الكلي المجــــــوع & الدلالة الدالة & الاحتمالية & مجال التدوير ثلاثي الأبعاد & \\
\hline لة & $\because \cdots$ & $\cdot r \cdot r$ & & $\because \cdots$ & $\cdot r q$. & ir \\
\hline لة & $\because .10$ & $\because 1 \leq \leqslant$ & & $\because \cdots$ & $\cdot .7 \cdot 1$ & $1 \varepsilon$ \\
\hline لة & $\because \cdots$ & $. Y q \leq$ & & $\because \cdots$ &. $.7 \vee 9$ & 10 \\
\hline الالالة & الاحتمالية & الكلى المجمــــوع & الدلالة & الأيتمالية & مجال التصغير والتكبير & \\
\hline لة & $\because \cdots$ & $\because r r V$ & & $\because \cdots$ &. .710 & 17 \\
\hline لة & $\because \cdots v$ & $\because 1 \wedge \varepsilon$ & & $\because \cdots$ & $\cdot .7 \cdot V$ & iv \\
\hline لة & $\because \cdots$ & ?rYA & & $\because \cdots$ & .017 & 11 \\
\hline
\end{tabular}

جدول (V) مصفوفة العلاقات الارتباطية بين مجموع درجات المجال والدرجة الكلية للاختبار

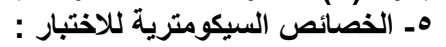

\begin{tabular}{|c|c|c|c|c|c|c|c|}
\hline الكلي المجـوع & والتكبير & 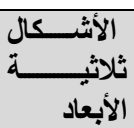 & التشكيل & المسطحة الأشــكال & المحوري التــــوير & المؤشرات & المجال \\
\hline$\cdot .7 \leqslant$ &. $.0 Y$ &. .107 & $\cdot . r \mid r$ & $\cdot r \leqslant 1$ & $\cdot .517$ & معامل الارتباط & \multirow{3}{*}{ التدوير الرأسي } \\
\hline$\therefore \cdots$ & $\therefore \leqslant \leqslant \wedge$ & $\because$ YY & $\because \cdots r$ & $\because \cdots$ & $\therefore \cdots$ & قيمة p الاحتمالية & \\
\hline دالة & غير دالة & دالة & دالة & دالة & دالة & الدلالة & \\
\hline. .701 & $\cdot r \mid r$ & $\because \leqslant 1$ & $\cdot r \leqslant Y$ & $\because$ YOr & & معامل الارتباط & \multirow{3}{*}{ 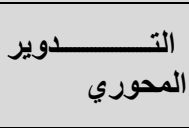 } \\
\hline$\ldots$ & $\ldots \cdots$ & .00 & $\because \cdots$ & $\because \cdots$ & & قيمة p الاحتمالية & \\
\hline دالة & دالة & غير دالة & دالة & دالة & & الدلالة & \\
\hline .009 & $\because .1 \leqslant V$ & $\because \vee \vee \wedge$ & $\cdot .110$ & & & معامل الارتباط & \multirow{3}{*}{ تـدوير الأثـكال } \\
\hline$\ldots$ &..+1 &. .771 & $\because \cdots V$ & & & قيمة p الاحتمالية & \\
\hline دالة & دالة & غير دالة & دالة & & & الدلالة & \\
\hline. $.7 r r$ &. .17 & . rrq & & & & معامل الارتباط & \multirow{3}{*}{ التشكيل } \\
\hline$\because \cdots$ & $\because \cdots$ & $\because .17$ & & & & قيمة p الاحتمالية & \\
\hline دالة & دالة & دالة & & & & الدلالة & \\
\hline. $.49 \Lambda$ & $\because .87$ & & & & & معامل الارتباط & \multirow{3}{*}{ ثلاثية الأبعاد الأشـكال } \\
\hline$\ldots \cdots$ &. .91 & & & & & قيمة p الاحتمالية & \\
\hline دالة & غير دالة & & & & & الالالة & \\
\hline$\therefore \leqslant 9$. & & & & & & معامل الارتباط & \multirow{3}{*}{ والتكبير } \\
\hline$\therefore \cdots$ & & & & & & قيمة p الاحتمالية & \\
\hline دالة & & & & & & الالالة & \\
\hline
\end{tabular}

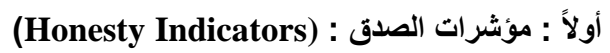

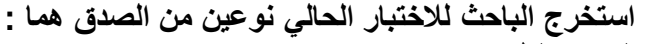

أ - الصدق الظاهري (Face Validity)

للتحقق من مدى صلاحية فقر ات الاختبار قام الباحث بعرض فقرات الاختبار على مجموعة من

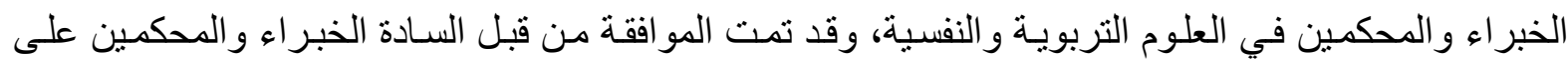
جميع فقرات الاختبار . 
ب - صدق البناء (instruct Validity)

اعتمد الباحث لقيـاس صـدق البنـاء على طـريقتين همـا القوة التمييزيـة باستعمال أسلوب العينتين

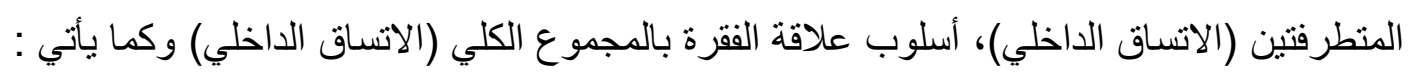

- أسلوب العينتين المتطرفتين (الاتسـاق الحنارجي)

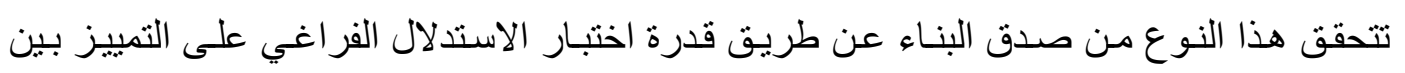

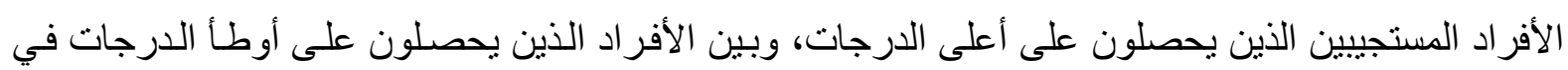

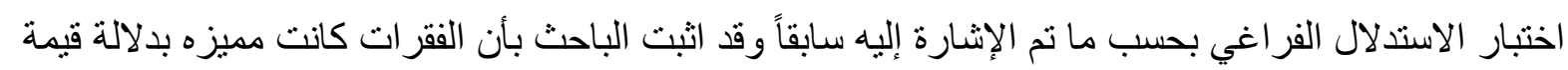
الاحتمالية . (p)

\section{- أسـلوب علاقة الفقرة بالجموع الكسلي (الاتسـاق الداخلسي)}

يتحقق هذا النوع من صدق البناء من خلال إيجاد العلاقة الارتباطية بين درجات كل فقرة و الدرجة

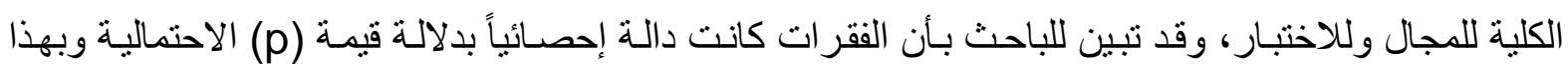
تحقق الباحث من مؤشرات صدق اختبار الاستدلال الفراغي .

(Stability Indicators) : ثانياً : مؤشرات الثبات

تم حساب ثبات الاختبار الحالي بطريقتين هما :

أ إعادة الاخختبسار (The test Reestablishment)

لحسـاب معامل الثبـات على وفق هذه الطريقة تم تطبيق الاختبـار على عينـة بلغت ( •ـ) طالبـاً

وطالبة من المدارس الإعدادية في مركز مدينـة الكوت، وبعد إجراء التطبيق الأول للاختبـار تم إعادة التطبيق مرة أخرى على الطلبة أنفسهم وبعد مرور أسبو عين، وباستعمال معامل الارتباط بيرسون بين درجات الطلبة

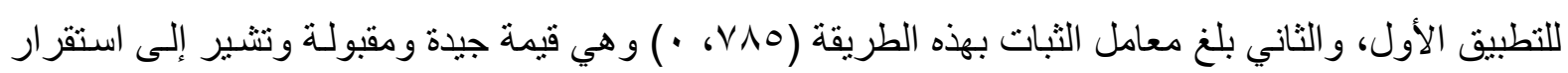
إجابات الطلبة على الاختبار عبر الزمن .

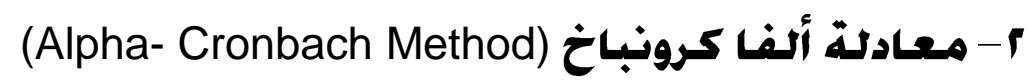
قام الباحث باستخر اج ثبات اختبار الاستدلال الفراغي باستعمال معادلة الفا كرونباخ حيث بلغ الفيات

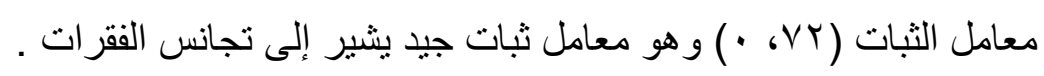

$$
\text { (عبسوي، } 1910 \text { : (ع) }
$$

\section{1 - الخصسائص الإحصسائية الوصفية للاختبار :}

نم الحصول على التقديرات الإحصائية الوصفية لدرجات أفر اد عينة الاختبار والجدول (^)يوضح ذلك اللك 
جدول (^) الخصائص الوصفية الإحصائية لاختبار الاستلال الفراغي لعينة التحليل الإحصائي

\begin{tabular}{|c|c|c|}
\hline الخطأ المعياري & الإحصاءات & الخصائص \\
\hline \multirow[t]{9}{*}{ 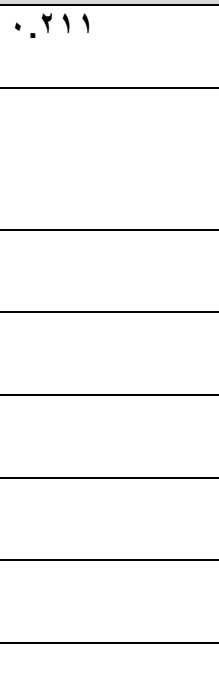 } & $11 . \varepsilon r$ & المتوسط الحسابي \\
\hline & $11 . \$ 1$ & الوســط الحسـابي \\
\hline & & المشذب \\
\hline & IY... & الوسيط \\
\hline & $9.04 \xi$ & التباين \\
\hline & $r . \cdot \wedge \wedge$ & الاتحراف المعياري \\
\hline & $r$ & أدنى درجة \\
\hline & 11 & أعلى درجة \\
\hline & 10 & المدى \\
\hline. .174 & C.r. & الالتواء \\
\hline ..$r \mu$. & $\because \varepsilon \wedge \cdot-$ & التفلطح \\
\hline
\end{tabular}

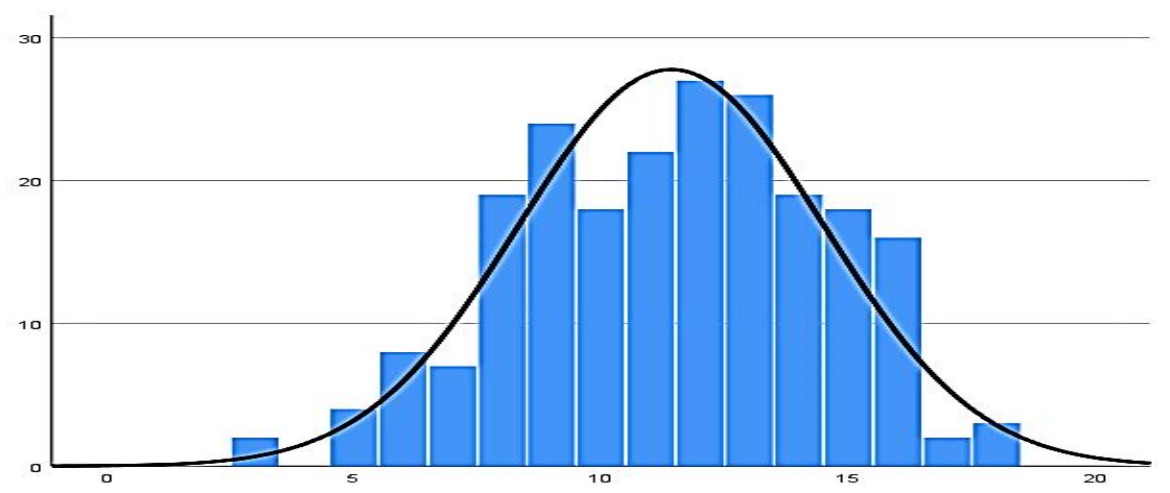

شكل ( ') توزيع درجات أفر اد عينة التحليل الإحصائي في الاستدلال الفر اغي وفقاً لمحور التوزيع الطبيعي الصيغة النهائية لاختبار الاستدلال الفراغي :

بعد الانتهاء من أجر اء المعالجات الإحصائية من تحليل فقرات الاختبار وإيجاد الخصائص السيكومترية من (صدق وثبات) بقي عدد فقرات الاختبار (1) ) فقرة موزعة على ستة مجالات

التطبيـق النهـائي للاختبـار : بعـد إجـر اء التحليـل الإحصـائي واسـتخر اج الخصـائص السـيكومنرية و الوصـفية لاختبـار الاستدلال الفراغي، قـام الباحث بتطبيق اختبـار الاستدلال الفراغي على عينـة التطبيق البـالغ عددها

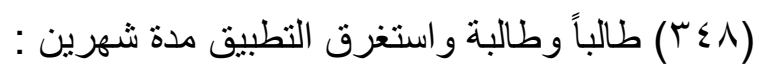

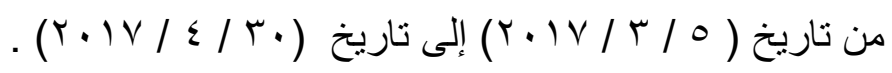


الوسبائل الإحصسائية : (Statistical Means)

استعان الباحث بالحقيبة الإحصائية للعلوم الاجتماعية (spss) في تحليل البيانات، وقد استعمل

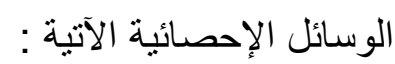

1 ـ الاختبار التائي لعينتين مستقلتين : وقد استعمل للتعرف لحساب القوة التمييزية لفقرات اختبار الاستدلال الفر اغي .

r - الاختبار التائي لعينة واحدة : وقد استعمل للتعرف على اختبار الاستدلال الفر اغي لدى عينة البحث . r - معامل الارتباط بيرسون : وقد استعمل لاختبار الاستنلال الفراغي، واستخر اج صدق البناء، وأيضـا

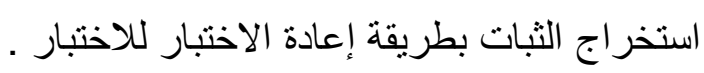
ع- معادلة الفا كرونباخ للاتساق الداخلي : وقد استعمل لحساب ثبات اختبار الاستدلال الفراغي . 0ـ تحليل التباين الأحسادي بتفاعل : وقد استعمل لا يجـاد الفروق بحسب الجنس و التخصص في اختبار

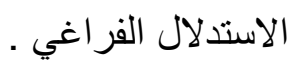

1 - مربع كاي : وقد استعمل لحساب القوة التمبيزية لفقرات اختبار الاستدلال الفراغي بأسلوب المجمو عتين

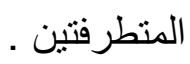

V - مجموعة معادلات المقاييس الوصفية : (الوسط الحسابي، الوسط الحسابي المشذب، الوسيط، التباين،

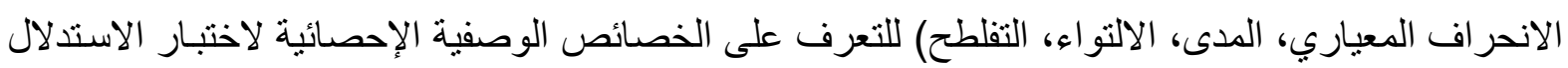
الفر اغي. ^ - مربع ايتا الجزئي لحساب الأثر .

\section{(الفصسل الخامس)}

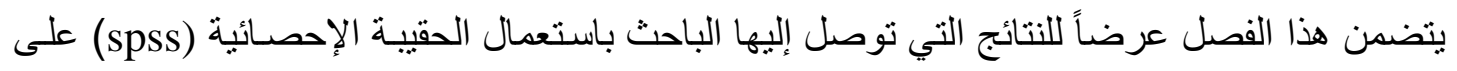

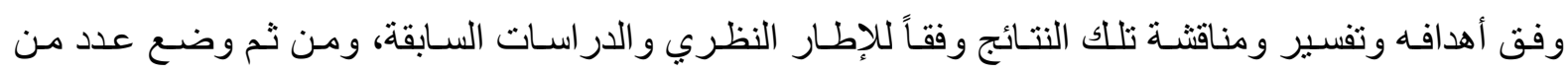
التوصيات و المقترحات في ضوء النتائج و على النحو الآتي :

\section{الأول : تعـرف الاستدلال الفراغي لدى طلبة الصـف الخامس الإعدادي .}

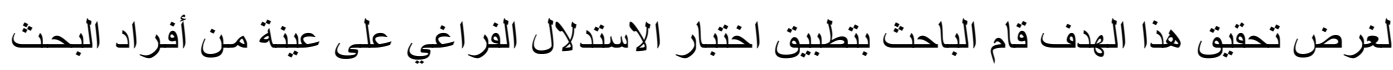

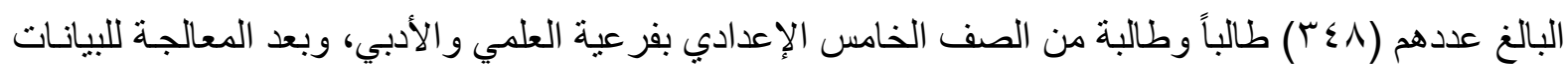

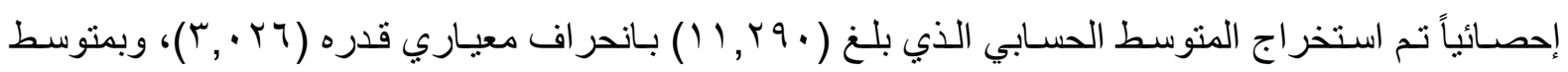

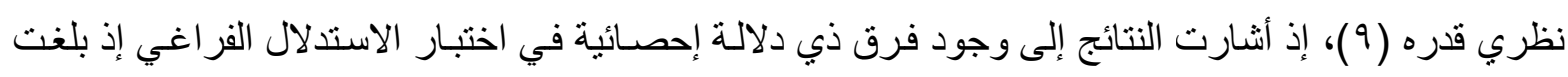

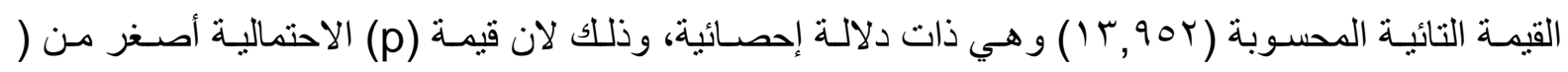

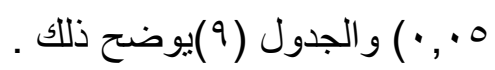


جدول (9) نتائج الاختبار التائي لعينة واحدة للتعرف على دلالة الفرق في الاستدلال الفراغي

\begin{tabular}{|c|c|c|c|c|c|c|c|}
\hline اللالالة & 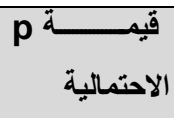 & التائية & المعياريـا المتوســـ & النظري المتوســــ & الانعـــــاف & المسابي المتوســــ & المتغير \\
\hline دالة & $\cdots$ & $1 \% .904$ & \& & 9 & $r . r^{T}$ & 11.89. & الاستـلا \\
\hline
\end{tabular}

ويتضح من الجدول (9) إن الفرق دال إحصائياً ولصالح المتوسط الحسابي وهذا يشير إلى إن طلبة

المرحلة الإعدادية يمتلكون القدرة على الاستدلال الفراغي

ويمكن إرجاع هذه النتيجـة أيضـاً إلى قدرة الطلبـة على تخيل الإبعـاد للإشـكال الهندسية، و العمليـات

الإدر اكية وذلك نتيجة التطور الحاصل في مجـال التكنولوجيـا للعصر الحسالي، ونتيجـة ظهور وسـائل الاتصـال الحديثة من أجهزة الموبايل والايباد وظهور الثبكة العنكبوتية (الانترنيت) وغير هاوما تحتويه هذه الوسـائل من العـاب الكترونيـة كالعـاب المتاهـات والألعـاب ثلاثيـة الأبعاد، و الرسوم و المخططـات الهندسية، وبـر امج تحديد ولهيد

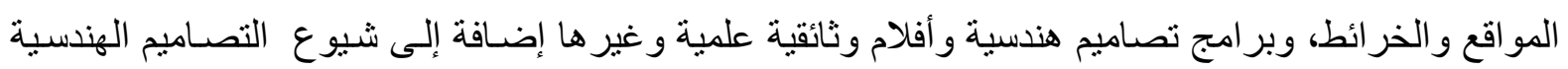
ثلاثية الأبعاد والديكور ات وما يتطلبه من عملية دوران ولفت وتحويل للأشكال والنمـاذج الهندسية الأمر الذي وني كان له انعكاس واضح ومؤثر في نمو القدرات الفر اغية، ومنها الاستدلال الفر اغي لدى الطلبة . ثانياً : تعرف دلالـة الفروق في الاستدلال الفر اغي تبعاً لمتغيري الجنس (ذكور، إنـاث) و التخصص (علي، أدبي)

لتعرف دلالة الفروق في الاستدلال الفر اغي تبعاً لمتغيري (الجنس، والتخصص) استعمل الباحث تحليل التبـاين بتفاعل، وسـيقوم الباحث بعرض المؤشـرات الإحصـائية لاختبـار الاســلال الفر اغـي و الجدول ( • (1) يوضح ذلك.

جدول (· () الخصائص الوصفية لعينة التطبيق النهائي في الاستلال الفراغي

\begin{tabular}{|c|c|c|c|c|c|}
\hline المئوية & العينة & 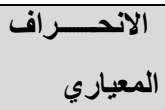 & 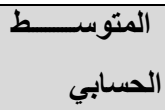 & التخصص & الجنس \\
\hline$\%$ \% & $1 Y \varepsilon$ & 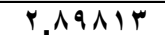 & IY.TVVE & العلمي & \multirow{3}{*}{ ذكر } \\
\hline$\% 17$ & 07 & $r . \Delta \wedge V \leq r$ & $1 . .7 \vee \wedge 4$ & الأدبي & \\
\hline$\% \circ r$ & $1 \wedge$. & 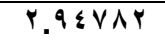 & 19.004 & المجموع & \\
\hline$\% r r$ & 117 & $r . \wedge \leq M 17$ & $11 . r \wedge \leqslant 0$ & العلمي & \multirow{3}{*}{ نثى } \\
\hline$\% 10$ & Or & r.SYYO. & $\Lambda .70 \% \wedge$ & الأدبي & \\
\hline$\% \leqslant \wedge$ & 171 & 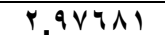 & $T \cdot . \varepsilon V \cdot Y$ & المجموع & \\
\hline
\end{tabular}




\begin{tabular}{|c|c|c|c|c|c|}
\hline$\% 79$ & $r \leq$. & $r . q \leq q r q$ & Ir... & العلمي & \\
\hline$\%{ }^{\prime \prime}$ & 1.1 & Y.V...人o & $q . V \cdot r v$ & الأدبي & المجموع \\
\hline$\% 1 \ldots$ & $r \leqslant \Lambda$ & $r . \cdot 7 r \mid r$ & 11.89 .4 & المجموع & \\
\hline
\end{tabular}

وللتعرف على دلالة الفرق بين متغيري البحث في الاستدلال الفر اغي استعمل الباحث تحليل التباين بتفاعل و الجدول ('l') يوضح ذلك .

جدول (1') نتائج اختبار تحليل التباين بتفاعل للتعرف على دلالة الفرق في الاستدلال الفر اغي تبعاً لمتغيري الجنس (ذكور/ إناث) و التخصص (علمي/ أدبي) لعينة التطبيق النهائي

\begin{tabular}{|c|c|c|c|c|c|c|c|}
\hline الجزئي ايتـا & الدلالة & الاحتمالية & القائية & 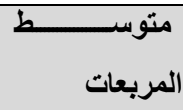 & الدرية درجـــات & مجموع المربعات & مصدر التباين \\
\hline$\because \cdot \sqrt{ }$ & دالة & $\because \cdots$ & $r \wedge . r \wedge r$ & YIV.YIV & 1 & YIV.rIV & الجنس الإنساني \\
\hline \multirow[t]{4}{*}{. .141} & دالة & $\because \cdots$ & Or. VA & P१^.07 & 1 & К9^.077 & التخصص العلمي \\
\hline & غالة غيـــر & . rYo & $.9 V$. & $V . \& Y r$ & 1 & $V . \& Y Y$ & التخصص*|لجنس \\
\hline & & & & $V .70 \mathrm{r}$ & $r \leqslant \varepsilon$ & r7rr.79r & الخطأ \\
\hline & & & & & $r \leqslant \Lambda$ & \&VTIT.... & المجموع \\
\hline
\end{tabular}

$$
\text { وتثنير النتائج إلى ما يأتي : }
$$

\section{- 1}

أظهرت النتائج انـه يوجد فرق ذبي دلالة إحصـائية في الاستدلال الفر اغي تبعاً لمتغير الجنس ولصـالح

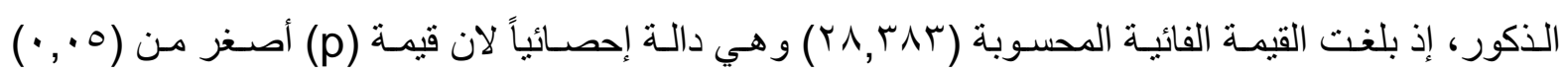

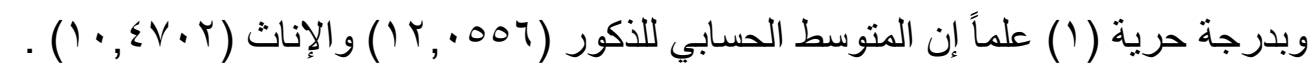

أظهرت النتائج انـه يوجد فرق ذي دلالـه إحصـائية في اختبـار الاستـلال الفر اغـي تبعـاً لمتغيـر

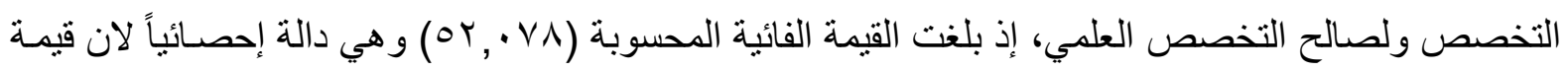

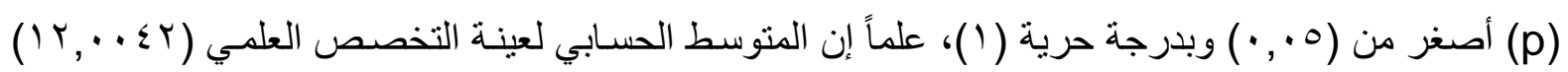

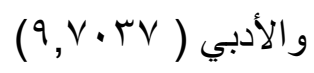

\section{س- التفاعل بين (التخخصم، الجسنس)}


أظهرت النتائج انه لا يوجد تفاعل في اختبار الاستدلال الفراغي تبعاً لمتغير التخصص،

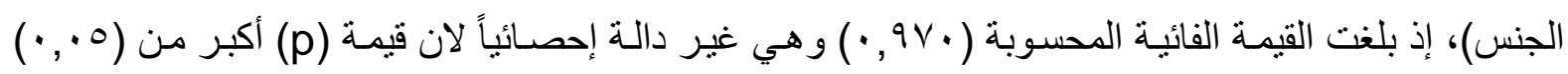

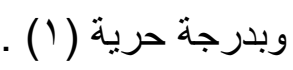

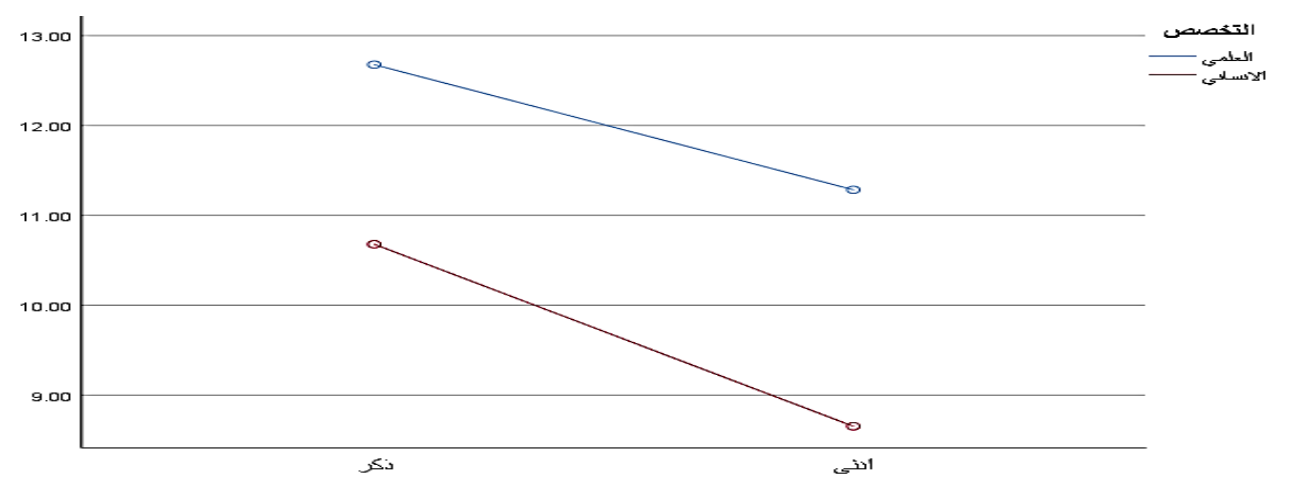

شكل (r) التمثيل البياني لارجات أفراد عينة التطبيق النهائي في الاستدلال الفراغي تبعاً لمتغيري الجنس الإنساني والتخصص ويتضح من الجدول(' 1' ) ما يأتي :

يوجد فرق ذي دلالة إحصائية في متغير الجنس (ذكور، إناث) ولصالح الذكور ويمكن إرجاع ذلك

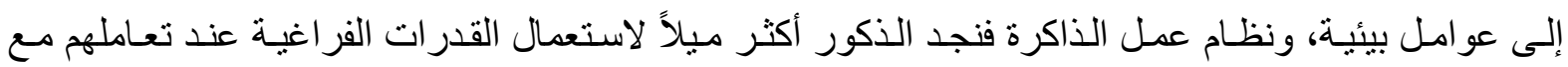
مفردات البيئة لذا فهم أكثر حرية وانفتاحاً في الحركة والانتقال من الإناث، لذا تعد الحركة والانتقال في البيئة من المصادر المهمة لتعلم المهار ات الفراغية، كما قد يعود ذلك إلى الفرق في الاستر اتيجيات المعرفيـة المتبعـة بين الجنسين فنجد الذكور يستعملون استر اتيجيات حل المشكلات، واهم أكثر في التعامل مـع المهــات الفر اغيـة

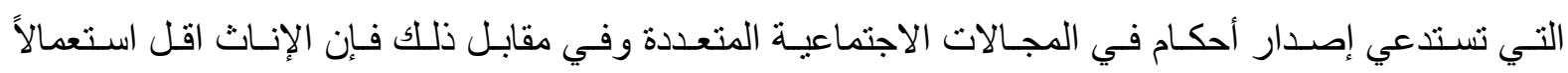
لاستر اتيجيات حل المشكلات الفراغية ويتجهن نحو تبني البنية المعرفية في المو اقف الاجتماعية . كما إن الإناث في الغالب يفضلن استعمال استراتيجيه التحليل الذي يتضمن تجزئة الثكل الذي يعد بمثابة المثير إلى أجز اء ثم إجر اء مقارنته ضمن عمليات متتابعة ومن ثم التأكد من تطابق الملامـح الخاصـة بالثكل المعطى مع الثكل الأساسي أمـا الذكور فيفضلون الإستر اتيجية الكلية، إذ إنهم يتخيلون الثكل بصورة كاملة ثم يقومون بتدويرات وتمثيلات كلية للأشكال في عقولهم .، كما إن الذكور يتفوقون في المهمات التي تتطلب إدر الك فر اغي، في حين تتفوق الإناث في المهمات اللفظية . وقد يعود ذلك إلى أبعاد بايلوجية فالذكور يتعاملون مع الأشكال الهندسية المدورة ذات الاستعمالات المتعددة للكثير من الأعمال التي يمارسونها فيبدون أكثر قوة واندماجاً في المهمـات الفراغية لتنفيذ مهمـاتهم العملية بالدرجة القصوى من الفاعلية، وقد أثـار (Annet, 1910) إلى إن دمـاغ الذكور و لاسيما نصفه الأيمن من الدماغ مكيف ومكرس بصورة دقيقة للعمليات الفر اغية بشكل كامل، إذ إن الذكور عادة يميلون إلى استعمال

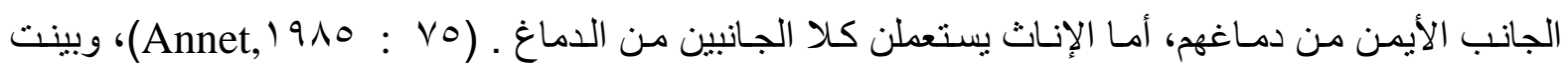

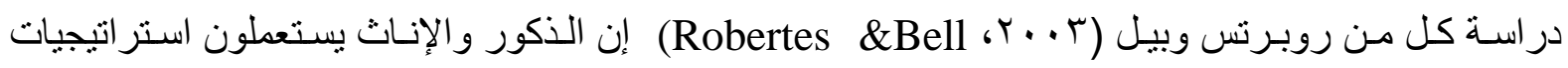


عصبية مختلفة لحدوث الاستدلال الفراغي فضلاً عن إن الذكور يؤدون أفضل من الإنـاث في المهمات الثنائية

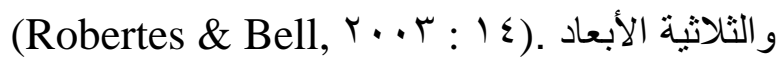

وتثير الدراسات التي أجريت على القدرة الفر اغية إلى اتساق الفروق الفردية المرتبطـة بهذه القدرة من

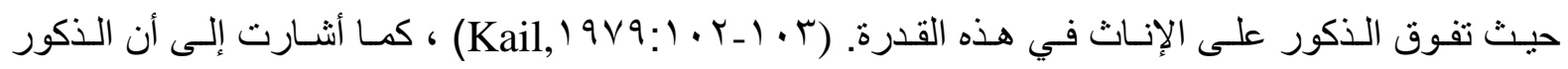
يتفوقون في المقاييس الفر اغية والعدديـة والميكانيكيـة لاختبـار ات الذكاء، في حين تمتاز الإنـاث في الاختبار ات

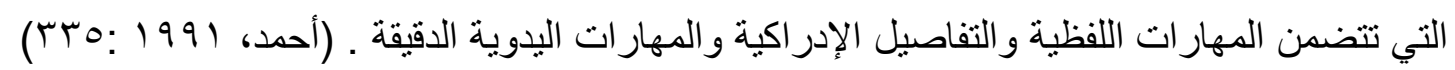
كما أشتارت النتائج إلى وجود فرق ذي دلالة إحصـائية تبعاً لمتغير التخصص (علمي، أدبي) ولصسالح التخصص العلمي، ويمكن إرجاع ذلك إلى إن طلبة التخصص العلمي لديهم القدرة على التعامل مـع المجسمات والأشكال الهندسية التي تعزز لليهم مهارة المعالجة لهذه الأشكال وتدوير ها وتحويلها في بعد واحد أو بعدين أو أو لهات ثلاثة أبعاد أكثر من التخصص الأدبي .

كما يرجع ذلك إلى طبيعة المفردات للموضو عات التعليمية التي يتضمنها التخصص العلمي كالهندسـة و الرياضـيات و الكيميـاء و الفيزيـاء التـي تعمل وتسـاعد على تشجيع وتتميـة القدرات الفر اغيـة ومنهـا الاستدلال الفر اغي بشكل أفضل مما لاى التخصص الأدبي ولئي

الأمر الذي جعلهم يتصفون بالدقة والسرعة في تخيل أبعاد الأشكال، والعمليات الإدر اكية الفراغية التي تحدث لذا أخذت هذه القدر ات تتطور تدريجياً حتى أصبحوا يتمتعون بالقدرة على الاستدلال الفر اغي تفوق طلبة قدرة التخصص الأدبي .

\section{الاستنتاجـات : (Conclusions)}

في ضوء نتائج الدراسة التي توصل إليها الباحث يمكن استنتاج ما يأتي : ا - يمثلك طلبة المرحلة الإعدادية القدرة على الاستدلال الفراغي .

r - يوجد فروق في الاستدلال الفر اغي تبعـاً لمتغير الجنس (ذكور، إنـاث) ولصـالح الطلبة الذكور، ويوجد فرق تبعاً لمتغير التخصص (علي، أدبي) ولصالح طلبة للتخصص العلمي .

(Recommendations) : التوصسيات

في ضوء نتائج الدراسة التي توصل إليها الباحث تم الخروج بالتوصيات الآتية :

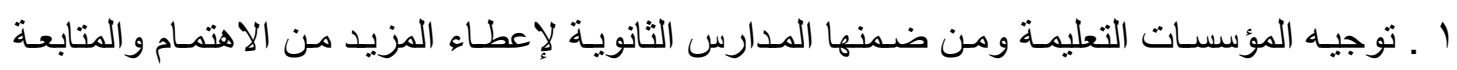

للطلبة وتشجيعهم على تنمية الاستدلال الفر اغي، وبذل المزيد من الجهود لتدريب الطلبة عليها .

r ـ الاستفادة من اختبار الاستدلال الفر اغي في تتخيص مستوى الاستدلال الفر اغي لدى الطلاب

ץ ـ تو عيـة التدريسيين بأهمية الاستـلال الفر اغي وتطوير هذه القدرة لديهم من خـلال إقامـة الندوات

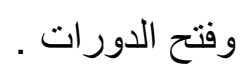




\section{(Suggestions) : المقترحات}

استكمالاً للجو انب المتعلقة بهذه الدراسة اقترح الباحث إجر اء دراسات لاحقة :

1 ـ إجر اء دراسات مشابهة على مر احل دراسية مختلفة، ومقارنة نتائجها مع نتائج الدر اسة الحالية .

ץ ـ ـ إجـر اء در اسـات تشــل مر احلـ تعليمـة عـدة (المتوسـطة، الإعداديـة، الجامعـة) لقيـاس الاسـتـلال

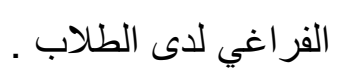

ب. ـ إجراء در اسـات تطوريـة لمتغير الاستـلال الفر اغي للتعرف على مدى تطور التفكير الرياضـي والاستدلال الفر اغي عبر مر احل تعليمية عدة ( المتوسطة، الإعدادية ، الجامعة) . ع . ـ إجراء در اسة ارتباطية في القدرة على الاستدلال الفراغي مع متغيرات أخرى (السر عة الإدر اكية،

التفكير المتشعب، أساليب التنشئة الاجتماعية) .

ه ـ إجر اء در اسة تتناول القيام بإعداد برنامج تدريبي لمدرسي الرياضيات تقوم على استر اتيجيات تنمي

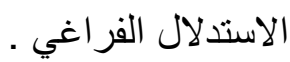

المصسادر العربيـة :

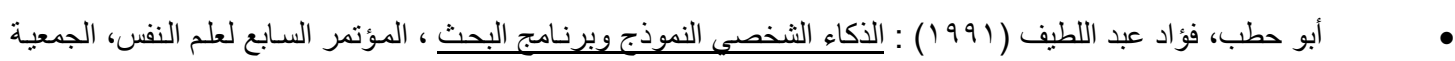

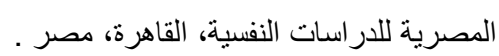

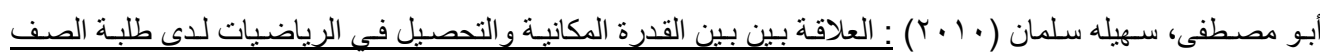

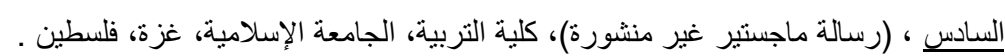

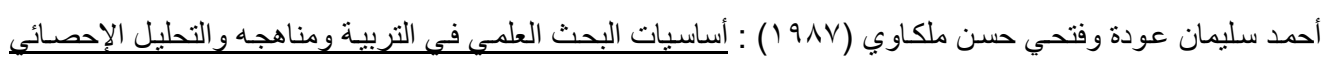

ليياناته ، مكتبة المنار للنثر والتوزيع، عمان، الأردن .

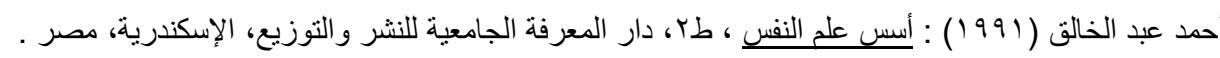

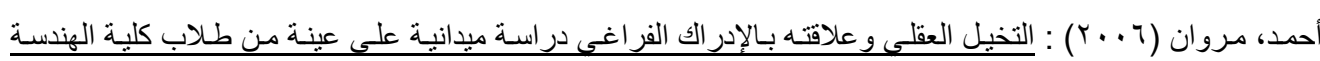

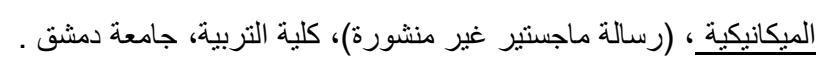

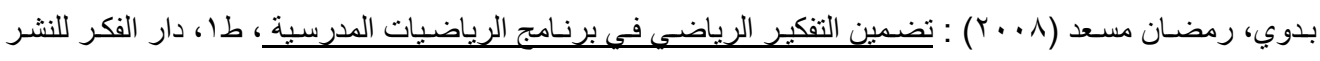

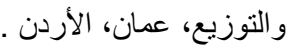

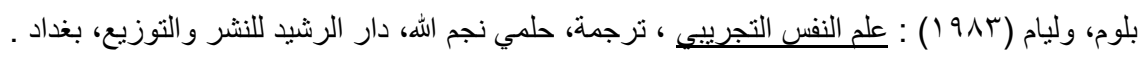

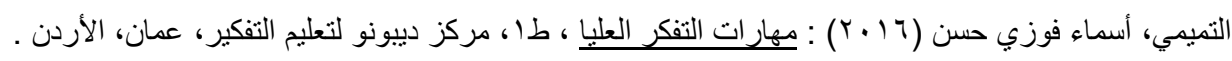

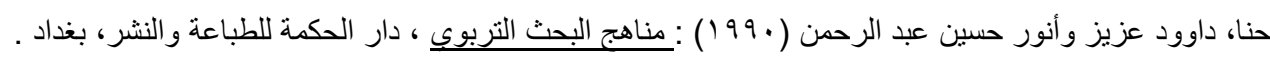

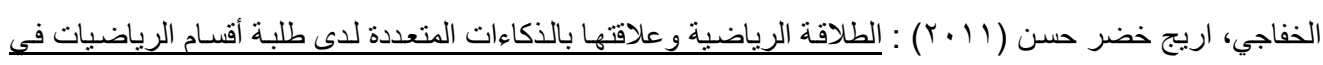

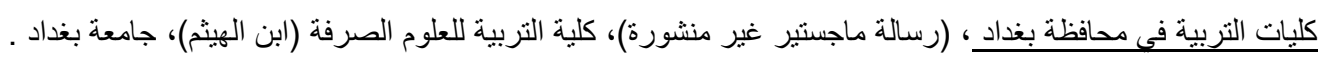

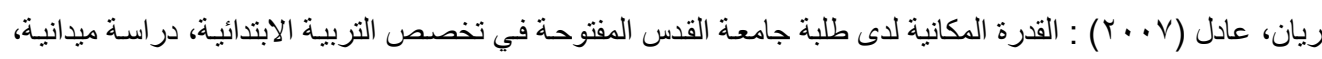

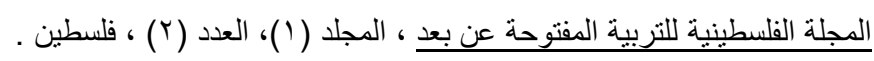

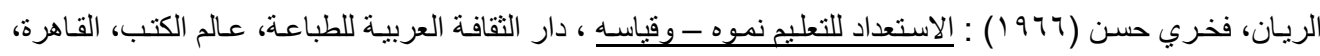

زيدان، محم مصطفى ونييل السمالوطي ( •99 ) : علع النفس التربوي، دار الثروق للنشر و التوزيع والطباعة، جدة، 


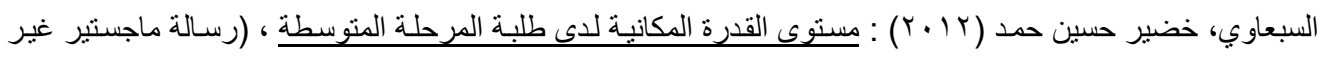

منشورة)، كلية التربية، جامعة الموصل .

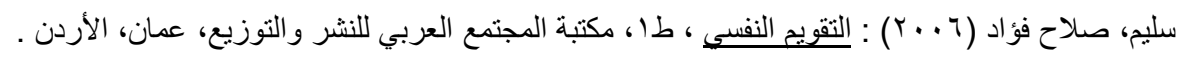

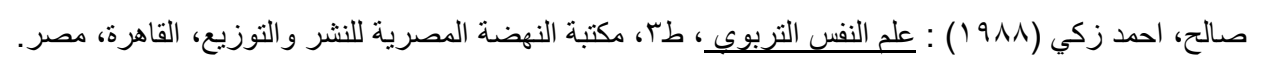

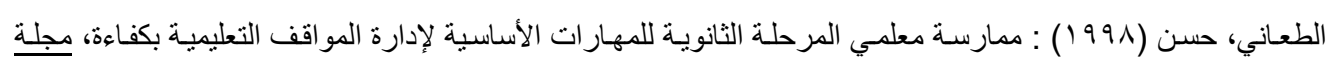

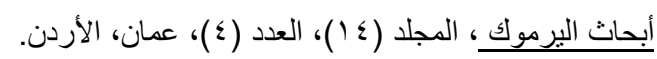

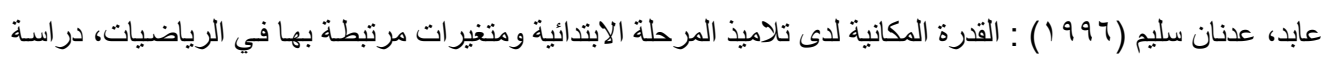

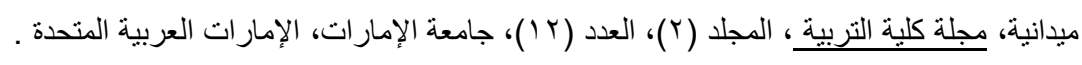

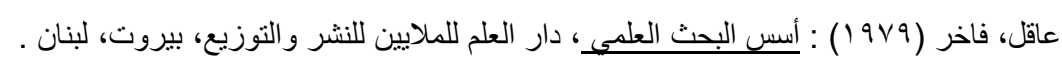

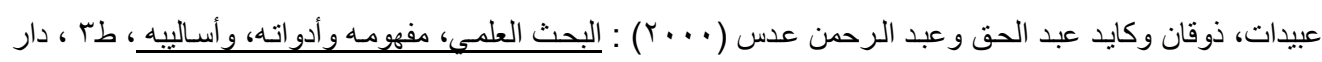

أسامة للنشر و التوزيع، الرياض، السعودية .

عودة، أحمد سليمان وخليل يوسف الخليلي (911 (1) : الإحصاء للباحث في التربيـة والعلوم الإنسانية ، دار الفكر للتوزيع والنشر، عمان، الأردن .

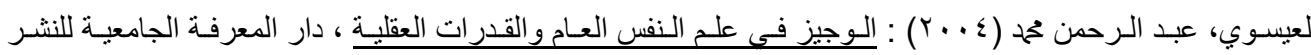

و التوزيع، بيروت، لبنان .

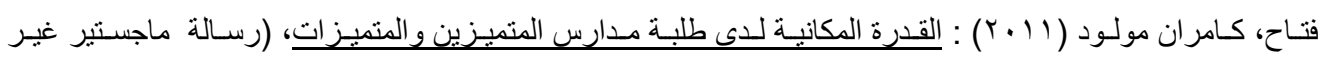

منشورة)، كلية التربية (ابن الهيثم)، جامعة بغداد .

فرج، صفوت ( • (191) : علع النفس و القياس النفسي ، مكتبة مدبولي للنشر،القاهرة .

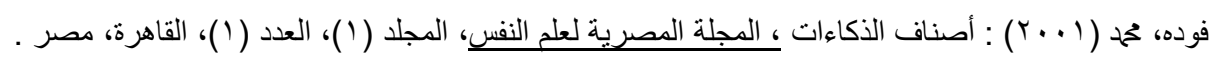

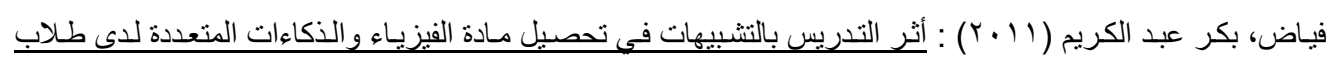

الصف الخامس العلمى ، (رسالة ماجستير غير منشورة)، كلية التربية للعلوم الصرفة (ابن الهيثم)، جامعة بغداد .

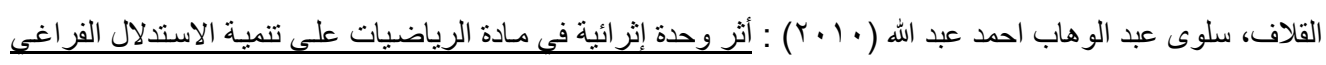

و تحسن التحصيل في الهندسة لدى تلميذات الصف الخـامس الابتدائي، (رسـالة ماجستير غير منشورة)، كلية الدراسـات العليا، جامعة الخليج العربي، الكويت .

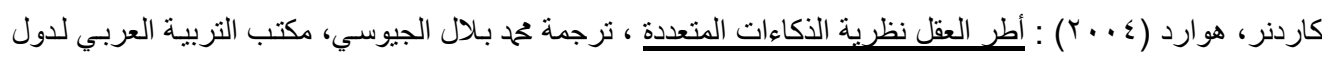
الخليج للنشر و التوزيع .

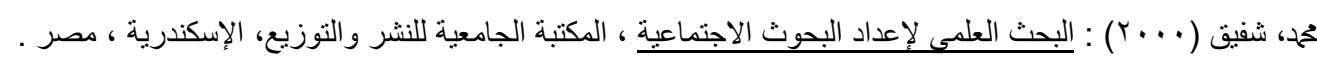

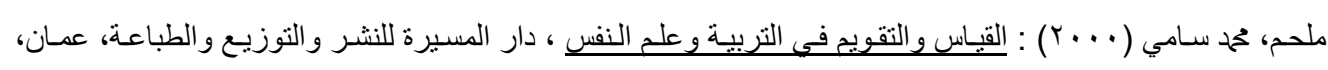
الأردن .

منصور، علي (99V1 (19) : علم النفس التربوي، طا، منشور ات جامعة دمشق، سوريا.

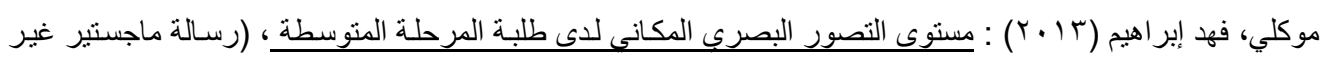

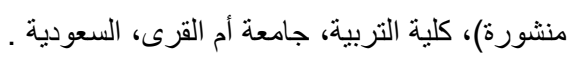

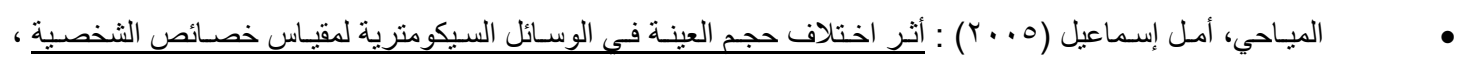

(أطروحة دكتور اه غير منشورة)، كلية التربية (أبن الرشد)، جامعة بغداد .

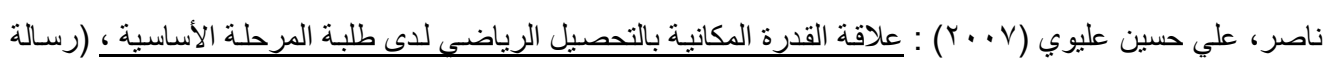

ماجستير غير منشورة)، كلية التربية (ابن رشد)، جامعة بغداد.

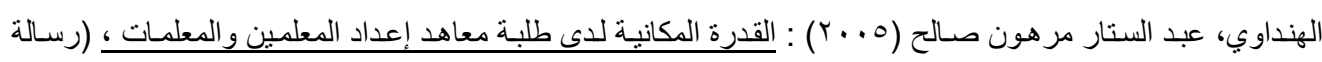

ماجستير غير منشورة)، كلية التربية (ابن الهيثم)، جامعة بغداد .

المصادر الأجنبية 
- $\quad$ Ahgina ,T.N $(Y \cdot 1 \cdot)$ : developing position study techniques in Nigerian secondary school students.

- $\quad$ Aiello, J.R. ( $Y . .1)$ : Social facilitation theory from Triplett to electronic performance monitoring, Group Dynamics, ${ }^{\circ}(r), 1 \tau r-1 \wedge \cdot$.

- $\quad$ Allen, M.\& Yen, M.( ( १९९) : Introduction to measurement theory, California, Brook Cole .

- $\quad$ Annet, M.(1910): Left right hand and brain The Right Theory, London, Caribou, Shift

- $\quad$ Aszalos, Laszlos \&Bako,Maria $\left(r_{\cdots} \ldots \varepsilon\right)$ : How can we Improve The Spatial Intelligence,,$I^{\text {th }}$ Inter national Conference on Applied Informatics $\mid$ Eger, Hungary $r Y_{-} r$ I.

- $\quad$ Bates, Tim \& Con Sough (199v): Processing Speed, Attention, and Intelligence: Effect of Spatial

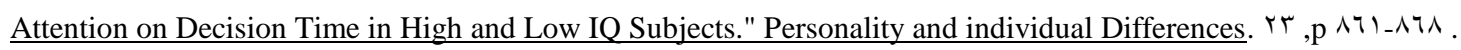

- $\quad$ Beilock,S.L.,\& Levine,S.C. $(Y \cdot \mid r)$ : Teachers' spatial anxiety relates to st-and rnd-graders'spatial learning. Mind, Brain, and Education, $\vee, 197-199$.

- Bishop,J.,( ( $9 \vee \wedge)$ :Developing students Spatial ability, Science teaching, $\Sigma^{\circ},(\wedge)$.

- $\quad$ Bosco,A \& Longoni, A.\&Vecchi, T. $(\uparrow \cdots \varepsilon)$ : Gender effects in spatial orientation :Cognitive profiles and mental strategies Applied Cognitive Psychology, 11,019_orr.

- $\quad$ Bruce, C. $(Y \cdot \mid \varepsilon)$ : Use of the I pad as a Mediator for the Development of Spatial reasoning in young Children, Proceedings of the $r \wedge_{\text {th }}$ Conference of the International Group for the Psychology of Mathematics Education. Vancouver, BC:PME.

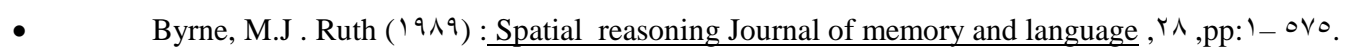

- Carrols,$J(Y \cdots 0)$ : Psychometric test as cognitive tests . anew structure of metallic,Princeton.N.J, Educational testing service, research. Bulletin, $\mathrm{V} \varepsilon$.

- $\quad$ Cheng, Y.L \& Mix,K. S.(Y.Ir) : Spatial reasoning improves children's Mathematics ability. Journal of Cognition and Development. Advance online publication .

- Clements D.H \& Battista .MT (199r) : Geometry and Spatial reasoning in D.A Grows (Ed), Handbook of research on Mathematics teaching and Learning pp( $Y$ r.- $\varepsilon \tau \varepsilon)$ rework Macmillan .

- Clements,D. H.,\& Sarama, J.(Y.11) : Early childhood teacher education: The case of geometry,Journal of Mathematics Teacher Education, $) \leqslant, \mid r r-l \leqslant \wedge$.

- $\quad$ Cohen,Paul \& Beal Carole $(Y \cdots\urcorner)$ : Image schemas and Spatial reasoning

- $\quad$ Costa,A ( $\quad$...) : A Glossary of Thinking Skill, Developing Minds A Resource Book for Teaching Thinking University of Reading Master's Thesis, U N Published, U K .

- Davis, Brent, $\left(r^{\circ}\right.$. 0$)$ : Spatial reasoning in the early years, principles, assertions , and speculation Rout ledge,New York and London

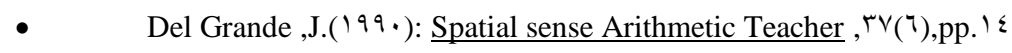

- $\quad$ Ebel, R.( ( $9 \vee r)$ : Essentials of Educational Measurement, New Jersey, Practical.

- $\quad$ Farmer, G., Verdine, B. N., Lucca, K., Davies, T., Dempsey, R., Hirsh-Pasek, K., \& Golinkoff, R. M. $(r \cdot \mid r)$ : Putting the Pieces together Spatial skills at age $r$ predict to spatial and math performance at age 0 , Presented at the Society for Research in Child Development, Seattle, WA .

- $\quad$ Ferber \& Marc, Himmelbach $(r \ldots l)$ : Spatial Awareness is a function of the temporal not the posterior lobe." Nature. $211,90 \cdot-90$ r.

\footnotetext{
- $\quad$ Forbus, Kenneth $(r \cdot 17):$ Qualitative Spatial reasoning : the Clock project Artificial Intelligence, ${ }^{\circ}$, $\varepsilon\left|V_{-} \varepsilon V\right|$.

- $\quad$ Gardener, H. ( $\quad$. $\cdots$ ):frames of mind ,New York, Bask Book.

- Ghiselli, E.E,(1911):Measurement Theory for Behavioral Sciences San Francisco, WH. Freeman, company.
} 
- $\quad$ Golledge B.Marsh M \& Bettersby $(r \cdots \wedge)$ : A conceptual framework for facilitating geospatial thinking, Annals of the Association of Aimer icon Geographers . १^( $\left(\right.$ ) $\uparrow \wedge 0_{-} r \cdot \wedge$.

- Gradinscak, Zlatko B. ( $($... $)$ : Constructional Graphics Application in Engineering Computer Graphics. Journal for Geometry and Graphics. Volume ${ }^{\circ}$, No. $r_{\text {, }} 170_{-}$। $\vee$ १.

- $\quad$ Hanlon, Adele Elizebeth $(r \cdot(\cdot)$ : Investigating The Influence of Quiche on Pre- Service Elementary Teachers Beliefs, in Concordance with Spatial and Geometric Thinking a Mixed Methods study the requirements for the Degree of Doctor of Philosophy, Oklahoma State University .

- $\quad$ Hegarty ,Mary $(Y \cdot \mathcal{~} \quad$ : The role of Spatial Thinking in Undergraduate Science Education, University of California Santa Barbara .

- James,L.,Mohler( $\quad$ $\quad$ J.^): Are view of Spatial Ability research Purdue University .

- Johnson-Laird,P.N.\&Byrne,R.M.J.( $\quad$ ( $\quad$ J ) : Deduction. Hillsdale : Erlbaum

- $\quad$ Kail ( $(9 \vee 9)$ : The Locus of sex differences in spatial ability perceptions and psychophysics.

- $\quad$ Laure, view $(r \cdots r)$ :ALogical from work for reasoning about space Laboratories intelligence Artificial , France.

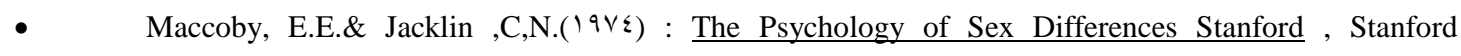
University Press .

- $\quad$ Mix, K. S.,\&Cheng, Y.-L.( $(r ., r)$ :The relation between space and math Developmental and Educational

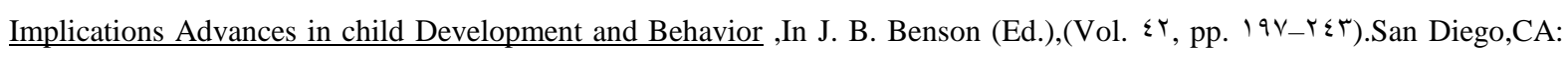
Academic Press .

- Moss,J.,\&Hawes,Z.(Y.) $\quad$ ) : Spatial reasoning: Considerations for mathematics educatorsThinking, Chicago ,IL: University of Chicago Psychometric Lab Report No. ${ }^{\circ 9}$ p.p. 1 Vo.

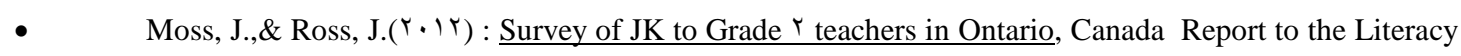
and Numeracy Secretariat of the Ministry of Education. Toronto, ON: Ontario Ministry of Education .Center co $\Lambda \cdot r \backslash \wedge, w \cdot(r \cdot r) \cdot p p \wedge r V_{-} \wedge \vee \wedge$.

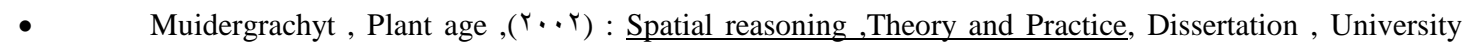
Van Amstar - dam .

- National Council of Teachers of Mathematics $\left(\gamma{ }^{7}\right)$ : Curriculum focal points for prekindergarten through grade $\wedge$ mathematics: A quest for coherence, Reston, VA: Author.

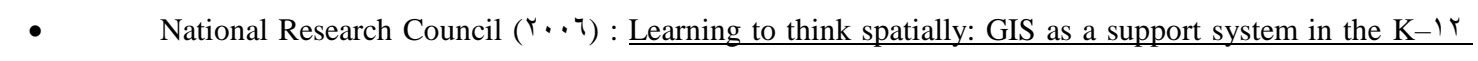
curriculum, Washington, DC: National Academic Press.

- $\quad$ Newcombe,S,Nora \& Frick, Andrea $(Y \cdot 1 \cdot)$ :Early Education for Spatial Intelligence :why, what, and how $\mathrm{LMind}$,Brain and Education Journal compilation Society and black well .

- $\quad$ Newton ,Paul\& Bristol, Helen( $(\cdot 1)$ ) : Spatial ability,Practice .Test, Copyright, Psychometric . success . com .

- $\quad$ Newton,Paul( $\left({ }^{\prime} \cdot 9\right):$ Spatial Ability Version, $:$ r.r Copyright www psychometric-success.com .

- $\quad$ Olkun $(r \cdots r)$ : Making Connections Improving Spatial Abilities With Engineering Drawing Activities International Journal of Mathematics Teaching and Learning, pp, '-1• .

- $\quad$ Pimsleur $(r \cdot 17)$ : How to improve your Spatial reasoning skills, Practice, New York: Basic Books.psychal. $\varepsilon r . p . p .191-19 \varepsilon$.

- $\quad$ Robertes \&Bell ( $r \ldots r)$ : Effect Task Mental Rotation about Imagination tow or three dimension. Vo 1) .

- $\quad$ Sarno, Emilia $(r \cdot \mid r)$ : From spatial Intelligence to spatial competences, The Results of Applied Geo

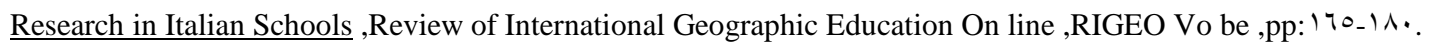

- Senan, E( $\quad . . r)$ : Improving the Spatial abilities in geometric drawing and Activities .

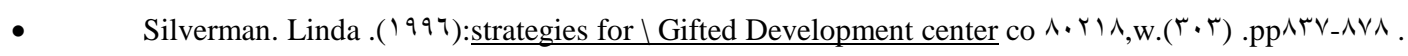


- $\quad$ Sinclair,N., \& Bruce, C. $\left(r \mid \varepsilon_{\varepsilon}\right)$ : Spatial reasoning for young learners, Proceedings of the ${ }^{r} \wedge_{\text {th }}$ Conference of the International Group for the Psychology of Mathematics Education. Vancouver, BC: PME.

- $\quad$ Stantrosck, Jihnw .w.( ( $\quad$..०) : Psychology updated, VedthJms Crow till book company USA .

- Thorndike, E.L.(19Y1):On The organization of The Intellect .psychological Review, ${ }^{\text {Y }}, 17$.

- Thurstone,L.(190.): Some primary abilities visual Thinking. Chicago ,IL: University of Chicago Psychometric Lab Report No. ${ }^{\circ 9}$ p.p. ${ }^{\text {vo }}$.

- Uttal, D. H., Meadow, N. G., Tipton, E., Hand, L. L., Alden, A. R.,Warren,C.,\& Newcombe, N. S. $(Y \cdot, r):$ The malleability of spatial skills: A meta-analysis of training studies, Psychological Bulletin, 1 rq( $(r)$, ror.

- Vander Henst, Jean Baptiste (1999): The Mental Model of theory of spatial reasoning reexamined: The role of relevance in premise order, British Journal of Psychology.

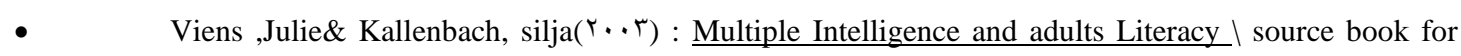
partitions $\backslash$ Teach -errs College, Columbia University New York and London .

- Wai, J., Lipinski, D., \& Benbow, C. P. ( $\quad$ ^ . १) : Spatial ability for STEM domains: Aligning over 0.

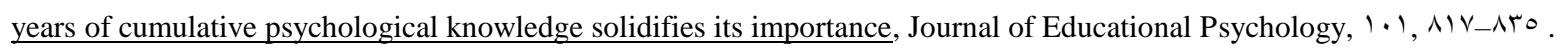

- Wang, L, (199^) : Gender Differences in Gifted Children Spatial Verbal and Quantitative Reasoning Abilities in Taiwan Taiwan: Chung Yuan Christian University .

- Wheatley,G.(199.) : Spatial sense and mathematics learning-Arithmetic Teacher, $r v,(1 \cdot-11)$.

- Wheatly,G,\&Reynolds,A. (1999): Image children Developing spatial sense Teaching children Mathematics,$\circ(\urcorner), r \vee \varepsilon_{-} r \vee \wedge$, NCTM .

- $\quad$ Yang, $(Y \ldots r)$ : Spatial ability and the impact of visualization animation on learning electrochemistry,

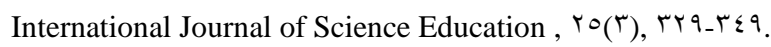

- Yuilie,C.,John( $\quad$ १^r ): Imagery, Memory and Cognition, Essays in Honor of Allan Paivio ,University of British Columbig, Hillsaye ,New Jersy.

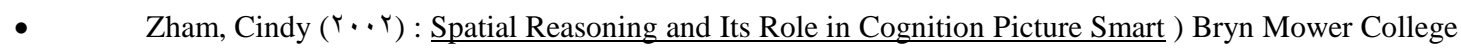

- Zwartjes,Lnc\&Lusia, Mari \& Ponert,Karl\&Buzo,Isaac $(r \cdot 10)$ : $\quad$ Literature review on spatial thinking, Gl ,Learner ,Erasmus Program me of the European Onion .

- $\quad$ http://star-manar.blogspot.com

- $\quad$ http://www.colorslab.net. 